UNIVERSIDADE DE SÃO PAULO

FACULDADE DE SAÚDE PÚBLICA

DEPARTAMENTO DE NUTRIÇÃO

\title{
DIFERENÇAS E SIMILARIDADES NA QUALIDADE DA REFEIÇÃO DO BRASIL E REINO UNIDO: QUE LIÇÕES PODEMOS APRENDER?
}

\author{
Bartira Mendes Gorgulho
}

\begin{abstract}
Tese de doutorado apresentada ao Programa de Nutrição em Saúde Pública da Faculdade de Saúde Pública da Universidade de São Paulo para obtenção do título de Doutor em Ciências.

Orientadora: Profa. Dra. Dirce Maria Lobo Marchioni

Área de Concentração: Nutrição em Saúde Pública
\end{abstract}

\section{SÃO PAULO}



DIFERENÇAS E SIMILARIDADES NA QUALIDADE DA REFEIÇÃO DO BRASIL E REINO UNIDO: QUE LIÇÕES PODEMOS APRENDER?

\author{
Bartira Mendes Gorgulho
}

Tese de doutorado apresentada ao Programa de Nutrição em Saúde Pública da Faculdade de Saúde Pública da Universidade de São Paulo para obtenção do título de Doutor em Ciências.

Orientadora: Profa. Dra. Dirce Maria Lobo Marchioni

Área de Concentração: Nutrição em Saúde Pública

VERSÃO ORIGINAL

SÃO PAULO 
É expressamente proibida a comercialização deste documento tanto na sua forma impressa como eletrônica. Sua reprodução total ou parcial é permitida exclusivamente para fins acadêmicos e científicos, desde que na reprodução figure a identificação do autor, título, instituição e ano da tese. 


\section{Dedicatória}

À minha família, Pelo apoio incondicional. 



\section{Agradecimentos}

Á Professora, orientadora e amiga, Dirce Maria Lobo Marchioni, pelos ensinamentos, respeito e confiança, pelo carinho e profissionalismo acima de tudo. Exemplo de profissional e mulher.

À Pesquisadora Gerda Pot, pela parceria e confiança.

Á Professora Flavia Mori, por estar sempre presente e disposta a ajudar, pela agradável parceria.

Ao Professor Chester, pela confiança e incentivo.

Aos Professores Alexandre Chiavegatto, Daniel Bandoni, Semíramis Domene e Neuber Segri, por todo auxilio e disponibilidade.

À Gabriela Salvate, por todo apoio e acolfimento.

À Michelle Alessandra de Castro, pelo companheirismo e colaboração desde a iniciação científica.

À Daniela Canella, pela amizade e aventuras gastronômicas, por tornar a FSP mais divertida.

Às "caminhoneiras do gelo" Valeria Baltar e Scheila Rizzato, por todas as aventuras, por me ouvirem e serem tão amigas.

À Juliana Teixeira e Roberta Santos, pela amizade, desabafos e risadas. Por todas as nossas descobertas científicas.

Ao Alexsandro, pelas ideias e discussões acadêmicas, pelo café de cada dia.

Ao Eliseu Verly Jr., por todos os momentos de risadas e descontração.

À todos os membros do GEIAS, pelo apoio e dedicação ao grupo. 
Ao Ninho, Kako e Dinda, pela amizade, por trazerem um pouco de Mogi a São Paulo. $\mathcal{A}$ Dona Lucila, Dona Hilda, Vovô e Vovó Nepomuceno, por todo carinho e acolhida.

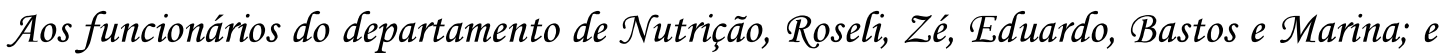
da Pós-graduação, Vânia, Alessandra, Diego, Vlisses, Cidinha e Renilda; por estarem sempre dispostos e presentes.

Aos meus irmãos Gutoso, Guimi, Vini e Juju, e aos meus sobrinhos Jobim, Lilás e Nina Simone, que eu tanto amo.

Aos meus pais, Silvia e Dimas, e tia Vânia e Meire, por estarem sempre por perto, pela compreensão e incentivo.

Ao Alexandre Sarmento, pelo companheirismo, apoio e incentivo, por estar sempre ao meu Cado.

À Fundação de Amparo à Pesquisa do Estado de São Paulo (FAPESP) e ao Conselho Nacional de Desenvolvimento Científico e Tecnológico (CSPQ) pela concessão da bolsa de Doutorado, que muito contribuiu para a realização deste estudo.

E a todos àqueles que, de alguma forma, participaram de momentos importantes em toda minha trajetória de vida. 
“De6ulhar o trigo,

Recolher cada 6ago do trigo,

Forjar no trigo o milagre do pão

E se fartar de pão..."

Milton Nascimento 

Gorgulho BM. Diferenças e similaridades na qualidade da refeição do Brasil e

Reino Unido: que lições podemos aprender? [Tese de Doutorado]. Programa de pós-graduação Nutrição em Saúde Pública, Faculdade de Saúde Pública, Universidade de São Paulo; 2016.

Introdução. Apesar de consumirmos alimentos combinados e estruturados em refeições, a maioria dos estudos ainda se concentra em nutrientes ou alimentos consumidos isoladamente. Além disso, comparar a alimentação entre países em diferentes fases de transição nutricional e epidemiológica pode fornecer informações relevantes relacionadas à prevenção da obesidade e DCNT. Objetivo. Caracterizar e comparar a qualidade nutricional da principal refeição consumida por adultos residentes no Brasil e Reino Unido. Materiais e Métodos. A primeira etapa do estudo consistiu na revisão sistemática da literatura, que subsidiou a etapa seguinte, o desenvolvimento do Main Meal Quality Index. Para comparar a qualidade das refeições utilizou-se dados dos inquéritos alimentares "Inquérito Nacional de Alimentação - INA/POF 2008/09" e "National Diet and Nutrition Survey - NDNS". Para a identificação e avaliação da qualidade da refeição utilizou-se duas diferentes abordagens: (1) abordagem híbrida, com a descrição da composição das refeições por meio da árvore de decisão de classificação, e (2) abordagem dirigida pela hipótese, através da aplicação do Main Meal Quality Index. Além disto foram analisados modelos de regressão múltipla a fim de identificar os fatores associados. Resultados. Considerando o horário de consumo e a contribuição energética, os eventos alimentares definidos como principal refeição foram o almoço, para o Brasil, e jantar, para o Reino Unido. A refeição principal brasileira (58 pontos) apresentou melhor qualidade nutricional, com maior participação de fibras e carboidratos, e menor teor de gorduras total e saturada, e densidade energética. No entanto, a principal refeição do Reino Unido (54 pontos) foi composta por mais frutas, verduras e legumes. Os ingredientes culinários, como arroz e feijão, foram classificados pelo algoritmo como componentes característicos da refeição brasileira, enquanto os itens de fast food, como batatas fritas, sanduíches e bebidas açucaradas, foram classificados como refeições Britânicas. No Brasil, o escore final do indicador associou-se positivamente com a idade, e negativamente com o gênero, energia consumida, estado nutricional e renda familiar; enquanto que, no Reino Unido, o indicador associou-se apenas com a idade (positivamente). Conclusão. Embora a principal refeição consumida no Brasil, quando comparada ao Reino Unido, apresente melhor qualidade e composição, as refeições consumidas em ambos os países estão aquém do recomendado.

Descritores: refeição, qualidade da dieta, padrão alimentar, Brasil, Reino Unido 



\section{Gorgulho BM. Similarities and differences of meal quality between Brazil and}

United Kingdom: what lessons can we learn? [Doctoral thesis]. Postgraduate program in Public Health Nutrition, School of Public Health, University of Sao Paulo; 2016.

Introduction. Although individuals consume foods combined and structured at meals, most authors still have studied nutrient or single food. Furthermore, compare countries in different stages of nutritional and epidemiological transition can provide relevant information related to the prevention of obesity and NCDs. Objective. To characterize and compare the nutritional quality of meals consumed by adults living in Brazil and UK. Subjects and methods. The first stage of the study consisted of a systematic review of the literature, which subsidized the next step, the development of the Main Meal Quality Index. Data from food surveys "National Survey of Food INA / HBS 2008/09" and "National Diet and Nutrition Survey - NDNS" were used to analyzed and compare the main meals quality. Two different approaches for the identification and evaluation of the main meal pattern were used: (1) hybrid approach, to evaluate of the meal patters using data reduction techniques; and (2) hypothesis-driven approach, with the Main Meal Quality Index. Then, regression models were applied to analyzed associated sociodemographic factors. Results. Considering time slot and energy content, the eating events defined as main meal were lunch, for Brazil, and dinner, for UK. Brazilian main meal (58 points) had better nutritional quality, with greater participation of fiber and carbohydrates, and lower content of total and saturated fat, and energy density. However, the main meal consumed in UK (54 points) had more fruits and vegetables. Cooking ingredients, such as rice and beans, were classified as characteristic components of a Brazilian meal, while fast food items, like chips, sandwiches and sugary drinks, were classified as a British meal. In Brazil, the final score was positively associated with age, and negatively correlated with gender, energy consumption, nutritional status and family income; whereas, in the United Kingdom, the indicator is only associated with age (positively). Conclusion. Although Brazilian main meal, when compared with UK main meal, provide best quality and composition, meals consumed in both countries need improvement.

Keywords: meals, dietary quality, dietary pattern, Brazil, United Kingdom. 



\section{ÍNDICE}

LISTA DE FIGURAS ___ 8

LISTA DE TABELAS _ _ 9

LISTA DE ABREVIATURAS

1. INTRODUÇÃO __ 14

1.1. OBESIDADE E AS DOENÇAS CRÔNICAS NÃO TRANSMISSÍVEIS ___ 14

1.2. PADRÃO ALIMENTAR__ 16

1.3. REFEIÇÕES _ 19

1.4. ÍNDICES DIETÉTICOS __ 21

1.5. INQUÉRITOS ALIMENTARES___ 24

2. JUSTIFICATIVA _ 26

3. OBJETIVO _ 27

3.1. OBJETIVO GERAL _ 27

3.2. OBJETIVOS ESPECÍFICOS__ 27

4. MATERIAL E MÉTODOS

4.1. CONTEXTUALIZAÇÃO __ 27

4.1.1. ETAPA 1 - REVISÃO SISTEMÁTICA _ 28

4.1.2. ETAPA 2 - DESENVOLVIMENTO DO INDICADOR _ 28

4.1.3. ETAPA 3 - AVALIAÇÃO E COMPARAÇÃO DA REFEIÇÃO __ 29

4.2. DELINEAMENTO DO ESTUDO___ 30

4.3. CASUÍSTICA _ 30

4.3.1. ÍNQUERITO DE SAÚDE DE SÃO PAULO - ISA-CAPITAL $2008 \_30$

4.3.2. INQUÉRITO NACIONAL DE ALIMENTAÇÃO - INA/POF 2008/09__ 31

4.3.3. NATIONAL DIET AND NUTRITION SURVEY - NDNS ___ 32

4.3.4. COLETA DOS DADOS _ 34

4.3.5. INQUÉRITO ALIMENTAR __ 34 
4.4. ANÁLISE DOS DADOS 35

4.4.1. ABORDAGEM HÍBRIDA 35

4.4.2. ANÁLISE ESTATÍSTICA 38

4.5. ASPECTOS ÉTICOS 39

5. RESULTADO DE DISCUSSÃO 39

5.1. REVISÃO SISTEMÁTICA 39

5.1.1. MANUSCRITO 1 39

5.2. DESENVOLVIMENTO DO INDICADOR 65

5.2.1. MANUSCRITO 2 65

5.3. AVALIAÇÃO E COMPARAÇÃO DA REFEIÇÃO 83

5.3.1. MANUSCRITO 3 87

5.3.2. MANUSCRITO 4 109

6. CONSIDERAÇÕES FINAIS 128

7. REFERÊNCIAS 131 ANEXOS 141

ANEXO I - PROTOCOLO PARA REVISÃO SISTEMÁTICA 142 ANEXO II - VALIDAÇÃO MMQI NO UK (NDNS) 147

ANEXO III - VALIDAÇÃO MMQI BRASIL (INA/POF 2008/09) 156

ANEXO IV - COMITE DE ÉTICA EM PESQUISA 157 ANEXO V - CURRÍCULO LATTES 158 


\section{LISTA DE FIGURAS}

Figura 1 - Países que compõem o Reino Unido.

Figura 2 - Exemplo de Árvore de Decisão

Manuscrito 1:

Figura 1 - Flow diagram illustrating the screening process of eligible studies.

Manuscrito 2:

Figura 1 - Average score of the MMQI components by Brazilian regions. Brazil, 2008-2009.

Manuscrito 3

Figura 1 - Decision tree classification of main meal composition in Brazil and UK. Brazil, 2008/09, and UK, 2008/09-2011/12. 


\section{LISTA DE TABELAS}

Manuscrito 1:

Tabela 1 - Inclusion and exclusion criteria used for the present review.

Tabela 2 - Findings from studies included in the systematic review.

Tabela 3 - Indices included in the systematic review.

Manuscrito 2:

Tabela 1 - Main Meal Qulity Index components and standards for scoring.

Tabela 2 - Characteristics of the individuals and the MMQI score. Sao Paulo, Brazil (2008).

Tabela 3 - Association between MMQI and nutrients consumed at lunch. Sao Paulo, Brazil (2008).

Tabela 4 - Association between MMQI and revised version of the Healthy Eating Index for the Brazilian population (HEI-B). Sao Paulo, Brazil (2008).

Manuscrito 3:

Tabela 1 - Subjects caracteristics. Brazil, 2008/09, and UK, 2008/09-2011/12.

Tabela 2 - The MMQI and its components score. Brazil, 2008/09, and UK, 2008/09$2011 / 12$.

Tabela 3 - Main meal quality and associated factors. Brazil, 2008/09, and UK, 2008/09-2011/12.

Manuscrito 4:

Tabela 1 - MMQI components and score criteria.

Tabela 2 - Characteristics of population studied and lunch meal quality. Brazil, 2008-2009.

Tabela 3 - Table 3. Brazilian meal quality and MMQI components score. Brazil, 2008-2009.

Tabela 4 - Fatores associados a qualidade do almoço dos brasileiros. Brasil, 20082009. 


\section{LISTA DE ABREVIATURAS}

AMPM - Automated Multiple-Pass Method

BHEI-R - Brazilian Health Index Revised

CGAN- Coordenação Geral de Alimentação e Nutrição

CNPQ - Conselho Nacional de Desenvolvimento Científico e Tecnológico

DCNT - Doenças Crônicas não Transmissíveis

FAPESP - Fundação de Amparo à Pesquisa do Estado de São Paulo

HEI - Health Eating Index

IBGE - Instituto Brasileiro de Geografia e Estatística

IQD-R - Índice de Qualidade da Dieta Revisado

INA - Inquérito Nacional de Alimentação

ISA - Inquérito de Saúde de São Paulo

MS - Ministério da Saúde

MMQI - Main Meal Quality Index

NDS - Nutrition Data System for Research

NDNS - National Diet and Nutrition Survey

OMS - Organização Mundial da Saúde

PNAD - Pesquisa Nacional por Amostra de Domicílios

PNS - Pesquisa Nacional de Saúde

POF - Pesquisa de Orçamentos Familiares

$\mathrm{R} 24 \mathrm{~h}$ - Recordatório alimentar de 24h

TCLE - Termo de Consentimento Livre e Esclarecido

USDA - United States Department of Agriculture

WHO - World Health Organization

WCRF - World Cancer Research Foundation 



\section{APRESENTAÇÃ̃o}

Esta tese está estruturada em formato de artigos científicos, sob o respaldo das diretrizes promulgadas pela Comissão de Pós-Graduação da Faculdade de Saúde Pública da Universidade de São Paulo em sua sessão 9ª/2008 de 05/06/2008, e atende às normas de apresentação das dissertações contidas no Guia de Apresentação de Teses desta instituição.

A tese está organizada nas seguintes seções: (1) Introdução, que aborda o conhecimento existente sobre a obesidade e o desenvolvimento da doenças crônicas não transmissíveis, a análise de padrões alimentares, as características de estudos que abordam refeições, os indicadores de qualidade da dieta, e o papel dos inquéritos alimentares; (2) Justificativa, destacando a relevância da investigação; (3) Objetivos, em que são descritos os propósitos do estudo; (4) Métodos, que contempla a contextualização, delineamento, casuística, análise dos dados e aspectos éticos; (5) Resultados e Discussão, que inclui os manuscritos desenvolvidos, contemplando as etapas de revisão sistemática da literatura sobre indicadores de qualidade da refeição já existentes, o desenvolvimento e validação do Main Meal Quality Index, e a avaliação e comparação da qualidade da principal refeição consumida no Brasil e Reino Unido, bem como a identificação de seus fatores associados; e, por fim, (5) Considerações Finais, que sumariza os principais achados do estudo. 



\section{INTRODUÇÃO}

Apesar de consumirmos alimentos combinados e estruturados em refeições, a maioria dos estudos ainda se concentra em nutrientes ou alimentos consumidos isoladamente. É crescente número de estudos analisando o hábito de pular refeições, realiza-las em horários regrados ou alternados, ou consumi-las sozinhos ou acompanhados, em casa ou na rua; no entanto, ainda são escassos os estudos que se propõe a avaliar a composição das refeições e seu papel na qualidade global da dieta e impacto na saúde, bem como seus condicionantes (Leech et al, 2015).

Em um cenário epidemiológico global, com crescentes taxas de obesidade, reconhecido fator de risco de inúmeras doenças crônicas, considera-se a dieta como um importante fator de risco modificável, e, portanto, que tem sido objeto de guias e recomendações voltadas para a população. Se, em um primeiro momento, estes guias baseavam-se em nutrientes, verificou-se uma gradual mudança para enfase no consumo de alimentos, e, mais recentemente, na estrutura de refeições. Além disso, observa-se contínua elevação das taxas de obesidade em países em diferentes fases de transição nutricional e epidemiológica. Nesse sentido, comparar a estrutura e qualidade de refeições pode fornecer informações relevantes relacionadas à prevenção da obesidade e consequentemente, das DCNT.

\subsection{OBESIDADE E AS DOENÇAS CRÔNICAS NÃO TRANSMISSÍVEIS}

As doenças crônicas não transmissíveis (DCNT) são as principais causas de mortalidade e incapacidade no mundo (WHO, 2013), sendo responsáveis por 30\% dos 58 milhões de óbitos em 2005 (WHO, 2007). Hipercolesterolemia, diabetes 
mellitus, tabagismo, hipertensão e, com destaque, a obesidade tem sido reconhecidos como os principais fatores de risco para doenças cardiovasculares (Gravina-Taddei et al., 2005) que, no Brasil, estão entre as principais causas de morte em todas as regiões, respondendo por 20\% dos óbitos em indivíduos acima dos 30 anos (Mansurt e Favarato, 2012).

Uma vez considerado um problema apenas em países desenvolvidos, o sobrepeso e a obesidade apresentam rápida ascensão em países de baixa e média renda. $\mathrm{O}$ excesso de peso e a obesidade são encontrados com grande frequência, a partir de cinco anos de idade, em todos os grupos de renda e em todas as regiões brasileiras (IBGE, 2011). A avaliação do estado nutricional dos jovens de 10 a 19 anos revela que no Brasil o aumento de peso em adolescentes e adultos foi contínuo nos últimos 34 anos. Em 2008, a prevalência de excesso de peso no Brasil foi de aproximadamente $50 \%$, enquanto que em países como Estados Unidos e Reino Unido ultrapassou os 60\% (WHO, 2013). Na Grã-Bretanha, no período de 1980 a 2002, a prevalência de obesidade (IMC $>30 \mathrm{~kg} / \mathrm{m}^{2}$ ) em adultos triplicou, passando de $6 \%$ e $8 \%$ para $23 \%$ e $25 \%$, respectivamente entre os homens e as mulheres (Rennie e Jebb, 2005). No entanto, são observadas diferenças nas concentrações dos casos de obesidade de acordo com os estágios de desenvolvimento econômico de cada país: enquanto em países desenvolvidos a prevalência de obesidade é mais elevada entre os indivíduos de menor renda e moradores da zona rural, em países em desenvolvimento há elevação nas taxas de obesidade na zona urbana, em indivíduos de melhor renda (Popkin et al., 2011). 
A obesidade é uma resposta natural dos indivíduos ao ambiente obesogênico, que, por sua vez, resulta do desenvolvimento industrial frente ao momento político e econômico de cada nação. Neste contexto, o crescimento econômico é especialmente importante para os países de menor renda, permitindo a mudança da pobreza à prosperidade econômica. Já para países de maior renda, o crescimento econômico pode não significar melhora na qualidade de vida, uma vez que a população passa a ter acesso a todo o tipo de produto (Egger e Swinburn, 2010). As mudanças tecnológicas que acompanham o crescimento econômico acabam por tornar os alimentos mais calóricos e baratos, conduzindo a população a um consumo alimentar excessivo (Culter et al., 2010; Finkelstein et al., 2005; Philipson et al., 2003).

\subsection{PADRÃO ALIMENTAR}

A ascensão do sobrepeso e da obesidade está associada com as mudanças nos padrões alimentares: aumento do consumo de gorduras, excesso de açúcar, e consumo insuficiente de frutas e hortaliças, levando a um aumento da densidade energética das dietas (Gorgulho et al., 2013; Marchioni et al., 2012; Bigio et al., 2011). A Estratégia Global para Alimentação, Atividade Física e Saúde da Organização Mundial da Saúde destaca a necessidade de adequação dos padrões alimentares em todo o mundo (WHO, 2002). Apesar das diferenças culturais, assim como no Brasil, as recomendações nutricionais atuais estabelecidas pelo Ministério da Saúde na Inglaterra e País de Gales, pela Agência de Saúde na Irlanda do Norte, e pelo Governo escocês preconizam o consumo de grãos integrais, frutas, verduras e legumes, acompanhados da redução dos alimentos gordurosos e açucarados (Food Standards Agency, 2010; Public Health Agency, 2010; Scottish Government, 2006). 
No Brasil, além do consumo inadequado de micronutrientes, observa-se consumo insuficiente de fibras por $68 \%$ da população e consumo excessivo de gorduras saturadas e açúcar por $82 \%$ e $61 \%$ dos indivíduos, respectivamente (IBGE, 2011). No estudo ISA - Capital 2003, o consumo excessivo de açúcar de adição foi identificado em $70 \%$ dos adolescentes, em $38 \%$ dos adultos e em $25 \%$ dos idosos (Colucci et al., 2011), e esteve associado ao elevado consumo de refrigerantes, sucos industrializados, achocolatado em pó e biscoitos recheados (Bueno et al., 2012). Em contrapartida, na mesma população, a ingestão diária de frutas, legumes e verduras mostra-se abaixo dos níveis recomendados pelo Ministério da Saúde (400g) para mais de $90 \%$ da população (Bigio et al., 2011).

No Reino Unido, os primeiros resultados do estudo National Diet and Nutrition Survey, mostraram que os alimentos com maior consumo médio entre os homens adultos eram os chás e cafés, vegetais não crus (incluindo enlatados), massas, arroz branco e outros cereais refinados (incluindo pizzas e salgados), refrigerantes e pães brancos. Já entre as mulheres adultas, os alimentos que apresentaram maior consumo médio eram os chás e cafés, vegetais não crus (incluindo enlatados), frutas, leite semidesnatado e massas, arroz branco e outros cereais refinados (incluindo pizzas e salgados) (Whitton et al., 2011).

O aumento no consumo alimentar fora do lar e o aumento do consumo de alimentos processados, fruto das mudanças sociais, econômicas e culturais ocorridos nas últimas décadas, são alguns dos comportamentos alimentares descritos na literatura como responsáveis pela qualidade nutricional das dietas aquém do 
recomendado (Bes-Rastrollo et al., 2010; Ziegler et al., 2006; Abreu et al., 2005; Kant e Graubard, 2004; Kearney et al., 2001; Lin et al., 1999).

Sichieri et al. (2012), ao compararem a alimentação dentro e fora do lar, observaram que cerca de 40 a $60 \%$ da energia provenientes das bebidas alcoólicas, refrigerantes, salgados, sanduiches e pizzas eram consumidas fora do lar. Este cenário corrobora ao encontrado por Orfanos et al. (2010) em 10 países da Europa, onde alimentos como açúcares e doces; chá e cafés e bebidas alcoólicas apresentaram maior contribuição para as calorias provenientes da alimentação fora do lar.

No Brasil, diferentemente do Reino Unido, apesar do crescente aumento da aquisição de alimentos processados e prontos para o consumo nos últimos 30 anos (Monteiro et al., 2010), a dieta ainda é composta principalmente por alimentos minimamente processados e ingredientes culinários (Mourabac et al., 2013). Em 2008, os alimentos mais consumidos pela população brasileira foram: arroz (84\%), café $(79 \%)$, feijão (73\%), pão de sal $(63 \%)$, carne bovina $(49 \%)$, sucos e refrescos (40\%) e refrigerantes (23\%) (Souza et al., 2013).

Marchioni et al. (2011), considerando os dados de aquisição de alimentos fornecidos pela Pesquisa de Orçamentos Familiares de 2002, descreveram dois padrões alimentares brasileiros: o primeiro, chamado "dual", caracterizou-se por produtos lácteos, frutas, suco de frutas, legumes, carne processada, refrigerantes, doces, pão e margarina, com correlações inversas com alimentos tradicionalmente brasileiros. Em contrapartida, o segundo padrão, "tradicional", foi caracterizado por grupos de alimentos geralmente utilizados em preparação doméstica e culinária de 
pratos tradicionais, como arroz, feijão, mandioca, farinha, leite e açúcar. No Reino Unido, a mesma análise foi utilizada para identificar o padrão alimentar de adultos de baixa renda, obtendo-se, no entanto, quatro diferentes padrões: (1) "fast food" (2), "saúde consciente", (3) "tradicional", e (4) "doce". Sendo o padrão "fast food" capaz de explicar a maior proporção da variância (Hamer e Mishra, 2010).

A relação entre consumo alimentar e saúde é indiscutível. No entanto, tradicionalmente, a maioria dos estudos ainda se concentra em analisar isoladamente o consumo de nutrientes ou alimentos. Embora não haja consenso na literatura na caracterização das refeições, há muitos programas institucionais (p.ex. "Cartilha Meu prato saudável"- INCOR; "Health Eating Plate" - Harvard; "Eat well Plate" - NHS) que promovem o consumo de refeições saudáveis.

\subsection{REFEIÇÕES}

A palavra "refeição" pode referir-se tanto a um evento, o momento em que se alimenta, como a um produto, do que se alimenta. Em outras palavras, o consumo de alimentos é parte de um evento estruturado que segue regras de combinação de alimentos (Meiselman, 2008).

As refeições são importantes não só para fornecer nutrientes e energia, mas também como uma instituição cultural e social (Rozin, 2005). Desta forma, ao observar um evento, definindo uma refeição, diferentes aspectos devem ser considerados, como o horário, a contribuição energética, a interação social e o número de alimentos combinados (Meiselman, 2008; Oltersdorf et al, 1999). 
Observar as combinações de alimentos em cada evento permite compreender a complexidade e imprevisibilidade da dieta, superarando limitações do estudo isolado de nutrientes e alimentos (Hoffmann, 2003). A escolha dos alimentos que serão consumidos em um mesmo evento ocorre de maneira complexa, sendo modulada por diversos determinantes, tais como as condições sociodemográficas, sexo, faixa etária, estado nutricional, estrutura familiar, local de consumo e preparo dos alimentos, e hábitos culturais (Wang et al., 2012; Costa et al., 2005; Fjellström, 2004). O café da manhã, almoço e jantar, por exemplo, apesar de característicos de diversos países, podem apresentar diferentes estruturas e significados. Se em algumas regiões o almoço ou o café da manhã é considerado a principal refeição, em outros, o jantar representará este papel (Meiselman, 2008).

Apesar de existirem estudos caracterizando as refeições ofertadas por unidades institucionais de alimentação e nutrição (Patterson et al., 2012; Gorgulho et al., 2010; Bandoni e Jaime, 2008) e restaurantes comerciais (Abreu et al., 2005), são escassos os trabalhos com dados representativos, que reflitam o padrão habitual das refeições consumidas por populações. Alguns estudos descrevem a omissão de determinadas refeições (Kulovitz et al., 2013; Ma et al., 2003; Fabry et al., 1964) e mostram a importância de realizar a refeição em família (Offer, 2013; Skafida, 2013; Berge et al., 2012;) ou com amigos (Sommer et al., 2013; Berge et al., 2012; Larson et al., 2009), mas poucos avaliam a combinação e a qualidade nutricional dos alimentos consumidos em um mesmo evento.

Kant et al. (2012), ao observarem o consumo de bebidas durante as refeições, encontraram diferenças nutricionais quantitativas e qualitativas nos alimentos 
selecionados para o consumo. Os norte-americanos, que apresentaram maior ingestão de energia a partir de bebidas, relataram consumir alimentos com maior densidade energética, ricos em gordura total, gordura saturada, açúcar e sódio (Kant et al., 2012).

No Brasil, Gorgulho et al. (2013), ao analisarem a qualidade nutricional das refeições consumidas por moradores do município de São Paulo, verificaram que as três refeições principais (café da manhã, almoço e jantar) consumidas por adolescentes, adultos e idosos estavam aquém das recomendações, independente do local de consumo.

\section{4. ÍNDICES DIETÉTICOS}

Ao analisar a alimentação, é importante obter-se o máximo de informações, buscando-se considerar as evidências científicas atuais para um padrão de alimentação que colabore na prevenção das DCNT, abrangendo os diversos aspectos de sua composição, quer seja na ingestão de nutrientes ou no consumo de alimentos e grupos de alimentos (Kant, 1996; Haines et al., 1999). Dentro dessa perspectiva, na década de 90, surgiram estudos que desenvolveram índices com objetivo de criar um único instrumento simples para refletir a qualidade da alimentação, permitindo acompanhar as mudanças no padrão alimentar ao longo do tempo (Cervato e Vieira, 2003; Kant, 1996).

Os índices para avaliação da alimentação consideram a ingestão de alimentos e nutrientes simultaneamente, permitindo uma avaliação indireta de componentes da dieta sem reduzir a avaliação a um único item. Assim, eles procuram comparar a 
ingestão de determinados nutrientes e alimentos a um determinado padrão, estabelecendo uma pontuação que permite classificar a alimentação (Kant, 1996; Kennedy et al., 1995).

O primeiro índice dietético desenvolvido foi o Diet Quality Index, criado em 1994 por Kant, com o objetivo de desenvolver um instrumento de medida da qualidade global da dieta que refletisse um gradiente de risco para muitas doenças crônicas relacionadas com a alimentação (Patterson et al., 1994). Ao longo do tempo o Diet Quality Index sofreu modificações, dando origem ao Healthy Eating Index (Kennedy et al., 1995), utilizado pelo Departamento de Agricultura dos Estados Unidos. Entretanto, apesar da revisão do instrumento nos anos de 2005 e 2012, estudos demonstraram que a utilização de Índices Dietéticos em outros países requer certas adaptações (Kennedy et al., 1995).

No Brasil, Fisberg et al. (2004) adaptaram e validaram para a população brasileira o Healthy Eating Index (HEI), originando o Índice de Qualidade da Dieta (IQD), que avalia uma combinação de diferentes tipos de alimentos, nutrientes e constituintes da dieta em relação às recomendações dietéticas e/ou desfechos de saúde. Com a publicação do Guia Alimentar para a População Brasileira em 2006, e frente à necessidade de revisão do IQD, Previdelli et al. (2011) desenvolveram e validaram o Índice de Qualidade da Dieta Revisado (IQD-R).

Além das adaptações do HEI, existem outros indicadores propostos para avaliar a qualidade da dieta. Em 2013, por exemplo, Caivano e Domene propuseram um índice de qualidade da dieta para escolhas alimentares saudáveis dos adultos 
brasileiros, o Diet Quality Index - Digital Food Guide (DQI-DFG). Este indicador é composto por 12 componentes divididos entre itens que devem ser consumidos com moderação e itens que devem ser consumidos em quantidades adequadas, ajustados por energia, e que resulta em um escore de zero a 100 pontos.

Tais instrumentos avaliam a ingestão de nutrientes e alimentos e são baseados nos princípios de proporcionalidade, moderação e variedade da dieta. No entanto, apesar da atenção que têm suscitado a avaliação de padrões de dieta, a literatura ainda é escassa em relação a padrões de refeições e, diferente das várias propostas de índices para avaliação global da dieta, há uma lacuna em relação a propostas de indicadores de qualidade de refeição.

Bandoni e Jaime (2008), com base nas recomendações da OMS e Ministério da Saúde brasileiro, propuseram o Índice de Qualidade da Refeição (IQR) com objetivo de avaliar refeições ofertadas em serviços de alimentação, composto por cinco componentes que variam entre zero e 20 pontos cada; a saber: adequação na oferta de legumes, verduras e frutas; oferta de carboidratos; oferta de gordura total; oferta de gordura saturada e variabilidade do cardápio. Entretanto, embora o indicador permita uma avaliação indireta da refeição sem reduzir a avaliação a um único item, dois de seus componentes (oferta de carboidratos e oferta de gordura total) interferem um no outro, uma vez que são somas de porcentagens (Gorgulho et al., 2010).

Lassen et al. (2010) também propuseram um índice para refeições, chamado Healthy Meal Index, baseados nas recomendações dinamarquesas para a alimentação 
saudável e na OMS. Esse índice, uma combinação de três componentes (oferta de frutas, verduras e legumes; oferta de cereais integrais; oferta de gorduras totais), como reconhecido pelos próprios autores, acaba não considerando outras importantes recomendações, como a oferta de sódio.

Considerando a dificuldade para avaliação da qualidade nutricional de refeições e seu impacto para a qualidade da dieta, os estudos de comparação de refeições em diferentes países são escassos. No entanto, comparar a alimentação entre países em diferentes fases de transição nutricional e epidemiológica poderia fornecer informações relevantes relacionadas à prevenção da obesidade e DCNT.

\subsection{INQUÉRITOS ALIMENTARES}

O consumo alimentar está entre os principais fatores de risco modificáveis para o desenvolvimento da obesidade e outras doenças crônicas não transmissíveis, e sua estimativa pode contribuir para o planejamento de políticas públicas de alimentação e nutrição (Wotwki, 2003). Neste contexto, destacam-se os inquéritos alimentares, estudos transversais, representativos da população, que possibilitam conhecer os hábitos alimentares, seus fatores de risco associados e determinantes sóciodemográficos, fornecendo informações que auxiliam a embasar o planejamento, monitoramento e gerenciamento de programas para melhoria dos padrões de consumo alimentar e de estado nutricional da população (Brasil, 2008).

A vantagem deste tipo de pesquisa é a obtenção de informações básicas que nortearão avaliações periódicas posteriores. Entretanto, o alto custo e o desgastante trabalho operacional são limitações que, muitas vezes, acabam reduzindo a 
periodicidade e o tamanho das amostras, dificultando o diagnóstico preciso de problemas nutricionais.

Contudo, inquéritos populacionais em alimentação e nutrição estão entre as estratégias de vigilância epidemiológica utilizadas pela Coordenação Geral de Alimentação e Nutrição (CGAN) do Ministério da Saúde (MS) para implementação da vigilância alimentar e nutricional no Brasil (Coutinho et al., 2009). A realização periódica de pesquisas de avaliação do consumo alimentar propicia a formação de séries temporais, essenciais para a identificação de mudanças no padrão dietético por estratos socioeconômicos e áreas geográficas, a fim de, posteriormente, formular políticas nutricionais em saúde pública (Monteiro et al., 2000). Ademais, dados populacionais representativos, além de permitirem o acompanhamento da população ao alongo do tempo, permitem a comparação com outros grupos populacionais, facilitando a identificação de práticas alimentares de risco à saúde.

Entre os principais inquéritos de saúde com dados sociodemográficos e de consumo alimentar realizados no Brasil estão: o "Inquérito de Saúde de São Paulo" (estudo ISA-Capital) (Cesar et al, 2005); o "Inquérito Nacional de Alimentação" (INA/POF 2008-09) (IBGE, 2010), e a "Pesquisa Nacional de Saúde" (PNS) (Szwarcwald et al, 2014). O ISA-Capital é um estudo representativo do município de São Paulo, e o primeiro inquérito brasileiro a ter dados representativos de consumo alimentar com biomarcadores e perfil metabólico. Já o INA, bloco de consumo alimentar da Pesquisa de Orçamentos Familiares, foi o primeiro inquérito nacional com duas medidas de registro alimentar representativos de todas as regiões brasileiras. Enquanto que a PNS, por sua vez, foi o primeiro inquérito nacional a 
combinar dados de consumo alimentar e material bioquímico representativos da população brasileira.

Entre os inquéritos alimentares realizados em outros países destacam-se: o "National Diet and Nutrition Survey" (NDNS) (DH, 2013), realizado no reino Unido; e o "National Health and Nutrition Examination Survey" (NHANES), realizado nos EUA (Ahluwalia et al, 2016). Ambos os estudos são periódicos e, além de dados de consumo alimentar, apresentam biomarcadores.

\section{JUSTIFICATIVA}

A alimentação é considerada pela Organização Mundial da Saúde um dos principais fatores de risco modificáveis para DCNT, ressaltando a importância do entendimento dos hábitos alimentares e seus determinantes no atual cenário epidemiológico. Entretanto, são poucos os estudos que se propõem a avaliar, em nível populacional, as características das refeições, bem como seu impacto na qualidade global da dieta. Assim, considerando suas diferenças diante da transição nutricional e desenvolvimento econômico, bem como as similaridades guardadas entre seus inquéritos alimentares, ao investigar e comparar as características nutricionais das refeições no Brasil e Reino Unido, proposta deste trabalho, espera-se contribuir preenchendo uma lacuna do conhecimento, de forma a oferecer subsídios para o planejamento e implementação de ações de promoção da alimentação saudável e combate a obesidade e as doenças crônicas não transmissíveis.

Para tanto, levantaram-se as seguintes hipóteses: (1) que os adultos residentes no Brasil e no Reino Unido ainda apresentam hábitos alimentares diferentes; e (2) 
que, ao observar os hábitos alimentares do Reino Unido, o Brasil pode conter o avanço do sobrepeso e da obesidade, afim de não alcançar as mesmas prevalências alarmes.

\section{OBJETIVO}

\subsection{OBJETIVO GERAL}

Caracterizar e comparar a qualidade nutricional da refeição consumida por adultos residentes no Brasil e Reino Unido.

\subsection{OBJETIVOS ESPECÍFICOS}

- Revisar os índices de qualidade nutricional da refeição já existentes;

- Propor um índice de qualidade da refeição para uso em estudos epidemiológicos;

- Avaliar a qualidade da refeição consumida por adultos residentes no Brasil e Reino Unido;

- Descrever as diferenças entre a composição da refeição consumida por adultos residentes no Brasil e Reino Unido;

- Descrever a qualidade da refeição consumida nas grandes regiões brasileiras e seus determinantes.

\section{MATERIAL E MÉTODOS}

\subsection{CONTEXTUALIZAÇÃO}

O presente projeto teve três etapas: 1) revisão sistemática da literatura sobre índices de qualidade de refeição; 2) desenvolvimento e proposição de um indicador 
para avaliação da qualidade da principal refeição, o Main Meal Quality Index; e 3) avaliação e comparação da principal refeição consumida no Brasil e Reino Unido, a partir de dados das pesquisas intituladas "Inquérito Nacional de Alimentação INA/POF 2008/09" conduzida no Brasil e "National Diet and Nutrition Survey NDNS", conduzida no Reino Unido.

\subsubsection{ETAPA 1 - REVISÃO SISTEMÁTICA}

Realizou-se revisão sistemática da literatura sobre instrumentos de aferição e avaliação da qualidade global de refeições. O protocolo utilizado encontra-se no Anexo I, e os resultados encontrados são descritos no manuscrito 1 da seção "Resultados e Discussão". A busca por artigos científicos relacionados ao tema ocorreu em bases de dados eletrônicas, em periódicos indexados, de acordo com unitermos predefinidos.

\subsubsection{ETAPA 2 - DESENVOLVIMENTO DO INDICADOR}

Com base nas recomendações nutricionais estabelecidas pela Organização Mundial da Saúde (WHO 2003) e pelo World Cancer Research Fund (WCRF 2007), e considerando os resultados obtidos com a revisão sistemática da literatura, foi proposto o Main Meal Quality Index (MMQI), indicador desenvolvido e validado para avaliar a qualidade da principal refeição.

Inicialmente o MMQI foi desenvolvido utilizando-se os dados do Inquérito de Saúde de São Paulo (ISA-2008), levando-se em conta que este inquérito dispõe de dados bioquímicos e biomarcadores do consumo alimentar. Posteriormente o 
indicador foi testado para uso no Brasil (toda extensão territorial) e Reino Unido, utilizando-se dados do Inquérito Nacional de Alimentação (INA/POF 2008/09) e do National Diet and Nutrition Survey (NDNS).

Em todos os estudos o MMQI apresentou desempenho satisfatório. Seu desenvolvimento e validação no estudo ISA-2008 estão descritos no manuscrito 2 da seção "Resultados e Discussão", já a validação no INA e no NDNS estão disponíveis nos Anexos II e III.

Os dados de consumo alimentar do estudo ISA- 2008 provêm da pesquisa intitulada "Fatores dietéticos, homocisteína, polimorfismos do gene MTHFR e risco cardiovascular em adultos e idosos: estudo de base populacional", estudo transversal, de base populacional, financiado pelo CNPq, processo no. 461176/2008-0, edital MCT/CNPq 14/2008, Universal e pela Fundação de Amparo a Pesquisa de São Paulo (FAPESP - processo $n^{\circ}$ 2009/15831-0), cujos dados foram coletados entre 2010 e 2011.

O ISA-2008 constituí-se de uma sub-amostra de indivíduos participantes do estudo intitulado "Inquérito de Saúde de Base Populacional no Município de São Paulo" (ISA-Capital), inquérito domiciliar de saúde, de base populacional, financiado pela Secretaria Municipal de Saúde de São Paulo e conduzido em 2008 e 2009.

\subsubsection{ETAPA 3 - AVALIAÇÃO E COMPARAÇÃO DA REFEIÇÃO}


Para avaliar e comparar a principal refeição consumida no Brasil e Reino Unido utilizou-se os dados do Inquérito Nacional de Alimentação (INA/POF 2008/09) e do National Diet and Nutrition Survey (NDNS).

Resultados da aplicação do MMQI em ambos os países, bem como a comparação dos achados em cada um deles, estão descritos no manuscrito 3 da seção "Resultados e Discussão". Além disto, estão descritas no manuscrito 4 da seção "Resultados e Discussão" as características, e fatores associados, da principal refeição consumida nas cinco macrorregiões brasileiras (norte, nordeste, centrooeste, sudeste e sul).

\subsection{DELINEAMENTO DO ESTUDO}

Estudo transversal, de base populacional, por meio de inquérito domiciliar.

\subsection{CASUÍSTICA}

\subsection{1. ÍNQUERITO DE SAÚDE DE SÃO PAULO - ISA-CAPITAL 2008}

No ISA-Capital, foram definidos oito domínios de estudo formados pelos grupos sexo/idade, sendo, para cada grupo, planejado a realização de 420 entrevistas, perfazendo um tamanho amostral total de 3360 indivíduos. Esses domínios amostrais foram: menores de um ano, de 1 a 11 anos de idade, 12 a 19 anos masculino; 12 a 19 anos feminino; 20 a 59 anos masculino; 20 a 59 anos feminino; 60 anos e mais masculino e 60 anos e mais feminino (Cesar et al., 2005). 
Foram sorteados 60 setores censitários dentre os 220 pertencentes à amostra da Pesquisa Nacional por Amostra de Domicílios - PNAD, realizada em 2003 pelo IBGE, e que haviam sido sorteados com probabilidade proporcional ao tamanho. Os domicílios foram sorteados a partir das listagens elaboradas pelo IBGE durante o trabalho de campo da PNAD.

Em cada setor, planejou-se a obtenção de 7 entrevistas de cada grupo sexo/idade de interesse e para se precaver da perda de $20 \%$ de unidades da amostra em função da não resposta, foi previsto o sorteio de 8,75 pessoas em cada grupo sexo/idade $(7 / 0,8=8,75)$.

Para este estudo, foram utilizados dados de 956 indivíduos de ambos os sexos (332 adolescentes, 350 adultos e 274 idosos) entrevistados no ISA-Capital e no ISA2008, que apresentavam os dados de consumo alimentar e haviam consumido o almoço no dia anterior a coleta de dados. O tamanho mínimo de 300 possibilita estimar uma prevalência de 0,5 com erro de 0,07 , níveis de confiança de $95 \%$ e um efeito de delineamento de 1,5 .

\subsubsection{INQUÉRITO NACIONAL DE ALIMENTAÇÃO - INA/POF 2008/09}

O Inquérito Nacional de Alimentação (INA) compreende o bloco de consumo alimentar individual da Pesquisa de Orçamentos Familiares (POF). A POF visa, principalmente, mensurar as estruturas de consumo, gastos, rendimento e parte da variação patrimonial das famílias, incluindo dados de consumo alimentar individual (INA), que foram coletados em uma sub-amostra da própria POF, entre os anos de 2008 e 2009, com duração de 12 meses. 
A amostragem da POF 2008/09, representativa do Brasil, foi realizada por conglomerados em dois estágios, sendo os setores censitários as unidades primárias de amostragem, selecionados por meio de amostragem aleatória simples, e os domicílios particulares permanentes as unidades secundárias de amostragem, selecionados mediante sorteio aleatório simples sem reposição, dentro de cada setor censitário.

O tamanho da amostra completa da POF 2008/09 foi de 4.696 setores censitários, com 59.548 domicílios sorteados, no entanto apenas 13.569 domicílios foram sorteados para ser entrevistado sobre consumo alimentar. Neste trabalho foram utilizados apenas os dados de consumo alimentar individual referente aos adultos (19-59 anos), totalizando 22742 indivíduos, de um universo de 34003 entrevistados (adolescentes, adultos e idosos).

Detalhes da metodologia da POF 2008/09 foram descritos e publicados pelo Instituto Brasileiro de Geografia e Estatística (IBGE, 2011).

\subsubsection{NATIONAL DIET AND NUTRITION SURVEY - NDNS}

O National Diet and Nutrition Survey (NDNS), realizado entre os anos de 2009 e 2012, tem como um dos principais objetivos disponibilizar informações sobre o consumo alimentar e estado nutricional da população residente no Reino Unido (Figura 1). 


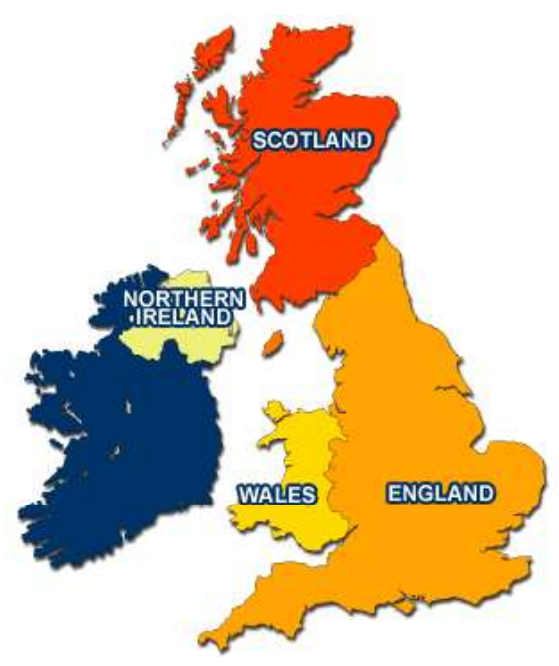

Figura 1. Países que compreendem o Reino Unido.

O estudo coletou dados representativos do Reino Unido, com amostra de 1000 pessoas por ano, 500 adultos (com 19 anos ou mais) e 500 crianças (com idades entre 1,5-18 anos), sendo o primeiro ano de coleta em 2009, segundo em 2010 e terceiro em 2011 e quarto em 2012.

A amostragem foi realizada por conglomerados em dois estágios, sendo o primeiro formado pelos setores censitários (unidades primárias de amostragem) determinados com base no arquivo de códigos postais de todos os endereços do Reino Unido, e o segundo pelos domicílios (unidades secundárias de amostragem), que foram selecionados por sorteio aleatório em cada setor.

Considerando os quatro anos de coleta, a amostra final foi composta 9.990 domicílios, distribuídos em 370 setores censitários. Para este trabalho foram utilizados apenas os dados referentes aos adultos (19 anos ou mais), totalizando 2000 indivíduos.

Detalhes da metodologia do NDNS foram descritos e publicados pelo Departamento de Saúde do Reino Unido (DH, 2013). 


\subsubsection{COLETA DOS DADOS}

Em ambos os estudos os indivíduos foram questionados no domicilio por entrevistadores treinados. Foi aplicado o questionário sobre condições sóciodemográficas e inquérito alimentar.

\subsubsection{INQUÉRITO ALIMENTAR}

No ISA-CAPITAL o consumo alimentar foi medido por meio da aplicação do R24h, utilizando o método AMPM (Automated Multiple-Pass Method). Neste método, o respondente é guiado por meio de cinco passos (listagem rápida; revisão da listagem rápida; nomeação das refeições; ciclo de detalhamento e revisão geral), em um processo padronizado, que visa manter o indivíduo interessado e engajado na entrevista, ajudando-o a se recordar de todos os itens consumidos. Para padronização na coleta de dados foi realizado treinamento dos entrevistadores, com utilização de formulário padrão para aplicação do R24h e manual explicativo para o seu preenchimento. As coletas foram realizadas aleatoriamente entre os dias da semana e meses do ano. Anteriormente à digitação dos dados de consumo alimentar, as informações contidas em cada R24h foram checadas a fim de monitorar a qualidade das entrevistas e definir a padronização para quantidades e receitas. Os recordatórios alimentares foram convertidos em valores de nutrientes utilizando o software Nutrition Data System for Research (NDSR, versão 2007, Nutrition Coordinating Center [NCC], University of Minnesota, Minneapolis), que tem como principal base de dados a tabela de composição de alimentos americana (USDA). 
Nos estudos INA/POF 2008/09 e NDNS o consumo alimentar foi medido por meio do autopreenchimento de registros alimentares, sendo duas medidas em dias não consecutivos para entrevistados pelo INA/POF 2008/09 e quatro medidas (dois dias de semana e dois de final de semana) para entrevistados pelo NDNS. Orientouse a anotação sob a forma de medidas caseiras, o preenchimento dos horários e locais das refeições (dentro ou fora do lar), e a descrição detalhada de todos os alimentos e bebidas consumidos; incluindo o modo de preparo, os ingredientes e as marcas comerciais. O controle de qualidade na coleta dos dados dietéticos foi realizado pelos entrevistadores treinados, que revisaram as informações contidas nos registros alimentares a fim de detectar falhas no preenchimento e proceder às correções necessárias. Itens comumente omitidos como balas e doces em geral, além de bebidas como cafés e refrigerantes, tiveram seu consumo investigado pelo entrevistador.

\subsection{ANÁLISE DOS DADOS}

Foram utilizadas duas diferentes abordagens para a identificação e avaliação da qualidade da refeição: (1) abordagem híbrida, com a diferenciação da composição das refeições por meio de técnicas de redução de dados, e (2) abordagem dirigida pela hipótese, através da aplicação do MMQI (Ocke, 2013).

\subsubsection{ABORDAGEM HÍBRIDA}

A descrição e caracterização da principal refeição ocorreram pela aplicação da árvore de decisão, técnica de redução de dados (Data Mining). A árvore de decisão foi utilizada a fim de descrever as diferenças existentes na composição da 
principal refeição consumida em ambos os países, mostrando o quanto cada grupo de alimentos é característico de cada país, e o diferencia do outro.

O Data Mining, principal etapa do processo de descoberta de conhecimentos em bases de dados (Knowledge Discovery in Databases), refere-se à aplicação de algoritmos para extrair modelos dos dados, permitindo a identificação de padrões previamente desconhecidos (Lamboia e Pereira, 2005). A escolha das técnicas de Data Mining depende fundamentalmente do objetivo do processo de descoberta de conhecimento, que pode ser o de classificação, agrupamento ou regressão (Berry e Linoff, 2000). Dentre as principais técnicas de classificação encontra-se a árvore de decisão, técnica de análise supervisionada de dados utilizada neste trabalho, a semelhança de Hearty e Gibney (2008).

Figura 2. Exemplo de Árvore de Decisão

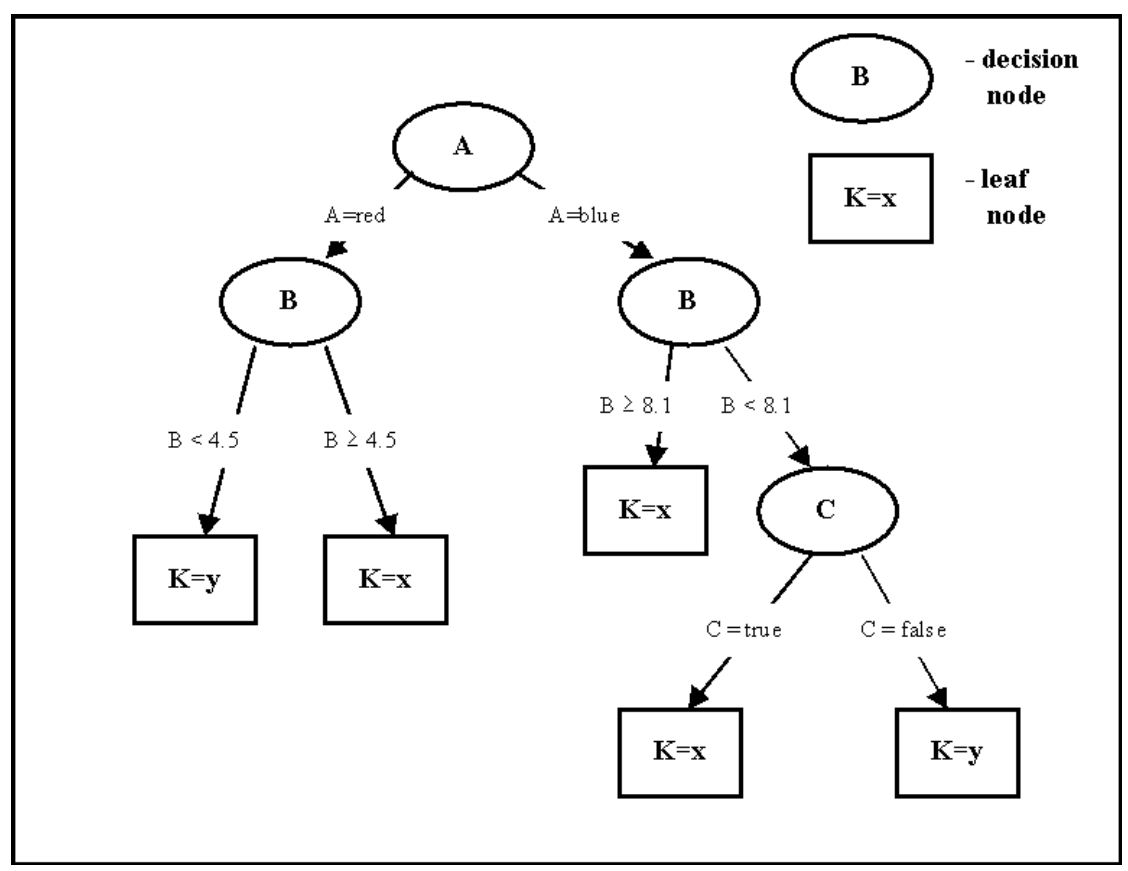


A árvore de decisão, exemplificada na figura 2, utiliza-se de a estratégia “dividir-e-conquistar", onde um problema complexo é decomposto em subproblemas mais simples, e pode ser utilizada tanto como modelagem preditiva, como descritiva (Tan, 2005). Na modelagem descritiva, o modelo de classificação é utilizado como ferramenta que distingui diferentes classes.

A construção da árvore de decisão para a descrição e a caracterização da principal refeição requereu que os alimentos relatados nos registros alimentares fossem agrupados, originando os atributos, de valores discretos (consumo e não consumo) que formaram à árvore. Uma forma de selecionar atributos é usando o conhecimento do especialista sobre quais informações podem ser úteis para um determinado contexto. Manter atributos irrelevantes pode confundir o algoritmo empregado e levar a descoberta de padrões de baixa qualidade.

O agrupamento permitiu a redução do número de itens, juntando alimentos que, apesar de semelhantes do ponto de vista nutricional e uso culinário, apresentavam consumo distinto entre os países, como, por exemplo, a mandioca e a batata, que formam o grupo dos tubérculos. Dessa forma, anteriormente à aplicação do algoritmo, os alimentos foram agrupados em 25 grupos de acordo com suas características nutricionais, culinárias e hábito alimentar das populações; a saber: arroz; outros cereais; leguminosas; frutas; verduras e legumes crus; verduras e legumes cozidos; tubérculos fritos; tubérculos não fritos; sopas; massas; sanduiches; snacks; pizza; pães; sobremesa; carne não processada; peixe e frutos mar; carne processada; ovos; leite e derivados; queijos; bebidas alcoólicas; bebidas adoçadas; café; chá. Ademais, para posterior validação da árvore, o banco de dados (já 
agrupado) foi dividido em dois novos bancos de dados, um banco treinamento (com dois terços da amostra) e um banco validação (com um terço da amostra).

A árvore de decisão foi gerada seguindo-se a construção Top-down de particionamento recursivo (CART-algoritmo, rpart-rotina), visando alta taxa de predição, com escolha correta dos atributos que representaram os "nós", de modo que a árvore final fosse a menor possível (Terry et al, 2015). O atributo mais importante foi apresentado como o primeiro "nó", e os atributos menos importantes foram mostrados nos "nós" subsequentes. Os critérios utilizados na ordenação dos atributos que estruturaram a árvore são: (1) Índice de Gini, indicando a homogeneidade e pureza do atributo; e (2) ganho de informação, indicando o quanto um dado atributo foi capaz de separar os ramos e as folhas da árvore (Gama, 2002). Quanto menor o valor do Índice de Gini, mais heterogênia é a classificação, maior é o ganho de informação, melhor é a divisão feita pelo atributo e maior é a sua importância para entrada na árvore.

Para evitar o ajuste demasiado, overfitting, a árvore de decisão, após sua construção, foi podada (Freitas, 2000). A realização da poda, simplificação da árvore, baseou-se na acurácia e nos valores dos erros atribuídos a cada ramo da árvore. Foram podados os ramos que produziram o menor aumento na taxa de erro por folha podada e os nós que, ao serem retirados, não reduziram a acurácia (Kohavi e Quinlan, 2002).

\subsubsection{ANÁLISE ESTATÍSTICA}


Os dados foram tratados estatisticamente utilizando-se o software Stata (versão 13), e os resultados foram obtidos com as correções necessárias conforme desenho amostral através de análises realizadas no módulo "Survey". Para a construção da árvore de decisão utilizou-se o ambiente - R (versão 3.2.3).

\subsection{ASPECTOS ÉTICOS}

O projeto de pesquisa utilizou dados secundários dos projetos mencionados acima, atendendo às exigências da resolução $\mathrm{n}^{\circ} 196$ de 10 de outubro de 1996 do Conselho Nacional de Saúde que regulamenta pesquisas envolvendo seres humanos.

O projeto foi aprovado pelo Comitê de Ética em Pesquisa da Faculdade de Saúde Pública da Universidade de São Paulo (Anexo IV).

\section{RESULTADO DE DISCUSSÃO}

Esta seção divide-se em três etapas: 1) revisão sistemática da literatura; 2) desenvolvimento do indicador; e 3) avaliação e comparação da refeição.

\subsection{REVISÃO SISTEMÁTICA}

\subsubsection{MANUSCRITO 1}

Indices for assessment of nutritional quality of meals: a systematic review

B. M. Gorgulho, G. K. Pot, F. M. Sarti, D. M. Marchioni

Artigo científico publicado no British Journal of Nutrition, 115(11) p. 2017-2024.

\section{Abstract}


This systematic review aimed to synthesize information on indices developed to evaluate nutritional quality of meals. A strategy for systematic search of literature was developed using keywords related to assessment of meal quality. Databases searched included Science Direct, Pubmed, Lilacs, Scielo, Scopus, Cochrane, Embase and Google Scholar. The literature search resulted in seven different meal quality indices. Each article was analyzed in order to identify the following items: authors; country; year; study design; population characteristics; type of meal evaluated; dietary assessment method; characteristics evaluated (nutrients or food items); score range; indice components; nutritional references; correlations performed; validation; and relationship with an outcome (if existing). Two studies developed instruments to assess the quality of breakfast, three analyzed lunch, one evaluated dinner and one was applied to all types of meals and snacks. All meal quality indices reviewed were based on the evaluation of presence or absence of food groups and relative contributions of nutrients, according to foodbased guidelines or nutrient references, adapting the daily dietary recommendations to one specific meal. Most of the indices included three items as components for meal quality assessment: (I) total fat or some specific type of fat; (II) fruits and vegetables; and (III) cereals or whole grains. This systematic review indicates aspects that need further research, particularly to the numerous approaches to assessing meals considering different foods and nutrients, and the need for validation studies of meal indices.

Key words: meal quality, meal index, meal score, nutrition, systematic review.

\section{Introduction}


The influence of the food intake in health is unquestionable ${ }^{(1)}$. However, because of the complexity of diet and the potential for interactions among dietary components, approaches that focus on individual foods or nutrients may miss information on the role of diet in disease etiology. In this way, a more holistic approach has been applied, and, since the 1990s, dietary indices to evaluate the global quality of meals and diets have been proposed ${ }^{(2,3)}$. These instruments are predefined summary measures of overall food intake that may be used as a simple and quick instrument for the assessment of nutritional quality, in order to evaluate adherence to dietary guidelines and to monitor overall changes in food consumption patterns $^{(4)}$. Nonetheless, although the idea of analyzing food intake at meal level is not exactly new ${ }^{(5-8)}$, data on meals nutritional composition are scarce in literature.

Meals are eating events that include certain combination of foods and beverages in a concentrated period, combining taste and food consumption. Definitions of meal have been described from a number of different perspectives, such as, self-report by participants, time of day, and energy content ${ }^{(9,10)}$. Identifying and analyzing meals allow understand how different combinations of foods and beverages at eating events could influence the overall diet quality and health outcomes $^{(11-13)}$.

Nutritional advices considering a meals-based approach might be easier and more practical way to the population understand and follow dietary guidelines ${ }^{(14)}$. In 2014, the Brazilian Ministry of Health published the first food guide with recommendations for meals, highlighting the commensality importance to healthy food habits ${ }^{(15)}$. The new guide recommends also moderation in the use of food 
products sold ready for consumption, and encourages the consumption of fresher foods such as fruits and vegetables ${ }^{(15)}$.

There are some systematic reviews performed to date on healthy eating indexes and other indicators to evaluate global dietary quality ${ }^{(2-4.16-17)}$. However, no systematic review has described and compared instruments developed to summarize meals, measure meals nutritional quality and evaluate the adherence of meals to the nutritional recommendations, up to date. Considering the Cochrane recommendations, PRISMA checklist, and PICOS strategy, the aim of this systematic review was to describe and compare indices (predefined in the literature) for assessment of nutritional quality of meals.

\section{Materials and methods}

Search strategy, selection criteria and data extraction

A search regarding original studies on meal quality index was performed in the published literature, in order to achieve the results presented in this systematic review. Databases searched included: Science Direct, PubMed, Lilacs, Scielo, Scopus, Cochrane, Embase and Google Scholar. A search strategy was developed using keywords related to the assessment of nutritional quality of meals and was initially developed in PubMed and adapted for use in other databases. The following search string was used: (meal* OR lunch OR dinner OR breakfast OR meal quality OR dietary pattern OR dietary quality OR eating index OR restaurant menu OR menu component OR meal score OR meal plate OR food service). The search was limited by language (English and Portuguese) and year of publication (1965 until 
2014). Using an adaptation of the PICOS strategy ${ }^{(18)}$, inclusion and exclusion criteria are described in Table 1.

Table 1. Inclusion and exclusion criteria used for the present review.

\begin{tabular}{|c|c|c|}
\hline $\begin{array}{c}\text { Study } \\
\text { characteristic }\end{array}$ & Inclusion criteria & Exclusion criteria \\
\hline Population & Studies with humans & Studies with no humans \\
\hline Intervention & $\begin{array}{l}\text { Evaluation of meal quality using a } \\
\text { composite index proposed to } \\
\text { synthesize nutritional quality }\end{array}$ & $\begin{array}{l}\text { Description of meal quality according to } \\
\text { content of nutrients }\end{array}$ \\
\hline Outcome & $\begin{array}{l}\text { Methodological instrument to } \\
\text { assessment of overall nutritional } \\
\text { quality of meals }\end{array}$ & $\begin{array}{l}\text { Analysis without results on development, } \\
\text { evaluation or application of composite } \\
\text { index to synthesize nutritional quality }\end{array}$ \\
\hline Sudy type & $\begin{array}{c}\text { Observational studies, cohort studies, } \\
\text { case-control, systematic review, meta- } \\
\text { analysis }\end{array}$ & Animal research \\
\hline
\end{tabular}

Articles that presented results on development, evaluation and application of methodological instruments aimed to assessment of the nutritional quality of meals were considered eligible for inclusion, regardless of the definition used to classify the eating events (self-report, period of consumption, energy content or neutral). Also, there were no restrictions in relation to the dietary assessment methods used or potential outcomes associated to the meal quality. Duplicate articles were identified and eliminated using as key terms: first author, publication year, journal title, volume, and number of the first page. Title and abstract of relevant articles and potentially relevant references were analyzed, and its references and bibliographies were hand searched in order to provide further contributions to the systematic review. The assessment of articles and the data extraction were made by two 
independent reviewers (BG and DMM), applying the inclusion criteria described. Discrepancies in relation to the papers and information to be included in the systematic review were solved by a third reviewer.

A database containing detailed information from each article was developed, in order to allow a comprehensive analysis of the meal quality indexes proposed: authors; country; year; study design; population characteristics; type of meal evaluated; dietary assessment method; characteristics evaluated (nutrients or food items); score range; indices components; nutritional references; correlations performed; validation; and relationship with an outcome (if existing).

A narrative review of the seven studies included was performed, the studies were compared and the key issues to be considered to develop an indicator were discussed, including the components, cut off values and scoring ${ }^{(3)}$. Data about content and construct validity and reliability of the indicators were observed. Guenther et al. suggest that besides the correlation between the scores and nutrients and guidelines, is necessary to verify if the indicator can distinguish groups with known differences in diet quality, detect more than one dimension of intake, and be sensitive to identify meaning full differences ${ }^{(19)}$.

The systematic review protocol was developed according to the Cochrane recommendations $^{(20)}$ and the Preferred Reporting Items for Systematic Reviews and Meta-Analyses (PRISMA) ${ }^{(21)}$. The systematic review protocol was registered at the international prospective register of systematic review, PROSPERO ${ }^{(22)}$ (registration number CRD42014013519). 


\section{Results}

Studies included in the systematic review

The flow diagram of the systematic search is presented in Figure 1. The literature search resulted in 22,963 citations. The initial screening of the references based on title excluded 21,038 references and 548 duplicate articles were identified and removed. Second screening of the references based on the contents of the abstract excluded 730 references. Five new studies were identified after examining the list of references from the selected papers and these were included in the review.

The main reason for exclusion was that most of the studies did not evaluate the nutritional quality of the meals using a composite index as instrument to synthesize the measurement of nutritional quality, such as a score or a checklist.

Finally, eight studies were identified. Among these, two were about the same instrument ${ }^{(23,24)}$, resulting in seven indices included in this systematic review (Table 2). With respect to the country of origin, two studies were carried out in Spain ${ }^{(25,26)}$, two in Denmark ${ }^{(27,28)}$, one in Sweden ${ }^{(29)}$, one in the United States ${ }^{(30)}$ and one in Brazil $^{(23)}$. Among the studies included in the systematic review, neither one investigated the meal quality relationship with health outcomes. 


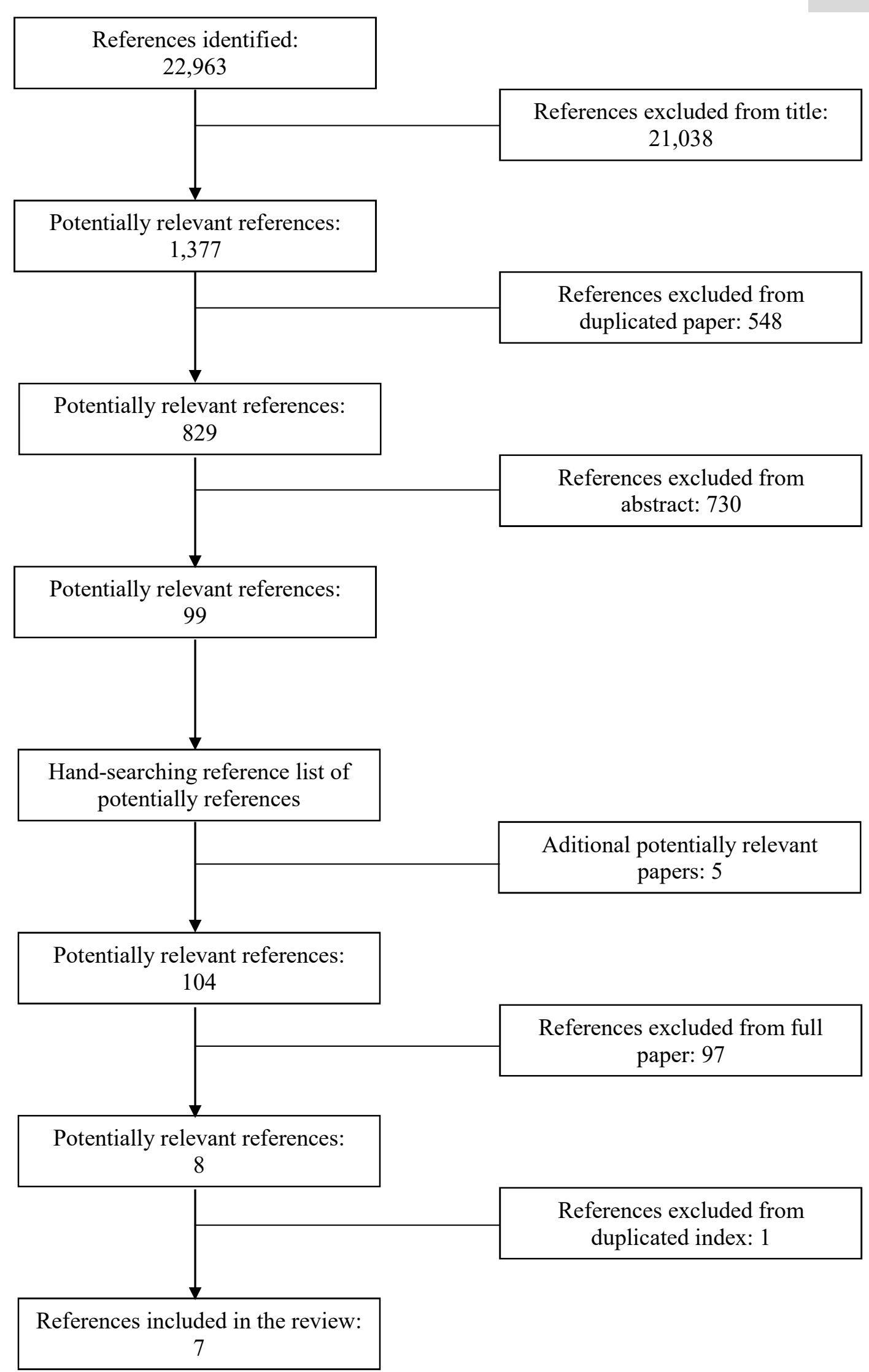

Figure 1. Flow diagram illustrating the screening process of eligible studies. 
In relation to the nutritional intake, three of the selected studies analyzed the meal quality considering a qualitative description ${ }^{(25,29,30)}$, while three studies adopted ${\text { a quantitative } \operatorname{approach}^{(23,27,28)} \text {, and one used both possibilities }}^{(26)}$ (Table 2).

\section{Type of meal evaluated}

Table 2. Findings from studies included in the systematic review.

\begin{tabular}{|c|c|c|c|c|c|}
\hline Reference & Country & $\begin{array}{c}\text { Population } \\
\text { characteristics }\end{array}$ & $\begin{array}{l}\text { Type of meal } \\
\text { evaluated }\end{array}$ & $\begin{array}{c}\text { Dietary } \\
\text { assessment } \\
\text { method } \\
\end{array}$ & Nutritional reference \\
\hline $\begin{array}{l}\text { Wissing U et al } \\
\text { (1998) }\end{array}$ & Sweden & $\begin{array}{c}\text { Women aged } 60 \text { years } \\
\text { or older }\end{array}$ & $\begin{array}{l}\text { Meals and } \\
\text { snacks }\end{array}$ & $\begin{array}{l}\text { Seven days food } \\
\text { diary }\end{array}$ & $\begin{array}{l}\text { Swedish Nutrition } \\
\text { Recommendations }\end{array}$ \\
\hline $\begin{array}{l}\text { Van deb Boom A } \\
\text { et al (2006) }\end{array}$ & Spain & $\begin{array}{l}\text { Children, adolescents } \\
\text { and young adults aged } \\
2 \text { to } 24 \text { years }\end{array}$ & Breakfast & 24-hour recall & $\begin{array}{l}\text { Energy and Nutrients } \\
\text { Recommendations for the } \\
\text { Spanish Population }\end{array}$ \\
\hline $\begin{array}{l}\text { Bandoni DH and } \\
\text { Jaime PC (2008) }\end{array}$ & Brazil & $\begin{array}{c}\text { Workers } \\
\text { Not described }\end{array}$ & $\begin{array}{l}\text { Lunch, supper } \\
\text { and late } \\
\text { supper }\end{array}$ & Menu & Brazilian Dietary Guindeline \\
\hline $\begin{array}{l}\text { Lassen AD et al } \\
\text { (2010) }\end{array}$ & Denmark & $\begin{array}{c}\text { Workers } \\
\text { Not described }\end{array}$ & Lunch & $\begin{array}{l}\text { Double weighed } \\
\text { portions }\end{array}$ & $\begin{array}{l}\text { Danish Food and Nutrient } \\
\text { recommendations and USA } \\
\text { Food Guide Pyramid }\end{array}$ \\
\hline $\begin{array}{c}\text { Fulkerson JA et } \\
\text { al (2012) }\end{array}$ & USA & $\begin{array}{l}\text { Adults } \\
\text { 23-53 years }\end{array}$ & Evening meal & Meal screener & USA Food Guide Pyramid \\
\hline $\begin{array}{l}\text { Monteagudo C et } \\
\text { al (2012) }\end{array}$ & Spain & $\begin{array}{l}\text { Students aged } 8-17 \\
\text { years }\end{array}$ & Breakfast & $\begin{array}{l}\text { Validated semi- } \\
\text { quantitative food } \\
\text { frequency } \\
\text { questionnaire } \\
\text { dived in five } \\
\text { meals }\end{array}$ & $\begin{array}{l}\text { Mediterranean Dietary } \\
\text { Recomendations }\end{array}$ \\
\hline $\begin{array}{l}\text { Sabinsky MS et } \\
\text { al (2012) }\end{array}$ & Denmark & $\begin{array}{c}\text { Sudents aged } 7-13 \\
\text { years }\end{array}$ & Lunch & $\begin{array}{l}\text { One weighed food } \\
\text { record }\end{array}$ & Danish Dietary Guidelines \\
\hline
\end{tabular}

Most researchers have defined meals and snacks separately, classifying the eating event based on participant/institution report ${ }^{(23,27,28)}$, and period of day ${ }^{(26,30)}$. Just one used a neutral definition, considering both, meals and snacks ${ }^{(29)}$. Two 
studies developed an instrument to the assessment of breakfast quality ${ }^{(25,26)}$, three analyzed lunch ${ }^{(23,27,28)}$, one evaluated dinner ${ }^{(30)}$, and one was applied to all types of meals and snacks ${ }^{(29)}$. The type of meal evaluated in each study is presented in Table 2.

The Breakfast Quality Index ${ }^{(26)}$ and the Breakfast Score ${ }^{(25)}$ were specifically developed to evaluate the nutritional quality of breakfasts consumed by children and adolescents, and should not be used to evaluate other types of meals. The components of these indices were based on foods typically consumed at breakfast, excluding other food groups.

The Meal Index of Dietary Quality ${ }^{(28)}$, the Meal Quality Index ${ }^{(23)}$, and the Healthy Meal Quality ${ }^{(27)}$ were developed to evaluate the quality of lunch; and the index Five Food Group and Healthfulness Score ${ }^{(30)}$ was developed to evaluate the quality of dinner. However, considering the components proposed, the four indices could be applied on lunch and dinner. In fact, the difference is that the Meal Index of Dietary Quality was proposed for meals consumed by adolescents at the school, the Meal Quality Index and the Healthy Meal Quality for meals consumed by adults at work and the Five Food Group and Healthfulness Score for meals served at home by adults residing with child.

The Meal Classifications System was used to evaluate all types of meals and snacks consumed by elderly women, reflecting eating frequency and key nutrients ${ }^{(29)}$.

\section{Dietary assessment method}


The dietary assessment method used in each study is presented in Table 2 . The studies that were analyzed in the systematic review were based on the collection of dietary information through application of 24 -hour recall ${ }^{(25)}$, food diary ${ }^{(29)}$, food frequency questionnaire ${ }^{(26)}$, menu $^{(23)}$, weighted foods ${ }^{(27,28)}$ and meal screener ${ }^{(30)}$. The methods observed for data collection regarding dietary intake are the ones traditionally used for research in nutrition, with exception of the meal screener, which was proposed and validated especially for development of the meal quality index in the study conducted by Fulkerson et al, 2012(30). The meal screener is an open-ended questionnaire for participants to describe foods that were served and consumed, including specific questions about the type of food and the method of preparation $^{(30)}$.

\section{Nutritional references}

The nutritional references employed to develop the indices included in this review were: the Food Guide Pyramid developed by the U.S. Department of Agriculture (USDA) ${ }^{(31)}$, the Danish Dietary Guidelines ${ }^{(32)}$, the Mediterranean Diet Guidelines $^{(33)}$, the Brazilian Dietary Guidelines $^{(34)}$, the Swedish Nutrition Recommendations $^{(35)}$ and the Energy and Nutrients Recommendations for the Spanish Population ${ }^{(36)}$. The Food Guide Pyramid and the Danish, Mediterranean and Brazilian guidelines were based on food items, meaning that usually are based on suggestions regarding intake of food portions and portion sizes, while the Swedish and Spanish nutritional recommendations are based on quantitative intake, in grams or percentage contribution of energy and nutrients ${ }^{(37)}$. 
The nutritional references suggest dietary recommendations for daily food intake, considering the combination of meals and snacks consumed during one day. Therefore, these indices were based on the evaluation of presence or absence of food groups and relative contributions of nutrients recommended, adapting the recommendations for a dietary day to one specific meal.

\section{Components}

The components of each indicator included the systematic review is presented in Table 3. The number of components among the indices range between 3 and 15 items. Most of the indices included three items as components for meal quality assessment: (I) total fat or some specific type of fat ${ }^{(23,26-29)}$; (II) fruits and vegetables $^{(23,26-29)}$; and (III) cereals or whole grains ${ }^{(25-28)}$. Other items usually prevalent in meal quality indexes were: dairy products and calcium ${ }^{(25,26)}$; diversity of food items and food groups ${ }^{(23,30)}$; and added $\operatorname{sugar}^{(28,29)}$.

The Five Food Group and Healthfulness Score, the Breakfast Score and the Qualitative Meal Classifications System were based on the evaluation of the meal quality using food items and food groups as components ${ }^{(25,29,30)}$. The Meal Quality Index, the Healthy Meal Quality, the Breakfast Quality Index and the Meal Index of Dietary Quality were based on the assessment of the meal quality using food items, food groups and nutrients as components ${ }^{(23,26-28)}$. None of the studies proposed the evaluation of the nutritional quality of meals based on indices that included only nutrients (Table 3). 
Table 3. Indices included in the systematic review.

\begin{tabular}{|c|c|c|c|c|c|c|c|}
\hline \multirow{2}{*}{ Reference } & \multirow{2}{*}{ Index } & \multirow{2}{*}{$\begin{array}{l}\text { Characteristics } \\
\text { evaluated in } \\
\text { the meal }\end{array}$} & \multirow{2}{*}{ Index components } & \multirow{2}{*}{ Score range } & \multicolumn{2}{|c|}{ Reported assossiation } & \multirow{2}{*}{ Validation } \\
\hline & & & & & Energy & Nutrients & \\
\hline $\begin{array}{l}\text { Wissing U } \\
\text { et al (1998) }\end{array}$ & $\begin{array}{l}\text { The } \\
\text { Qualitative } \\
\text { Meal } \\
\text { Classification } \\
\text { System }\end{array}$ & Food & $\begin{array}{l}\text { Meat, fish, shellfish, poultry, } \\
\text { egg, milk; peas, beans, rice, } \\
\text { cereals; potatoes, root } \\
\text { vegetables; vegetables, fruit, } \\
\text { berries; nuts, olives, } \\
\text { avocado; cream, butter, } \\
\text { margarine, oils; alcohol, } \\
\text { pastry, sweets; and coffee, } \\
\text { tea, light drinks }\end{array}$ & $\begin{array}{l}\text { Type of meal } \\
\text { or type of } \\
\text { snack }\end{array}$ & NA & NA & $\begin{array}{l}\text { Ability to } \\
\text { assess } \\
\text { dietary } \\
\text { quality }\end{array}$ \\
\hline $\begin{array}{c}\text { Van deb } \\
\text { Boom A et } \\
\text { al (2006) }\end{array}$ & $\begin{array}{l}\text { Breakfast } \\
\text { score }\end{array}$ & Food & $\begin{array}{l}\text { Dairy product, cereal } \\
\text { product and fruit }\end{array}$ & $0-3$ points & NA & NA & NA \\
\hline $\begin{array}{l}\text { Bandoni } \\
\text { DH and } \\
\text { Jaime PC } \\
(2008)\end{array}$ & $\begin{array}{l}\text { Meal Quality } \\
\text { Index }\end{array}$ & $\begin{array}{l}\text { Food and } \\
\text { nutrients }\end{array}$ & $\begin{array}{l}\text { Fruits and vegetable, } \\
\text { carbohydrates, total fat, SFA } \\
\text { and meal variability }\end{array}$ & $0-100$ points & Yes & Yes & $\begin{array}{l}\text { Internal } \\
\text { consistency }\end{array}$ \\
\hline $\begin{array}{l}\text { Lassen AD } \\
\text { et al }(2010)\end{array}$ & $\begin{array}{l}\text { Healthy Meal } \\
\text { Quality }\end{array}$ & $\begin{array}{l}\text { Food and } \\
\text { nutrients }\end{array}$ & $\begin{array}{c}\text { Fruits and vegetables, total } \\
\text { fat, fat quality and } \\
\text { wholegrain }\end{array}$ & $0-3$ points & Yes & Yes & $\begin{array}{l}\text { Ability to } \\
\text { assess } \\
\text { dietary } \\
\text { quality }\end{array}$ \\
\hline $\begin{array}{l}\text { Fulkerson } \\
\text { JA et al } \\
\text { (2012) }\end{array}$ & $\begin{array}{l}\text { The Five } \\
\text { food group } \\
\text { Score and } \\
\text { The } \\
\text { Healthfulness } \\
\text { score }\end{array}$ & Food & $\begin{array}{c}\text { Food group, food, } \\
\text { preparation method and } \\
\text { high-calorie sauce added }\end{array}$ & $\begin{array}{l}0-5 \text { points and } \\
0-10 \text { points }\end{array}$ & NA & NA & NA \\
\hline $\begin{array}{l}\text { Monteagudo } \\
\text { C et al } \\
(2012)\end{array}$ & $\begin{array}{l}\text { Breakfast } \\
\text { Quality } \\
\text { Index }\end{array}$ & $\begin{array}{l}\text { Food and } \\
\text { nutrients }\end{array}$ & $\begin{array}{l}\text { Cereals, fruit and vegetables, } \\
\text { dairy products, MUFA, } \\
\text { simple sugars, energy intake, } \\
\text { calcium, MUFA:SFA ratio, } \\
\text { SFA and trans fats }\end{array}$ & $0-10$ points & NA & NA & NA \\
\hline $\begin{array}{l}\text { Sabinsky } \\
\text { MS et al } \\
(2012)\end{array}$ & $\begin{array}{l}\text { Meal Index } \\
\text { of Dietary } \\
\text { Quality } \\
\text { (Meal IQ) } \\
\end{array}$ & $\begin{array}{l}\text { Food and } \\
\text { nutrients }\end{array}$ & $\begin{array}{l}\text { Fat, saturated fat, sweet } \\
\text { snacks, whole grain, fish, } \\
\text { fruits and vegetables }\end{array}$ & $0-28$ points & No & Yes & $\begin{array}{l}\text { Ability to } \\
\text { assess } \\
\text { dietary } \\
\text { quality }\end{array}$ \\
\hline
\end{tabular}

NA: not applicable

The Five Food Group and Healthfulness Score was based on the composition of two scale scores: the Five Food Group Score, in order to assess the presence of food items from the five major groups of the Food Guide Pyramid developed by the U.S. Department of Agriculture (USDA); and the Healthfulness Scale Score, in order to assess the healthfulness of foods based on preparation methods and added fats. The Five Food Group Score assigns one point for the inclusion of at least one food 
item from each food group (range $=0$ to 5 ) and the Healthfulness Scale Score assigns one point for the inclusion of food items from each major groups plus one point for the adoption of healthy preparation method, and subtracts one point for the inclusion of sauces with high caloric content (range $=0$ to 10$)^{(30)}$.

The Breakfast Score considered the consumption of three groups (dairy products, cereals and fruits), scoring one point for each group consumed during breakfast. Thus, a complete breakfast that included a dairy product, a cereal and a fruit should obtain a maximum of three points ${ }^{(25)}$.

The Qualitative Meal Classification System was based on eight food categories (representing one key nutrient each) combined into four types of meal (complete, incomplete, less balanced and vegetarian meals) and three types of snacks (high-, mixed- and low quality snacks) ${ }^{(29)}$.

The Meal Quality Index was composed by five components, namely: content of fruits and vegetables, content of carbohydrates, content of total fat, content of saturated fat and menu variety; scoring each component from zero to 20 points $(\text { range }=0 \text { to } 100)^{(23)}$.

The Healthy Meal Quality and the Meal Index of Dietary Quality came from the same research group and, although very similar, were developed for different populations $^{(27,28)}$. The Healthy Meal Index was developed to reflect the nutritional profile of canteen meals ${ }^{(27)}$, while the Meal Index of Dietary Quality was developed to assess the dietary quality of school lunches ${ }^{(28)}$. Three components were prioritized in the Healthy Meal Index: fruits and vegetables, total fat and fat quality, and whole 
grains and potatoes. Each component could be scored from zero to one point and were added up to determine the overall score (range $=0$ to 3$)^{(27)}$. The Meal Index of Dietary Quality considered seven components, including nutrients and food groups: fat, saturated fats, sweet snacks, whole grain, fish, fruits and vegetables; scoring from zero to 4 each component (range $=0$ to 28$)^{(28)}$.

The Breakfast Quality Index, similarly to the Breakfast Score, took into account the consumption of dairy products, cereals and fruits, also considering the content of selected nutrients. The Breakfast Quality Index scores one point for the consumption of each of the following food items and nutrients: dairy products, cereals, fruit/vegetables, monounsaturated fat acids, sugar (up to $5 \%$ of total daily energy consumption), energy intake (between $20 \%$ and $25 \%$ of total daily energy intake), calcium (between $200 \mathrm{mg}$ and $300 \mathrm{mg}$ ), monounsatured/satured fat acid ratio above the population median, combination of items from cereals, dairy products and fruit/vegetables groups in one meal, and non-consumption of foods with high content of saturated or trans fat acids (range $=1$ to 10$)^{(26)}$.

\section{Cut off of the indices and their components}

The cut off of each indice and its components are presented in Table 3. Six of the studies included in the systematic review proposed the calculation of a score for the nutritional index ${ }^{(23,25-28,30)}$. Indices based on qualitative assessment approach included components on the consumption of specific food groups, attributing a score of zero if the food group was not consumed and one if the food group was consumed $^{(25,26,30)}$. The Meal Index of Dietary Quality and the Meal Quality Index 
proposed cut off values for each component, attributing a score of zero if consumption is lower/higher than this value for items considered healthy/unhealthy (respectively), a score one if consumption is higher/lower than the cut off for items considered healthy/unhealthy (respectively), and intermediate values of consumption receiving proportional scores ${ }^{(23,28)}$.

None of the studies proposed weighting of the items included in the calculation of the index, presenting the components with the same relative importance in the score ${ }^{(23,25-28,30)}$. The Healthy Meal Quality ${ }^{(27)}$ and the Breakfast Score ${ }^{(25)}$ presented the lower score ranges (three points), and the Meal Quality Index (100 points) presented the highest score range ${ }^{(23)}$.

Validation and correlations with energy and nutrientes

The validity and correlations with nutrients verified by each indicator included in the systematic review are presented in Table 3. Certainly, the main risk of bias for these indicators is the insufficient (or absence) of validity and reliability analysis described in the published studies.

Four studies showed some validity analysis of the meal quality indices presented $^{(23,27-29)}$. Among these, three studies evaluated the ability of the index to assess dietary quality using the one-way ANOVA followed by Tukey's post hoc test, if normally distributed, or the Kruskal-Wallis test followed by the Mann-Whitney post hoc test, assessing differences between the categories ${ }^{(27-29)}$. However, the internal consistency of the components was evaluated just in one study; wich applied the Cronbach's Alpha ${ }^{(23)}$. Furthermore, using Pearson and Spearman correlation 
coefficients, the studies that proposed quantitative assessments had analysed the linear relationships between the scores of each component of the indices in relation to the contents of energy and nutrients in the meals ${ }^{(23,27,28)}$.

For the Healthy Meal Index no significant differences were found with respect to the tested background variables (i.e. age, gender and body mass index) over the categories of classification. Energy density, total fat, saturated fat, carbohydrate, and fruits and vegetables were highly significant associated, with higher scores being closer to dietary guidelines ${ }^{(27)}$. The ANOVA showed significant differences between the Meal Index of Dietary Quality scores. A higher score was associated with lower intakes of total and saturated fat, and sugar, and with higher intakes of fiber, fish, fruits and vegetables ${ }^{(28)}$. The Meal Quality Index had a Cronbach's Alpha value higher than $0.60^{(23)}$, as is recommended; and the Qualitative Meal Classification Method found significant differences between the meals classifications, completed meals contained more beta-carotene and ascorbic acid ${ }^{(29)}$.

\section{Discussion}

Although there is widespread recognition of the importance of nutrition and diet for the prevention of chronic diseases, there are only few studies investigating the dietary characteristics of meals. This is the first systematic review on indices proposed to evaluate the nutritional quality of meals. Overall, we found seven indices developed to evaluate the quality of breakfast, lunch and dinner.

None of the articles presented an analysis of the relationship between meal quality and health outcomes, however the indices were developed based on 
nutritional recommendations designed to prevent overweight ${ }^{(36)}$ and, consequently, to target the increasing prevalence of chronic diseases. The evaluation of the nutritional quality of a single meal will not necessarily reflect the daily dietary quality, restricting the direct association between indices and health outcomes. The association of the meal quality with overall dietary intake could be valuable to observe the associations between each meal and dietary quality.

Despite cultural differences, the recommendations for a healthy diet for most countries $^{(36)}$ and for international agencies ${ }^{(37)}$ consistently are high consumption of whole grains, fruits and vegetables, associated with the reduction of total and saturated fats and added sugar. The main purpose of the indices found in the systematic review was to evaluate the adherence of individuals to nutritional recommendations, proposing specific indicators for each country and each population group under assessment. Although indices designed for the assessment of each meal seemed to be developed with this view, the results cannot be easily compared across the studies, considering their different components, score ranges, and population targeted, such as students and workers. Moreover, there is no consensus in the literature regarding the definition of eating occasions ${ }^{(10)}$. Some authors define meals considering the consumption time slot or nutrient content, while other authors define it based on the respondent report ${ }^{(10)}$. This difference in the definitions makes more difficult the comparison of findings, recent study showed that, depending of the meal definition used, meal frequency can be, or not, associated with nutritional status ${ }^{(38)}$. 
Composing a nutritional index is complex and involves many choices related to components, including cut off values to compare with reported intake, and scoring methods ${ }^{(14,19)}$. The assessment of nutritional quality of meals considering nutrients and food groups is usually a strategy used to facilitate the comparison of the dietary quality among different populations. Although there are new proposals on dietary guidelines based on nutritional recommendations for meals ${ }^{(12)}$, there is still lack of quantitative dietary recommendations regarding the meal quality.

The seven meal quality indices identified in this review were based on the assumption that all components have the same impact on health. However, it is possible that some components may present higher weight than others in determining populations' and individuals' health outcomes. Two indices cited were based on the evaluation of presence or absence of certain food items or food groups, and did not consider the amount of each food served and/or consumed ${ }^{(25,30)}$. Nevertheless, it is preferable that the score range represents a proportional measure in relation to caloric intake, instead of proposing simple cut off values, since larger score ranges allow a better distribution of the population studied, identifying possible intake differences between individuals.

The process for development of a nutritional indicator includes its validation, in order to evaluate whether the indicator captures the targeted aspects of the nutritional references, its construct validity and reliability ${ }^{(19)}$. A suitable nutritional indicator may be able to distinguish between consumption groups with significant differences in nutritional quality and to recognise the influence of each component on the overall score of the index ${ }^{(13)}$. Although internal validity analysis is considered 
essential to test the indices ability to properly measure the dimensions under evaluation $^{(39)}$, not all studies presented the test for the proposed indices and its components.

A statistical strategy commonly used to verify the properties of the composite indices proposed for assessment of nutritional quality of meals was the correlation analysis between the score of meal quality index and the amount of macro- and/or micro- nutrients reported in dietary questionnaires ${ }^{(25,26)}$. In addition, it is important to remember that the final score of the indices should be adjusted for energy intake, in order to avoid confounding factors ${ }^{(19,40)}$.

\section{Limitations}

One of the limitations of this study was the inclusion of articles published mainly in English. Since the indices were specific for the country's dietary recommendations, it is possible that there are other publications on the assessment of the nutritional quality of meals in other languages.

Despite all concerns during the literature review and the extensive search in different databases with different combinations of search terms, it is possible that some manuscripts that comprise the inclusion criteria have not been found or not published until the conclusion of this systematic review. Furthermore, this review was limited to composite index and does not include other methods to assess the quality of meals.

\section{Conclusion}


The development and application of meal quality indices is a relatively new matter, begining to be used more often since the last decade. It is noteworthy that the meal quality indices found during the systematic review still need to be internally validated, since it is important to know whether the index reflects the most important nutritional aspects of the dietary intake reported and, in fact, if it assesses the adherence to nutritional recommendations. Moreover, it is important to propose nutritional indices tailored to specific purposes in public health, due to its importance in the evaluation of determinants of populations' health and its role as tools for promoting long-term quality of life.

Mostly, the dietary guidelines used as foundations to develop meal quality indices were quite similar among the different countries. There are aspects that still warrant further research, particularly to the numerous approaches to assessing meals considering different foods and nutrients, and the need for validation studies of the indices designed for the assessment of nutritional quality of meals. Nevertheless, the possibility to have a single indicator developed to the assessment of meal quality, designed to allow the comparison of populational food intake in different countries, should be useful for public health. The comparative analysis of countries at different epidemiological and nutritional stages could bring advances in the development of public policies for the promotion of population health based on food and nutrition initiatives.

\section{References}


1. World Health Organization. Diet, nutrition and the prevention of chronic diseases. (2003). WHO technical report series. (916):1-60.

2. Ocke, M. C. (2013). Evaluation of methodologies for assessing the overall diet: Dietary quality scores and dietary pattern analysis. Proceedings of the Nutrition Society, 72(2), 191-199.

3. Waijers, P. M., Feskens, E. J., \& Ocké, M. C. (2007). A critical review of predefined diet quality scores. British Journal of Nutrition, 97(02), 219-231.

4. Fransen, H. P., \& Ocke, M. C. (2008). Indices of diet quality. Curr Opin Clin Nutr Metab Care, 11(5), 559-565.Hedderley, D. I., \& Meiselman, H. L. (1995). Modelling meal acceptability in a free choice environment. Food quality and preference, 6(1), 15-26.

5. Hedderley, D. I., \& Meiselman, H. L. (1995). Modelling meal acceptability in a free choice environment. Food quality and preference, 6(1), 15-26.

6. Oltersdorf, U., Schlettwein-Gsell, D., \& Winkler, G. (1999). Assessing eating patterns - an emerging research topic in nutritional sciences: Introduction to the symposium. Appetite, 32(1), 1-7.

7. Rozin, P. (2005). The meaning of food in our lives: a cross-cultural perspective on eating and well-being. Journal of nutrition education and behavior, 37, S107-S112.

8. Hearty, A. P., \& Gibney, M. J. (2008). Analysis of meal patterns with the use of supervised data mining techniques--artificial neural networks and decision trees. Am J Clin Nutr, 88(6), 1632-1642. 
9. Leech, R.M., Worsley, A., Timperio, A. \& McNaughton, S.A. (2015). Characterizing eating patterns: a comparison of eating occasion definitions. The American journal of clinical nutrition, 102, 1229-1237.

10. Meiselman, H. L. (2008). Dimensions of the meal. Journal of foodservice, 19(1), 13-21.

11. Costa, A. I. d. A., Schoolmeester, D., Dekker, M., \& Jongen, W. M. (2007). To cook or not to cook: a means-end study of motives for choice of meal solutions. Food Quality and Preference, 18(1), 77-88.

12. Fjellström, K. (2008). Mealtime and meal patterns from a cultural perspective. Food \& Nutrition Research, 48(4), 161-164.

13. Popkin, B. M., \& Duffey, K. J. (2010). Does hunger and satiety drive eating anymore? Increasing eating occasions and decreasing time between eating occasions in the United States. The American journal of clinical nutrition, 91(5), 1342-1347.

14. Leech, R. M., Worsley, A., Timperio, A., \& McNaughton, S. A. (2015). Understanding meal patterns: definitions, methodology and impact on nutrient intake and diet quality. Nutrition research reviews, 1-21.

15. Brasil. Ministério da Saúde. Secretaria de Atenção à Saúde. Departamento de Atenção Básica. (2014). Guia alimentar para a população brasileira. Brasília: Ministério da Saúde.

16. Ruel, M. T. (2003). Operationalizing dietary diversity: a review of measurement issues and research priorities. J Nutr, 133(11 Suppl 2), 3911s$3926 s$. 
17. Kourlaba, G., \& Panagiotakos, D. B. (2009). Dietary quality indices and human health: A review. Maturitas, 62(1), 1-8.

18. Santos, C. M. d. C., Pimenta, C. A. d. M., \& Nobre, M. R. C. (2007). The PICO strategy for the research question construction and evidence search. Revista latino-americana de enfermagem, 15(3), 508-511.

19. Guenther, P. M., Reedy, J., Krebs-Smith, S. M., \& Reeve, B. B. (2008). Evaluation of the healthy eating index-2005. Journal of the American Dietetic Association, 108(11), 1854-1864.

20. Higgins, J. P., \& Green, S. (2008). Cochrane handbook for systematic reviews of interventions (Vol. 5): Wiley Online Library.

21. Moher, D., Liberati, A., Tetzlaff, J., \& Altman, D. G. (2009). Preferred reporting items for systematic reviews and meta-analyses: the PRISMA statement. Annals of internal medicine, 151(4), 264-269.

22. Chien, P. F., Khan, K. S., \& Siassakos, D. (2012). Registration of systematic reviews: PROSPERO. BJOG: An International Journal of Obstetrics \& Gynaecology, 119(8), 903-905.

23. Bandoni, D. H., \& Jaime, P. C. (2008). The quality of meals in companies participating in the workers food program in the city of São Paulo, Brazil. Rev. nutr, 21(2), 177-184.

24. Sampaio Moreira Barbosa, R., Serrão Lanzillotti, H., \& Henriques, P. (2014). Reproducibility study of the meal quality index. Revista Chilena de Nutricion, 41(1), 72-76.

25. van den Boom, A., Serra-Majem L Fau - Ribas, L., Ribas L Fau - Ngo, J., Ngo J Fau - Perez-Rodrigo, C., Perez-Rodrigo C Fau - Aranceta, J., Aranceta 
J Fau - Fletcher, R., et al. (2006). The contribution of ready-to-eat cereals to daily nutrient intake and breakfast quality in a Mediterranean setting. (07315724 (Print)).

26. Monteagudo, C., Palacin-Arce, A., Bibiloni Mdel, M., Pons, A., Tur, J. A., Olea-Serrano, F., et al. (2013). Proposal for a Breakfast Quality Index (BQI) for children and adolescents. Public Health Nutr, 16(4), 639-644.

27. Lassen, A. D., Biltoft-Jensen, A., Hansen, G. L., Hels, O., \& Tetens, I. (2010). Development and validation of a new simple Healthy Meal Index for canteen meals. Public Health Nutr, 13(10), 1559-1565.

28. Sabinsky, M. S., Toft, U., Andersen, K. K., \& Tetens, I. (2012). Development and validation of a Meal Index of dietary Quality (Meal IQ) to assess the dietary quality of school lunches. Public health nutrition, 15(11), 2091-2099.

29. Wissing, U., Lennernas, M. A. C., Ek, A. C., \& Unosson, M. (1998). Monitoring of dietary quality in outpatients by qualitative meal classification method. Journal of Human Nutrition and Dietetics, 11(2), 125-133.

30. Fulkerson, J. A., Lytle, L., Story, M., Moe, S., Samuelson, A., \& Weymiller, A. (2012). Development and validation of a screeninginstrument to assess the types and quality offoods served at home meals [Electronic Version]. International Journal of Behavioral Nutrition and Physical Activity, 9, 1-7,

31. Shaw, A. M., Fulton, L., Davis, C., \& Hogbin, M. (2001). Using the food guide pyramid: a resource for nutrition educators: Oklahoma State Department of Education. 
32. Mithril, C., Dragsted, L. O., Meyer, C., Tetens, I., Biltoft-Jensen, A., \& Astrup, A. (2013). Dietary composition and nutrient content of the New Nordic Diet. Public health nutrition, 16(05), 777-785.

33. Martnez, E., Llull, R., Del Mar Bibiloni, M., Pons, A., \& Tur, J. A. (2010). Adherence to the mediterranean dietary pattern among balearic islands adolescents. British Journal of Nutrition, 103(11), 1657-1664.

34. Brasil. Ministério da Saúde. Secretaria de Atenção à Saúde. Departamento de Atenção Básica. (2006). Guia alimentar para a população brasileira: promovendo a alimentação saudável. Brasília: Ministério da Saúde.

35. Barbieri, H. E., Lindvall, C., \& Livsmedelsverket, S. (2005). Swedish Nutrition Recommendations Objectified (SNO): Basis for General Advice on Food Consumption for Healthy Adults: Livsmedelsverket.

36. Navia, B., \& Ortega, R. (2000). Ingestas recomendadas de energía y nutrientes. Nutriguía. Manual de nutrición clínica en atención primaria. Madrid. Editorial Complutense, 3-13.

37. World Health Organization. (1990). Diet, nutrition and the prevention of chronic diseases: World Health Organization Geneva.

38. Murakami K, \& Livingstone MB. (2015). Associations between meal and snack frequency and diet quality and adiposity measures in British adults: findings from the National Diet and Nutrition Survey. Public health nutrition, 15:6:1-11.

39. Nardo, M., Saisana, M., Saltelli, A., Tarantola, S., Hoffman, A., \& Giovannini, E. (2005). Handbook on constructing composite indicators: methodology and user guide: OECD publishing. 
40. Jaime, P.C., Bandoni, D.H., Duran, A.C.F.L., Fisberg, R.M. (2010). Diet quality index adjusted for energy requirements in adults. Cad Saúde Pública, 26(11):2121- 2128 .

\title{
5.2. DESENVOLVIMENTO DO INDICADOR
}

\subsubsection{MANUSCRITO 2}

Measuring the quality of main meals: development and validation of a meal quality index

B. M. Gorgulho, G. K. Pot, F. M. Sarti, R. M. Fisberg, D. M. Marchioni Artigo científico aceito para publicação no British Journal of Nutrition.

\begin{abstract}
Despite the fact that individuals usually organize their dietary intakes by combining foods into meals, investigations of the quality of main meals and their potential impacts on health and disease are scarce. The objectives of this study are to propose an index to assess the nutritional quality of main meals and to evaluate its internal validity and reliability. The Main Meal Quality Index (MMQI), based on international dietary recommendations, includes ten components of equal weight: fruits, vegetables (excluding potatoes), ratio of animal protein/total protein, fibre, carbohydrate, total fat, saturated fat, processed meats, sugary beverages and desserts, and energy density. The final scores range from 0-100 points. Dietary data were based on $24 \mathrm{H}$ recalls from a cross-sectional, population-based survey of 936 adolescents and adults living in the city of São Paulo in southeastern Brazil in 2008.
\end{abstract}


The MMQI was positively associated with carbohydrate, vegetable protein, fibre, vitamins $\mathrm{A}, \mathrm{E}, \mathrm{K}$ and $\mathrm{C}$, folate and potassium and negatively associated with energy intake, total fat, saturated fat, animal protein, cholesterol, phosphorus, sodium, added sugar, and cholesterol biomarkers. Cronbach's alpha was 0.70 , and significant differences were found between two groups with known, marked disparities in dietary quality, smokers (50.2 points) and non-smokers (53.5 points). When tested on the sample, the MMQI presented good internal reliability and validity for use as an instrument for evaluating, monitoring and comparing main meal quality.

Key words: meal quality, meal pattern, dietary quality, meal index, meal score

\section{Introduction}

Various studies have shown that food consumption patterns referring to main meals are associated with lifestyle factors, food choices and nutrient intake $e^{(1,2)}$ and influence both quantity and quality of dietary intake, especially regarding bioavailability of certain nutrients. However, a recent review of meal patterns research showed a lack of consistency and standardization among studies examining meals, as well as their determinants and consequences. This inadequate research may be particularly important due to preliminary evidence of a link between the timing of dietary intake and cardiometabolic risk, thus improving our knowledge of dietdisease relationships. ${ }^{(2)}$

Meals are eating occasions that are essential to several aspects of human life: they not only provide nutrients and energy at the biological level but also embed 
cultural and socioeconomic dimensions at the societal level. ${ }^{(3-6)}$ Eating occasions could be defined based on their nutrient content; they are main meals when they provide at least $30 \%$ of daily recommended nutritional intake, ${ }^{(7)}$ such as lunch or dinner (depending on the country), ${ }^{(5)}$ while a smaller eating occasion is considered a snack. $^{(2)}$

Due to the complexity of diet and the potential for interactions among dietary components, approaches focusing on single food items or nutrients may overlook interactions between dietary habits and disease aetiologies. ${ }^{(8,9)}$ Since the 1990s, several dietary quality indices have been developed in order to create an instrument with the ability to synthesize and score the nutritional quality of diet, enabling the identification and tracking of changes over time and the comparison of populations. ${ }^{(10,11)}$ Despite the fact that food choices are based on combinations of foods organized into meals, the vast majority of dietary quality indices focus on overall dietary intake over the long term.

Few studies have investigated meal quality indicators, ${ }^{(2)}$ and these have focused on meal frequency, spacing, skipping and timing. ${ }^{(2)}$ Furthermore, a crossover trial showed that modification of a single meal could be sufficient to provoke health benefits, observing that isocaloric meals with distinct compositions elicit different postprandial inflammatory responses. ${ }^{(12)}$

Thus, the creation of an index that synthesizes the quantitative and qualitative aspects of main meal nutritional composition may support the standardization of nutritional guidelines for populations and assist with the execution of innovative 
research on food consumption patterns. Meal-based approaches are valuable complements to dietary advice, assisting populations in meeting their recommended daily intakes ${ }^{(2)}$. Therefore, the aims of this study were to develop an index of the nutritional quality of main meals in accordance with nutritional recommendations and to evaluate the validity and reliability of the proposed index.

\section{Methods}

Main Meal Quality Index (MMQI)

The Main Meal Quality Index (MMQI) includes ten components: fruits (in grams), vegetables (excluding potatoes, in grams), animal protein/total protein ratio, total dietary fibre (in grams), carbohydrate ( $\%$ of energy), total fat ( $\%$ of energy), saturated fat ( $\%$ of energy), processed meats (number of portions), sugary beverages and desserts (number of portions), and energy density. Each component is assigned between zero and 10 points, resulting in a final score of $0-100$ points. The scoring system was based on international guidelines ${ }^{(12,13)}$, and the cut-off points for the maximum, intermediate, and minimum scores were based on the proportion of daily recommendations proposed by the World Health Organization (WHO) and the World Cancer Research Fund (WCRF) ${ }^{(13,14)}$. The components and the scoring system are presented in table 1.

Grams of Fruits and vegetables (excluding potatoes) 
Based on a daily recommended intake of $400 \mathrm{~g} /$ day $^{(14)}$ of fruit and vegetables (equivalent to five portions per day), a main meal should provide at least one portion of fruit (80 g) and two portions of vegetables (160 g).

Table 1. Main Meal Qulity Index components and standards for scoring.

\begin{tabular}{lccc}
\hline Component & Maximum points & $\begin{array}{c}\text { Standard for } \\
\text { maximum score* }\end{array}$ & $\begin{array}{c}\text { Standard for minimum } \\
\text { score of zero* }\end{array}$ \\
\hline Fruit & 10 & $\geq 80 \mathrm{~g}$ & $\leq 0 \mathrm{~g}$ \\
Vegetable (excluded potato) & 10 & $\geq 160 \mathrm{~g}$ & $\leq 80 \mathrm{~g}$ \\
Animal protein/total protein & 10 & $\leq 80 \%$ & $100 \%$ \\
Fiber & 10 & $\geq 10 \mathrm{~g}$ & $\leq 7 \mathrm{~g}$ \\
Carbohydrate & 10 & $\geq 55 \%$ of total energy & $\leq 40 \%$ of total energy \\
Total fat & 10 & $\leq 30 \%$ of total energy & $\geq 40 \%$ of total energy \\
Satured fat & 10 & $\leq 10 \%$ of total energy & $\geq 13 \%$ of total energy \\
Processed meat & 10 & 0 portion & $\geq 1$ portion \\
Sugary beverages and & 10 & 0 portion & $\geq 1$ portion \\
desserts & 10 & $\leq 1.25 \mathrm{kcal} / \mathrm{g}$ & $\geq 1.65 \mathrm{kcal} / \mathrm{g}$ \\
Energy density & & & \\
\hline
\end{tabular}

* For intermediates values were given a score proportional to the amount consumed.

\section{Animal protein/total protein ratio}

Based on recommendations to limit daily intake of meat and increase vegetable consumption, ${ }^{(13)}$ at least $20 \%$ of total protein consumed should be from vegetable sources. This percentage is equivalent to one daily portion of legumes (55 kcal) or half a portion in a main meal.

\section{Grams of fibre}

Based on an average daily recommended intake of at least $25 \mathrm{~g} /$ day of nonstarch polysaccharides, a main meal should provide at least $10 \mathrm{~g}$ of total dietary fibre 
14. Non-starch polysaccharides include all plant polysaccharides other than starch. These are present, for example, in whole grains, fruits and vegetables.

Energy intake from carbohydrate, total fat and saturated fat

These items express the percentage of calories from carbohydrate, total fat and saturated fat consumed in relation to the total energy provided by the meal. Total carbohydrates should provide between $55 \%$ and $75 \%$ of total energy intake, total fat between $15 \%$ and $30 \%$ of total energy intake, and saturated fat than $10 \%$ of total energy intake. ${ }^{(14)}$

Portions of processed meats and sugary beverages and desserts

These components indicate the predominant types of meats and the presence or absence of added sugar consumed in the meal. There are general guidelines recommend avoiding significant intakes of foods and drinks that promote the development of non-communicable chronic diseases, ${ }^{(13)}$ especially food items high in salt, fat and added sugar.

Energy density of the meal

Guidelines recommend avoiding diets with energy density higher than 1.25 $\mathrm{kcal} / \mathrm{g} ;{ }^{(13)}$ thus, this component allows the analysis of the energy density of the meal.

Sample for testing and evaluation of the MMQI

The data were obtained from a cross-sectional survey of health and living conditions conducted (Inquéritos de Saúde de São Paulo-ISA 2008) using a 
representative sample of individuals living in the city of São Paulo (in southeastern Brazil) in 2008. These data were used to assess the internal validity and reliability of the MMQI. Briefly, the sample consisted of urban dwellers living in private or collective households in the municipality of São Paulo. The participants were selected using two-stage stratified cluster sampling in order to assure representativeness. The primary sampling units were urban census tracts, and the secondary units were households. ${ }^{(15)}$ Data collection was performed over 12 months starting in 2008, and individuals were interviewed at home to collect data on life habits and sociodemographic conditions. In addition, a subsample was invited to donate a blood sample for biochemical analyses. For each potential participant, up to five attempts were made to contact them for an interview; after five unsuccessful attempts, individuals were classified as having refused to be interviewed. The ISA 2008 study has been described in detail. ${ }^{(15)}$

Food intake was registered using a 24-hour dietary recalls administered by trained interviewers according to the Multiple-Pass Method. ${ }^{(16)}$ The Multiple-Pass Method is a 5-step dietary interview that helps individuals recall the foods and beverages they consumed the day before the interview and records them in detail, thus reducing dietary measurement errors. ${ }^{(16)}$

The dietary information collected was converted into measurement units, and nutritional assessment was performed using the Nutrition Data System for Research software (NDS-R, 2007 version, University of Minnesota). The primary source of nutritional composition of foods was the U.S. Department of Agriculture (USDA) nutritional composition table, followed by information provided on food labels and 
in the scientific literature. The USDA food composition table was compared with the Brazilian table, and the nutritional values were standardized, taking as a base percentage of agreement between $80 \%$ to $120 \%$ for energy and macronutrients. ${ }^{(17)}$

Meals were self-reported as breakfast, lunch, dinner or snacks in the interviews, and the meal with highest caloric contribution of the day (lunch, in this population) was defined as the main meal. ${ }^{(2,5,7,18)}$ Although the ISA 2008 sample includes 1440 individuals, this study considered a sample of 956 individuals (332 adolescents, 350 adults and 274 older adults) of both genders, including only those who had consumed lunch the day before the interview. Of those subjects, 580 (24\% of adolescents, $36 \%$ of adults and $40 \%$ of older adults) provided a blood sample.

The project was approved by a Research Ethics Committee, and all participants provided written informed consent.

\section{Data Analysis}

The performance of the MMQI was measured using statistical strategies for assessing content validity, construct validity, discriminant validity and reliability. Some of these strategies were based on those used by Guenther et al used to evaluate the Healthy Eating Index-2005 (2008) ${ }^{(19)}$.

\section{Construct validity}

Correlations between MMQI scores and the following nutrients were evaluated: energy $(\mathrm{kcal})$, fat $(\mathrm{g})$, protein $(\mathrm{g})$, carbohydrate $(\mathrm{g})$, animal protein $(\mathrm{g})$, vegetable protein $(\mathrm{g})$, fibre $(\mathrm{g})$, saturated fat $(\mathrm{g})$, cholesterol $(\mathrm{mg})$, vitamin A (RE), 
vitamin C (mg), vitamin E (mg), vitamin K (mcg), riboflavin (mg), niacin (mg), vitamin B6 (mcg), vitamin B12 (mcg), total folate (mcg), iron (mg), phosphorus (mg), zinc (mg), calcium (mg), potassium (mg), sodium (mg) and added sugar (g).

Associations between MMQI scores and various plasma biomarkers were performed using bivariate linear regression models. The following biomarkers were tested for correlations: total cholesterol $(\mathrm{mg} / \mathrm{dL})$, high-density lipoprotein (HDL) cholesterol (mg/dL), low-density lipoprotein (LDL) cholesterol (mg/dL), triglycerides $(\mathrm{mg} / \mathrm{dL})$, fasting glucose $(\mathrm{mg} / \mathrm{dL})$ and homocysteine $(\mu \mathrm{mol} / \mathrm{L})$.

\section{Reliability}

Cronbach's alpha coefficients were used to determine the internal consistency of the MMQI components, describing the extent to which all the items in a test measure the same concept or construct; hence, this value indicates the interrelatedness of the items within the test. ${ }^{(20)}$ Higher Cronbach's alpha values indicate greater reliability of the proposed scale, and an increase in the reliability of the estimation indicates a decrease the fraction of a test score that is attributable to error. $^{(21)}$

Associations with overall dietary quality

The correlations between MMQI scores and overall dietary quality were explored using linear regression models adjusted for gender, age and energy. Overall dietary quality was assessed using the Brazilian Healthy Eating Index Revised (BHEIR). ${ }^{(22)}$ The B-HEIR components are based on the Dietary Guidelines for the 
Brazilian Population, ${ }^{(23)}$ expressed in terms of caloric density $(1,000 \mathrm{kcal} / \mathrm{g})$. The following scores are assigned for the intake of each B-HEIR component: 5 points for total grains, whole grains, dark green and orange vegetables and beans, total vegetables, total fruit and whole fruits; 10 points for dairy products, meat and beans, oils, saturated fat, and sodium; and 20 points for total calories from solid fat, alcohol and added sugar.

Subgroup analysis

Average scores for the MMQI and its components were compared for smokers and non-smokers adults (Wald's test) to determine whether the index could distinguish between groups with known differences in dietary quality.

The analyses were performed using Stata statistical software (Stata Corp., version 13, College Station), and a significance level of 5\% was used.

\section{Results}

The characteristics of the study population are described in Table 2. The average energy content of lunch was $918 \pm 19.18 \mathrm{kcal}$.

The MMQI scores were normally distributed $(p=0.66)$ and were positively associated with the following nutrients: carbohydrate, vegetable protein, fibre, vitamins $\mathrm{A}, \mathrm{E}, \mathrm{K}$ and $\mathrm{C}$, folate and potassium. Energy intake, total fat, saturated fat, animal protein, cholesterol, phosphorus, sodium and added sugar were negatively associated with MMQI scores (Table 3). Additionally, a negative association between the MMQI score and total plasma cholesterol (adjusted for gender and age) 
was observed $(\beta=-0.004 ; \mathrm{p}=0.04)$, although for the other biomarkers, HDL cholesterol, LDL cholesterol, triglycerides, fasting glucose and homocysteine, we observed no statistically significant associations.

Table 2. Characteristics of the individuals and the MMQI score. Sao Paulo, Brazil (2008).

\begin{tabular}{|c|c|c|c|c|c|c|}
\hline & \multicolumn{2}{|c|}{ Individuals } & \multicolumn{4}{|c|}{ MMQI } \\
\hline & $\mathrm{n}$ & $\%$ & Mean & SEM $^{\mathrm{a}}$ & $95 \%$ Con & Interval \\
\hline \multicolumn{7}{|l|}{ Gender } \\
\hline men & 493 & 52 & 52.84 & 0.92 & 51.02 & 54.65 \\
\hline women & 463 & 48 & 53.51 & 0.94 & 51.65 & 55.36 \\
\hline \multicolumn{7}{|l|}{ Age } \\
\hline Adolescent (12-18 years) & 332 & 35 & 51.24 & 1.04 & 49.18 & 53.30 \\
\hline Adult (19-59 years) & 350 & 36 & 52.10 & 1.09 & 49.96 & 54.24 \\
\hline Elderly (60 years or more) & 274 & 29 & 56.85 & 1.30 & 54.28 & 59.41 \\
\hline \multicolumn{7}{|l|}{ Nutritional status } \\
\hline underweight & 79 & 8 & 50.47 & 2.40 & 45.68 & 55.25 \\
\hline normal weight & 475 & 50 & 52.79 & 0.88 & 51.06 & 54.52 \\
\hline overweight & 260 & 27 & 54.55 & 1.31 & 51.97 & 57.13 \\
\hline obese & 142 & 15 & 53.37 & 1.89 & 49.64 & 57.10 \\
\hline \multicolumn{7}{|l|}{ Cigarette } \\
\hline Somokers & 312 & 33 & 50.21 & 0.12 & 47.80 & 52.62 \\
\hline Nonsmokers & 643 & 67 & 53.51 & 0.10 & 51.42 & 55.60 \\
\hline \multicolumn{7}{|l|}{ Family income per member* } \\
\hline Up to two minimum salaries & 873 & 92 & 53.44 & 0.68 & 52.11 & 54.78 \\
\hline 3-6 minimum salaries & 70 & 7 & 49.34 & 4.09 & 40.95 & 57.74 \\
\hline 6 or more minimum salaries & 10 & 1 & 50.65 & 3.27 & 44.08 & 57.22 \\
\hline
\end{tabular}


Table 3. Association between MMQI and nutrients consumed at lunch.

Sao Paulo, Brazil (2008).

\begin{tabular}{|c|c|c|c|c|}
\hline Nutrient & $\beta$ & $95 \%$ & & $\mathrm{p}$ \\
\hline Energy (Kcal) & -0.0007 & -0.0009 & -0.0004 & $<0.0010$ \\
\hline Total fat (g) & -0.0361 & -0.0411 & -0.0312 & $<0.0010$ \\
\hline Crbohydrate (g) & 0.0140 & 0.0115 & 0.0167 & $<0.0010$ \\
\hline Protein $(g)$ & -0.0129 & -0.0170 & -0.0087 & $<0.0010$ \\
\hline Animal protein (g) & -0.0187 & -0.0228 & -0.0146 & $<0.0010$ \\
\hline Vegetable protein $(\mathrm{g})$ & 0.1593 & 0.1389 & 0.1796 & $<0.0010$ \\
\hline Cholesterol (mg) & -0.0044 & -0.0054 & -0.0034 & $<0.0010$ \\
\hline Satured fat (g) & -0.1150 & -0.1286 & -0.1014 & $<0.0010$ \\
\hline Fiber $(\mathrm{g})$ & 0.2503 & 0.2252 & 0.2754 & $<0.0010$ \\
\hline Vitamin A (RE) & 0.0014 & 0.0001 & 0.0002 & $<0.0010$ \\
\hline Vitamin E (mg) & 0.2668 & 0.1947 & 0.3389 & $<0.0010$ \\
\hline Vitamin K (mcg) & 0.0029 & 0.0019 & 0.0039 & $<0.0010$ \\
\hline Vitamin C (mg) & 0.0058 & 0.0045 & 0.0071 & $<0.0010$ \\
\hline Thiamin (mg) & -0.1681 & -0.4317 & -0.0954 & 0.2110 \\
\hline Riboflavin (mg) & -0.1853 & -0.3689 & -0.0007 & 0.0500 \\
\hline Niacin (mg) & -0.0037 & -0.0204 & -0.0130 & 0.6670 \\
\hline Vitamin B6 (mcg) & 0.2104 & -0.0239 & 0.4448 & 0.0780 \\
\hline Vitamin B12 (mcg) & -0.0028 & -0.01427 & -0.0086 & 0.6280 \\
\hline Total folate (mcg) & 0.0062 & 0.0051 & 0.0074 & $<0.0010$ \\
\hline Iron (mg) & 0.0087 & -0.0247 & 0.0421 & 0.6120 \\
\hline Phosphorus (mg) & -0.0010 & -0.0015 & -0.0006 & $<0.0010$ \\
\hline Zinc (mg) & 0.0067 & -0.2161 & 0.0350 & 0.6420 \\
\hline Calcium (mg) & 0.0003 & -0.0007 & 0.0013 & 0.5680 \\
\hline Potassium (mg) & 0.0006 & 0.0004 & 0.0008 & $<0.0010$ \\
\hline Sodium (mg) & -0.0002 & -0.0003 & -0.0001 & 0.0020 \\
\hline Added sugar (g) & -0.0089 & -0.0139 & -0.0038 & 0.0010 \\
\hline
\end{tabular}

* Linear regression between MMQI and each nutrient adjusted by gender and age.

$\mathrm{n}=956$

The analysis of differences in food intake quality between smokers and nonsmokers revealed that the final scores were lower for smokers (50.2 points) compared with non-smokers (53.5 points), showing a significant difference between the groups $(\mathrm{p}<0.01)$. Furthermore, Cronbach's alpha was 0.70 , and there were weak 
correlations between most components' scores; strong correlations were observed between total fat and carbohydrate (0.68) and between total fat and saturated fat (0.73).

The MMQI score was significantly associated with age, energy and overall dietary quality (B-HEIR) in bivariate models (table 4). Even after adjusting for age, gender and energy intake, main meal quality remained associated with overall dietary quality $(\mathrm{P}<0.001)$.

Table 4. Association between MMQI and revised version of the Healthy Eating Index for the Brazilian population (HEI-B). Sao Paulo, Brazil (2008).

\begin{tabular}{|c|c|c|c|c|}
\hline & \multicolumn{4}{|c|}{ Bivariate Model a } \\
\hline & $\beta$ & \multicolumn{2}{|c|}{$95 \% \mathrm{CI}$} & $\mathrm{p}$ \\
\hline \multicolumn{5}{|l|}{ Bivariate Model ${ }^{\mathrm{a}}$} \\
\hline \multicolumn{5}{|c|}{ Demographic covariates } \\
\hline Gender & 0.0665 & -0.1928 & 0.3259 & 0.615 \\
\hline Age & 0.0106 & 0.0056 & 0.0166 & $<0.0010$ \\
\hline \multicolumn{5}{|l|}{ Dietary covariates } \\
\hline Energy intake & -0.0001 & -0.0012 & -0.0007 & $<0.0010$ \\
\hline HEI-B & 0.079 & 0.069 & 0.089 & $<0.0010$ \\
\hline \multicolumn{5}{|l|}{ Model I $\mathrm{I}^{\mathrm{b}}$} \\
\hline HEI-B & 0.08 & 0.0692 & 0.0909 & $<0.0010$ \\
\hline
\end{tabular}

\section{Discussion}

The objective of this research was to develop an indicator of the nutritional quality of main meals, the Main Meal Quality Index (MMQI), which showed good 
reliability and validity and was correlated with serum cholesterol in this Brazilian population.

A series of systematic reviews on the relationship between dietary patterns and health outcomes conducted by the Nutrition Evidence Library of the United States Department of Agriculture (USDA) concluded that consensus on a single dietary index applicable across populations and health outcomes is needed. ${ }^{(24)}$

Despite cultural and social differences, countries and international organizations have developed nutritional reference values and guidelines with the aim of maintaining health status and preventing increases in the prevalence of dietrelated, non-communicable chronic diseases. Such guidelines consistently recommend high consumption of whole grains, fruits and vegetables, with associated reductions in total fat, saturated fat and added sugar. ${ }^{(13,14,23,25)}$ Accordingly, the MMQI is based on international dietary guidelines. ${ }^{(13,14)}$ Although this study used data only from Sao Paulo, the idea was propose an indicator that could be further validated using other samples without modifying its components.

Of the ten components included in the MMQI, four were food groups, five were nutrients and one was energy density. Each component of the indicator scored between 0 and 10 points. The components of the MMQI were not weighted, and the final scores ranged from 0 to 100 points. This score range allowed sufficient ranking of individuals in a population. ${ }^{(26)}$ Rather than focusing on foods that are specific or traditional to the Brazilian diet, such as beans, nutrients and food groups that are usually present in national and international nutritional recommendations were 
selected. This choice allows the comparison of main meals consumed by different populations. $^{(27)}$

The first overall diet quality indexes proposed were the Dietary Quality Index (1994) ${ }^{(28)}$ and the Healthy Eating Index (HEI) (1995). ${ }^{(29)}$ The HEI was revised in 2005 (HEI-2005) ${ }^{(26)}$ and adapted in 2010 (HEI-2010); this latest version is still used by the USDA. ${ }^{(30)}$ The analyses performed in this paper to evaluate the validity and the reliability of the MMQI used an approach similar to that used to evaluate the HEI-2005, HEI-2010 ${ }^{(19,30)}$ and HEI-2005 adapted for the Brazilian population (BHEIR). ${ }^{(31)}$

The results showed desirable measurement properties (reliability and validity) when used to evaluate the quality of meals consumed by our representative sample of the largest Brazilian city. Cronbach's alpha for the MMQI was higher than the HEI2005 coefficient $^{(19)}$ and similar to the B-HEIR ${ }^{(31)}$ and HEI-2010 coefficients. ${ }^{(30)}$

Cronbach's alpha showed internal consistency of the components included in the MMQI. Values equal to or greater than 0.6 are considered to indicate acceptable reliability. ${ }^{(32)}$ Furthermore, the indicator was able to identify statistically significant differences between group with marked and known disparities in dietary quality (smokers and non-smokers), as previously described in the literature. ${ }^{(33)}$

The meal quality indicator was positively related to overall dietary quality (regardless of gender, age and energy content) and was negatively associated with total serum cholesterol (regardless of gender and age). In fact, higher MMQI scores represented higher nutritional quality of the meal consumed. The final score was 
positively associated with nutrients related to healthy diets (fibre and vitamins A, E, $\mathrm{K}$ and $\mathrm{C}$ ) and negatively associated with nutrients related to unhealthy diets (fat, saturated fat, cholesterol, sodium and added sugar). ${ }^{(13,14,23,25)}$ Similar associations between dietary quality scores and nutrients have been described in the literature. ${ }^{(30,34,35)}$

There was no association between the MMQI score and thiamine, vitamin B6, vitamin B12, iron, zinc or calcium. These results were expected for the following reasons: (1) in Brazil, food sources of these nutrients (e.g., milk, cereals and nuts) are usually consumed at breakfast or as snacks, and (2) food sources of the nutrients are usually foods of animal origin. The MMQI score prioritizes vegetable sources of protein, penalizing the excessive consumption of animal sources of protein. In Brazil, $74 \%$ of the population habitually consumes red (beef and pork) and processed meats at higher than recommended levels, with an average meat consumption of 157 g/day. ${ }^{(36)}$ The MMQI was developed to evaluate main meals, that is, meals with higher energy content, such as lunch and dinner (or equivalent meals, if other definitions are used). Thus, considering its characteristics, this indicator is not appropriate for studying minor eating events, as breakfast and snacks.

Techniques to evaluate meals have been little explored, and the literature on population-level meal indicators is still scarce. ${ }^{(2,4)}$ To the best of our knowledge, the main meal indicators described have been proposed to evaluate meals offered to specific subjects, making comparison with other groups difficult. A recent systematic review of indicators used to evaluate meal quality ${ }^{(37)}$ retrieved only seven published nutritional indicators, two evaluating breakfast, ${ }^{(38,39)}$ three evaluating lunch or 
dinner $^{(34,40,41)}$ and two evaluating an unspecified meal. ${ }^{(42,43)}$ Three of these were indicators for lunch and dinner developed to evaluate institutional meals offered in schools ${ }^{(34,41)}$ or workplaces. ${ }^{(40)}$ Moreover, although tests of internal consistency are considered essential to determining the indicators' ability to properly measure the desired concept, most studies proposing dietary indices have not engaged in such analyses. ${ }^{(37)}$

The development of a meal quality index is complex, involving a large degree of subjectivity and many choices related to components, cut-off values and scoring. ${ }^{(26)}$ The MMQI scores are not adjusted for energy consumption. However, for epidemiologic analyses, some studies recommend adjusting the final indicator score by energy content. ${ }^{(44)}$ Intakes of most nutrients tend to be positively correlated with total energy consumed, and particularly strong associations for macronutrients are described in the literature. ${ }^{(44)}$ In an attempt to overcome this, the MMQI evaluates the per cent of energy contributed by carbohydrates and fats and includes the energy density of the meal as a component. Foods rich in fibre, vitamins and minerals, such as fruits and vegetables, have lower energy density compared with foods that have higher sugar and fat contents. Furthermore, the avoidance of processed meats and sugary beverages and foods, independent of the energy consumption, is recommended. ${ }^{(13)}$

There is no consensus regarding the best way to validate dietary quality indicators. In this context, we sought to apply the most widely used analysis described in the literature. We believe that an interesting way to validate the MMQI would be an examination of the association between index scores and postprandial 
responses; however, we do not have enough information to conduct such an analysis. Moreover, there are no nutritional recommendations that apply directly to meals; thus, the recommended average number of daily portions must be adapted, which increases the degree of indicator subjectivity.

A limitation of this study is that we relied on dietary data from a single 24hour recall to validate the MMQI. Therefore, usual intakes could not be estimated. ${ }^{(45)}$ However, the mean usual intake of a population of individuals can be obtained if individual questionnaires are collected for every day of the week and across all four seasons of the year, as was the case in the ISA 2008. ${ }^{(45)}$

Further investigations should take steps to validate the MMQI using data from other populations, enabling the comparison of meals consumed by populations in different cultural and social contexts.

\section{Conclusion}

The Main Meal Quality Index we developed exhibited satisfactory internal consistency as an instrument for evaluating, monitoring and comparing the nutritional quality of meals consumed by Brazilians living in São Paulo; however, more studies are needed to evaluate and validate the indicator in other populations. The MMQI was based on dietary guidelines and represented the available evidence of what constitutes a healthy diet, taking into account that diet is composed of foods combinations organized at the meal level.

\section{References}


1. Ocké MC. Evaluation of methodologies for assessing the overall diet: Dietary quality scores and dietary pattern analysis (2013). Proceedings of the Nutrition Society. 72(2):191-199.

2. Hu FB (2002). Dietary pattern analysis: a new direction in nutritional epidemiology. Curr Opin Lipidol. 13(1):3-9.

3. Kant, AK (1996). Indexes of overall diet quality: a review. Journal of the American Dietetic Association, 96(8), 785-791.

4. Fransen, HP, Ocké, MC (2008). Indices of diet quality. Current opinion in clinical nutrition \& metabolic care.11(5), 559-565.

5. Costa A, Schoolmeester D, Dekker M, Jongen WM (2007). To cook or not to cook: a means-end study of motives for choice of meal solutions. Food Quality and Preference.18(1):77-88.

6. Hearty AP, Gibney MJ (2008). Analysis of meal patterns with the use of supervised data mining techniques--artificial neural networks and decision trees. Am J Clin Nutr.88(6):1632-1642.

7. Leech, RM; Worsley, A; Timperio, A; McNaughton, SA (2015). Understanding meal patterns: definitions, methodology and impact on nutrient intake and diet quality. Nutr Research Reviews. DOI:101017/S0954422414000262.

8. Meiselman HL (2008). Dimensions of the meal. Journal of Foodservice. 19(1):13-21.

9. Rozin P (2005). The meaning of food in our lives: a cross-cultural perspective on eating and well-being. Journal of nutrition education and behavior. 37:S107-S112. 
10. Benelam, B; Stanner, S (2015). Development of a methodology to assess the nutrient profile of popular UK meals. Nutrition Bulletin. DOI:101111/nbu. 12167.

11. Monfort-Pires, M., \& Ferreira, S. R. G. (2016). Modification in a single meal is sufficient to provoke benefits in inflammatory responses of individuals at low-to-moderate cardiometabolic risk. Clinical Nutrition.

12. World Cancer Research Fund, American Institute for Cancer Research (2007). Food, nutrition, physical activity, and the prevention of cancer: a global perspective. Washington DC: AICR.

13. World Health Organization (2003). Diet, nutrition and the prevention of chronic diseases. WHO technical report series. (916):1-60.

14. Guenther PM, Reedy J, Krebs-Smith SM, Reeve BB (2008). Evaluation of the Healthy Eating Index-2005. Journal of the American Dietetic Association. 108(11):1854-1864.

15. César CLG, Alves MCGP, Goldbaum M, Segri NJ (2010). Inquéritos de saúde: primeiros resultados. In: CEInfo CdEeI, ed. Vol 1. São Paulo: Secretaria Municipal da Saúde de São Paulo; 03-28.

16. Moshfegh AJ, Rhodes DG, Baer DJ, et al.(2008). The US Department of Agriculture Automated Multiple-Pass Method reduces bias in the collection of energy intakes. The American journal of clinical nutrition. 88(2):324-332.

17. Gatenby SJ (1997). Eating frequency: methodological and dietary aspects. British Journal of Nutrition. 77(S1):S7-S20.

18. Cronbach LJ (1951). Coefficient alpha and the internal structure of tests. psychometrika. 16(3):297-334. 
19. Santos JRA (1999). Cronbach's alpha: A tool for assessing the reliability of scales. Journal of extension. 37(2):1-5.

20. Previdelli AN, Andrade SC, Pires MM, Ferreira SR, Fisberg RM, Marchioni DM (2011). A revised version of the Healthy Eating Index for the Brazilian population. Rev Saude Publica. 45(4):794-798.

21. Brasil (2006). Ministério da Saúde. Secretaria de Atenção à Saúde. Departamento de Atenção Básica. Guia alimentar para a população brasileira: promovendo a alimentação saudável. MS Brasília.

22. U.S. departament of Agriculture (2015). A Series of Systematic Reviews on the Relantioship Between Dietary Patterns and Health Outcomes. Center for Nutrition Policy and Promotion.USDA.

23. Montagnese, C, Santarpia, L, Buonifacio, M, Nardelli, A, Caldara, AR, et al. (2015). European food-based dietary guidelines: A comparison and update. Nutrition. 31:908-915.

24. Mc Naughton, SA (2010). Dietary petterns and diet quality: approaches to assessing complex exposures in nutrition. Australian Epidemiologist,17(1):35-37.

25. Waijers PM, Feskens EJ, Ocké MC (2007). A critical review of predefined diet quality scores. British Journal of Nutrition. 97(02):219-231.

26. Guenther, PM, Reedy, J, Krebs-Smith, SM, Reeve, BB, Basiotis, PP (2007). Development and evaluation of the healthy eating index-2005. United States. Department of Agriculture. Center for Nutrition Policy and Promotion. 
27. Guenther PM, Casavale KO, Reedy J, et al. (2013). Update of the Healthy Eating Index: HEI-2010. Journal of the Academy of Nutrition and Dietetics. 113(4):569-580.

28. Sabinsky MS, Toft U, Andersen KK, Tetens I (2012). Index of dietary Quality (Meal IQ) to assess the dietary quality of school lunches. Public health nutrition. 15(11):2091-2099.

29. Gorgulho, BM, Lipi, M, Marchioni, DML (2001). Nutritional quality of meals served by the cafeteria of a company located in the metropolitan region of São Paulo, Brazil. Revista de Nutrição, 24(3), 463-472.

30. Monteagudo, C., Palacin-Arce, A., Bibiloni Mdel, M., Pons, A., Tur, J. A., Olea-Serrano, F., et al. (2013). Proposal for a Breakfast Quality Index (BQI) for children and adolescents. Public Health Nutr, 16(4), 639-644.

31. Van den Boom, A., Serra-Majem, L., Ribas, L., Ngo, J., Pérez-Rodrigo, C., Aranceta, J., \& Fletcher, R (2006). The contribution of ready-to-eat cereals to daily nutrient intake and breakfast quality in a Mediterranean setting. Journal of the American College of Nutrition, 25(2), 135-143.

32. Bandoni DH, Jaime PC (2008). The quality of meals in companies participating in the worker's food program in the city of São Paulo, Brazil. Rev. nutr. 21(2):177-184.

33. Lassen AD, Biltoft-Jensen A, Hansen GL, Hels O, Tetens I (2010). Development and validation of a new simple Healthy Meal Index for canteen meals. Public Health Nutr. 13(10):1559-1565. 
34. Fulkerson, J. A., Lytle, L., Story, M., Moe, S., Samuelson, A., Weymiller, A (2012). Development and validation of a screeninginstrument to assess the types and quality offoods served at home meals. International Journal of Behavioral Nutrition and Physical Activity, 9, 1-7.

35. Wissing, U., Lennernas, M. A. C., Ek, A. C., Unosson, M (1998). Monitoring of dietary quality in outpatients by qualitative meal classification method. Journal of Human Nutrition and Dietetics, 11(2), 125-133.

36. Willett WC, McCullough ML (2008). Dietary pattern analysis for the evaluation of dietary guidelines. Asia Pac J Clin Nutr. 17 Suppl 1:75-78.

37. Thompson FE, Kirkpatrick SI, Subar AF, Reedy J, Schap TE, Wilson MM, Krebs-Smith SM (2015). The National Cancer Institute's Dietary Assessment Primer: A Resource for Diet Research. Jour of the Acad of Nutr and Diet; 115(12): 1986-1995.

\title{
5.3. AVALIAÇÃO E COMPARAÇÃO DA REFEIÇÃO
}

\subsubsection{MANUSCRITO 3}

Main Meal Quality in Brazil and United Kingdom: Similarities and Differences

B. M. Gorgulho, G. K. Pot, F. M. Sarti, D. M. Marchioni

\begin{abstract}
Consumption of fast food and ready-to-eat meals has been positively associated with obesity. In UK ready-meals are more consumed than in Brazil, a country in nutrition
\end{abstract}


transition, is relatively low. This study aims to compare the nutritional quality of the main meal consumed by adults in Brazil and UK. The characterization of meals, analyses of dietary quality and association with the nutritional status were carried out in databases with representative samples of Brazil and UK. In both studies, food consumption was measured by means of food records. The Main Meal Quality Index (MMQI) was applied to estimate the quality of the main meal consumed in Brazil and in UK. Differences in food groups consumed in the main meal in Brazil and UK were observed using the classification decision tree. Meals with higher average energy content were lunch for Brazil, and dinner for the UK. The Brazilian main meal ( $58 \pm 0.13$ points) had a better nutritional quality than UK's main meal $(54 \pm$ 0.46 points), with more content of fiber and carbohydrate, and less total fat, saturated fat and energy density. However, UK's main meal included more fruits and vegetables. Food preparations with rice and beans were classified as Brazilian main meal, while fast food items, as fried potatoes, sandwiches and sugary beverages, were classified as UK main meals. A higher main meals quality in Brazil, was significantly positively associated with age, and negatively associated with gender, energy intake, nutritional status and family income, and in UK, only age was positively associated with MMQI. Although main meals in Brazil still have a higher nutritional quality compared to the UK, main meals consumed in both countries needs nutritional improvement.

Keywords: Meal, Main meal, Meal Quality, Meal score, Brazil, UK

\section{Introduction}


Overweight and obesity, once considered a problem only in high-income countries, are now on the rise in low- and middle-income countries (Monteiro, 2004). The 2008-2009 Brazilian Household Budget Survey and the Brazilian National Health Survey in 2013 found changes in the relative magnitude of malnutrition and overweight among Brazilians, showing a continuous weight increase in adolescents and adults over the last years (IBGE, 2010; IBGE 2014).

It is well known and generally accepted that the rise of overweight and obesity is the result of an obesogenic environment, coming from the industrial development. In this context, although, the economic growth is especially important for lower-income countries (allowing the change from poverty to economic prosperity), in middle-income countries the economic development and income increase may not necessarily result in better quality of life, since the population will have access to all types of food products (Egger \& Swinburn, 2010). Economic development generate technological and industrial changes, with transitions in the dietary patterns, making more cheap and caloric foods, rich in fat, sugar and salt, leading the population to an excessive energy intake (Swinburn et al, 2011).

Unlike Brazil, the dietary pattern of UK, as gauged by household expenditure surveys, includes many ready-to-consume products (Mourabac et al, 2013). Four different dietary patters have been reported to explain the food habit of low-income adults from de UK: (1) fast food, (2) health aware, (3) traditional, and (4) sweet. However, the "fast food" patterns appeared to explain the greatest proportion of the variance (Hamer \& Mishra, 2010). 
In Brazil, although Mourabac et al (2013) had shown that Brazilian diet is still composed mostly of fresh foods, culinary ingredients and homemade meals, the consumption of fruits and vegetables has decreased, whereas consumption of processed foods and ready-made meals, inside and away from home, has increased (Monteiro et al, 2010; Bigio et al, 2011; Gorgulho et al, 2013). Gorgulho et al (2013) observed that the characteristics of the meals consumed in São Paulo, a highly industrialized and urbanized megacity, regardless of the place of consumption, were not in line with national nutritional guidelines.

Due to the complexity of diet and the potential for interactions among dietary components, analysis of daily dietary patterns are being applied in nutritional epideiology, considering different foods and food groups consumed. However, whilst studying dietary patterns has served us to better understand food consumption, understanding each meal composition may help us to increase our ability to understand diet-disease patterns (Hearty and Gibney, 2008). Differences in a single meal could be sufficient to provoke benefits or damage to the health, considering that meal with distinct composition elicit different postprandial responses (Monfort-Pires \& Ferreira, 2016).

Cross-national comparison of meal quality had rarely been attempted, but assessment of diet quality between countries would be especially valuable. Clearly UK and Brazil are in different stages of nutritional transition (IBGE, 2010; Wang et al, 2011) and to compare their similarities and differences can provide insights in how to confront the current epidemiological reality. Based on the exposed, this study 
aim to compare the nutritional quality and composition of the main meal consumed by adults in Brazil and UK.

\section{Material and Methods}

The characterization of the meals, analysis of dietary quality and association with the nutritional status were carried out in two databases with representative samples, one conducted in UK and one conducted in Brazil.

\section{UK data}

UK's data was extracted from the National Diet and Nutrition Survey (NDNS) rolling programme, which is a cross-sectional household survey that objective gather data representative of the UK population on food consumption, nutrient intakes and nutritional status (UK, 2014). Briefly, this national survey is conducted on a rolling basis every year, since 2008, with the most recent available one being conducted in $2011 / 2012$. It aims to collect data of 1000 people per year (500 adults aged 19 years and older, excluded pregnant, as well as 500 children aged 1.5 to 18 years old), covering all the four countries of the UK: England, Wales, Scotland and Northern-Ireland. The sample was drawn from the Postcode Address File, clustered into Primary Sampling Units. Full details of the survey's methodology and procedures are described in the user guide published by the UK Food Standards Agency (UK, 2013). Information on demographics and general health, cooking skills and facilities, shopping and food preparation practices, eating habits, food avoidance and physical activity were collected during a computer assisted personal interview. 
For this specific study, data from 1441 individuals aged 19-59 years, who provided complete productive interviews and dietary data was used.

\section{Brazilian data}

Brazilian's data was extracted from the National Dietary Survey (INA), an individual food intake module of the 2008-2009 Brazilian Household Budget Survey (BHBS). This survey was conducted by the Brazilian Institute of Geography and Statistics and aims to measure consumption patterns, spent, income and assets of the families, including data on individual food consumption (IBGE, 2010). The individuals were interviewed about demographic and economic issues, nutritional status and food consumption. The BHBS 2008-2009 used a two-stage cluster sample, after the geographical and statistical stratification of the primary sample units based on the 2000 Brazilian Demographic Census. A subsample of $25 \%$ of households from the original 2008-2009 BHBS sample was randomly selected for investigating individual food consumption in INA. The detailed database and methodology has been described (Schiquieri, 2008). For this study, it was used data from 16730 adults (19-59 years), residents of urban area, who provided complete productive interviews (excluded pregnant).

\section{Dietary data collection}

In both studies, individuals were questioned at home by trained interviewers. Food consumption was measured by means of food records, two measures on nonconsecutive days, for respondents by BHBS, and four measures (two weekdays and two weekend), for the NDNS respondents, in which individuals reported all of 
the food and drink consumed on the days in question, the time, the quantities consumed according to portion sizes, cooking method as well as the source of the food. The quality control of dietary data collection was conducted by trained interviewers, who reviewed the information contained in the food records to detect errors in the completion and make the necessary corrections.

\section{Data analyses}

The criteria to define each meal were time slots of consumption defined by the participants (Meiselman, 2008), 6-10 am for breakfast, 11-15pm for lunch and 18-21pm for dinner; considering the eating episode with higher energy contribution in these time slot. After this, the main meal was defined as the meal with the highest contribution to overall energy and nutrients in each country.

The Main Meal Quality Index (MMQI), a previously developed index, was used to assess the nutritional quality of the meal (Gorgulho et al, 2016a). The MMQI is composed of ten components: fruits (in grams), vegetables (excluding potatoes, in grams), animal protein/total protein ratio, fiber (in grams), carbohydrate (\%),total fat $(\%)$,saturated fat $(\%)$,processed meats (in portions), sugary beverages and desserts (in portions), and energy density. Each component score ranged between zero and 10 points and the final score ranged between 0-100 points. Higher results obtained in the MMQI score represent better nutritional quality of the meal consumed. The MMQI as an instrument for the evaluation, monitoring and comparison of the nutritional quality of meals showed good internal validity and reliability for use in both populations (Gorgulho et al, 2016a; Gorgulho et al, 2016b). 
In order to describe the participants, nutritional status was defined using the calculation of the BMI according the World Health Organization (WHO) referential. The MMQI and its components were described and compared between Brazil and UK adults. The MMQI final score of main meal consumed in Brazil and UK were analyzed by linear regression models adjusted by gender (male or female), age (years), family income (pounds), BMI (normal weight, overweight or obesity) and energy content (kcal).

Differences in food groups consumed in the main meal in Brazil and UK were observed using the classification decision tree (rpart-algorithm, a variant of CART), one of the main supervised techniques of data mining. The decision tree construction required that foods reported in food records were grouped, resulting the attributes. To compose the 25 food groups (rice; other cereals; legumes; fruits; raw vegetables; cooked vegetables; fried potatoes; no fried potatoes; soups; pasta; sandwiches; snacks; pizza; breads; dessert; non-processed meats; fish and seafood; processed meat; eggs; dairy products; cheeses; alcoholic beverages; sugary beverages; coffee; tea), food habits of each country and nutritional characteristics of each food were considered.

The generation of the decision tree followed the top-down construction, considering the Gini Index and gain information for choice the attributes. The model pruning was based on the errors assigned to each branch of the tree, observing the trade-off accuracy of estimation and parsimony. A large decision tree can be grown to fit the data very well, leading to overfitting and to a reduced the capability to accurately fit new data. Thus, to improve the robustness of the final decision tree, the 
cost-complexity and cross-validation pruning can be applied. The current analysis considered the complexity parameter default value of 0.01 to the pre-pruning, and used the cross-validation method to estimate the performance of the decision tree model. For this approach, the entire data set was divided into two datasets, one for training $(2 / 3$ of the entire data) and one for validation ( $1 / 3$ of the entire data).

The decision tree was constructed applying the rpart-routine in $\mathrm{R}$ environment for statistical computing and graphics (The R Project, version 3.2.3), using the default values specified in rpart (minsplit=20; minbucket=minsplit/3; maxcompete $=4$; maxsurrogate $=5$; usesurrogate $=2$ ). Other analyses were performed using "survey" module of the statistical software Stata (Stata Corp., version 13, College Station) at the significance level of $5 \%$. The project was approved by the Research Ethics Committee of the School of Public Health, University of São Paulo.

\section{Results}

Considering the daily intake, the meals with the higher average energy content, defined as the main meal, were lunch, for Brazil, and dinner, for the UK. Characteristics of Brazil and UK populations were described in Table 1. The proportion of men was similar in both samples, around 44\%. The UK family income, in mean, was at least twice the Brazilian family income (by tertiles). Approximately $48 \%$ of Brazilians and $67 \%$ of Britons were overweight. 
Table 1. Subjects caracteristics. Brazil, 2008/09, and UK, 2008/09-2011/12.

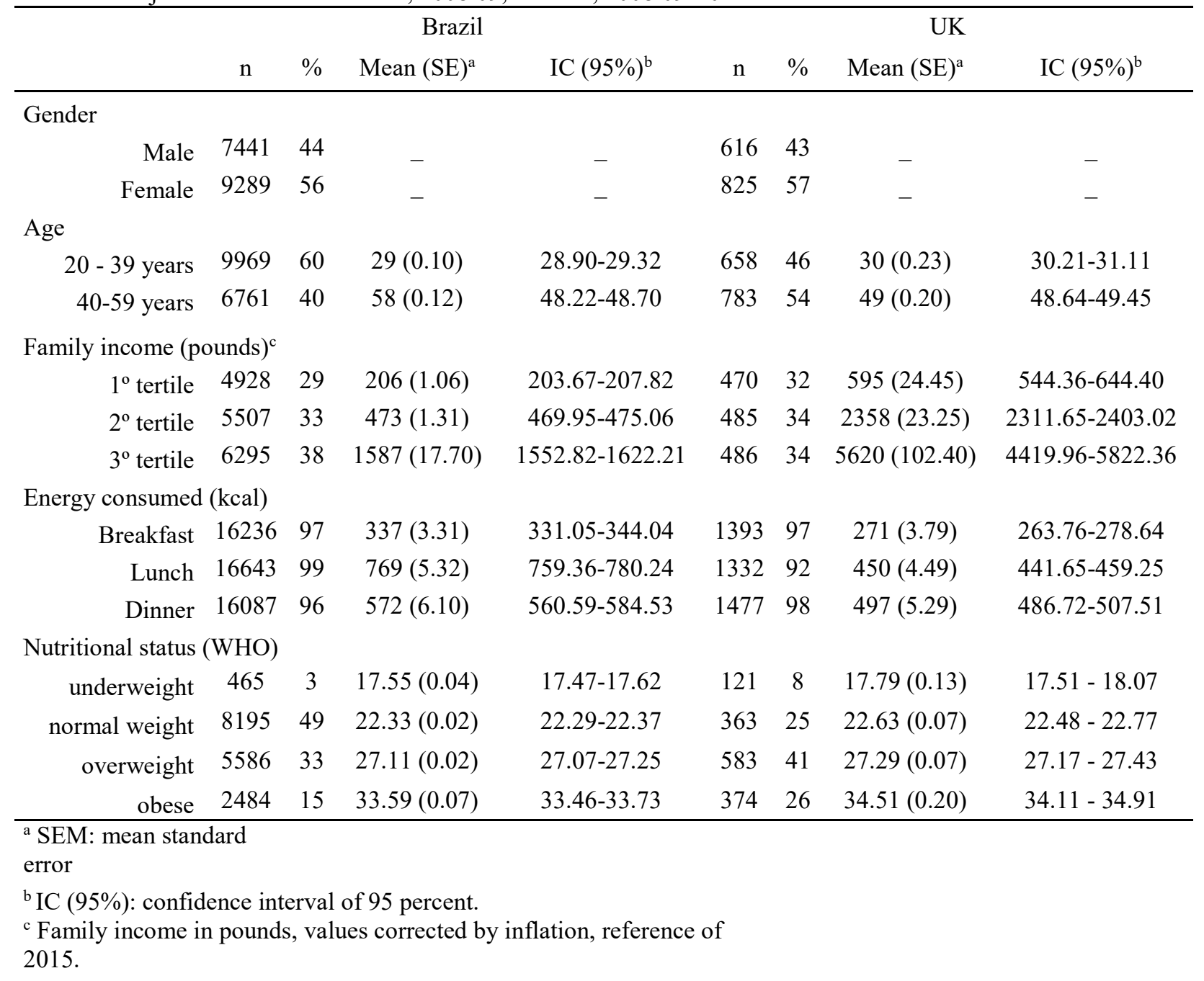

For Brazilian and UK's populations, the MMQI scores were normally distributed and the main meal quality comparison are presented in Table 2. The Brazilian main meal had a statistically significantly higher nutritional quality (58 points) than UK (54 points). 
Table 2. The MMQI and its components score. Brazil, 2008/09, and UK, 2008/09-2011/12.

\begin{tabular}{|c|c|c|c|c|c|c|c|c|c|c|}
\hline & \multicolumn{5}{|c|}{ Brazil } & \multicolumn{5}{|c|}{ UK } \\
\hline & $\begin{array}{l}\text { Mean } \\
(\text { SEM) }\end{array}$ & $\begin{array}{l}95 \% \text { Conf. } \\
\text { Interval }\end{array}$ & P25 & P50 & P75 & $\begin{array}{l}\text { Mean } \\
(\mathrm{SEM})\end{array}$ & $\begin{array}{l}95 \% \text { Conf. } \\
\text { Interval }\end{array}$ & P25 & P50 & P75 \\
\hline Fruit* & $\begin{array}{c}0.84 \\
(0.02)\end{array}$ & $0.80-0.88$ & 0.00 & 0.00 & 0.00 & $\begin{array}{l}1.22 \\
(0.07)\end{array}$ & $1.08-1.36$ & 0.00 & 0.00 & 0.47 \\
\hline $\begin{array}{l}\text { Vegetable (excluded } \\
\text { potato)* }\end{array}$ & $\begin{array}{c}0.79 \\
(0.02)\end{array}$ & $0.76-0.83$ & 0.00 & 0.00 & 0.00 & $\begin{array}{l}3.09 \\
(0.11)\end{array}$ & $2.88-3.30$ & 0.00 & 0.00 & 7.35 \\
\hline $\begin{array}{l}\text { Animal protein/total } \\
\text { protein* }\end{array}$ & $\begin{array}{l}7.28 \\
(0.3)\end{array}$ & $7.21-7.35$ & 0.00 & 10.00 & 10.00 & $\begin{array}{l}9.05 \\
(0.06)\end{array}$ & $8.94-9.16$ & 9.89 & 10.00 & 10.00 \\
\hline Fiber* & $\begin{array}{c}5.13 \\
(0.04)\end{array}$ & $5.07-5.20$ & 0.00 & 5.36 & 10.00 & $\begin{array}{c}4.09 \\
(0.12)\end{array}$ & $3.86-4.33$ & 0.00 & 0.00 & 10.00 \\
\hline Carbohydrate* & $\begin{array}{c}5.15 \\
(0.03)\end{array}$ & $5.09-5.21$ & 0.00 & 5.37 & 10.00 & $\begin{array}{l}3.96 \\
(0.11)\end{array}$ & $3.75-4.17$ & 0.00 & 2.46 & 8.57 \\
\hline Total fat* & $\begin{array}{c}7.89 \\
(0.03)\end{array}$ & $7.75-7.85$ & 6.44 & 10.00 & 10.00 & $\begin{array}{c}5.27 \\
(0.11)\end{array}$ & $5.04-5.50$ & 0.00 & 5.86 & 10.00 \\
\hline Satured fat* & $\begin{array}{c}8.02 \\
(0.03)\end{array}$ & $7.97-8.08$ & 7.98 & 10.00 & 10.00 & $\begin{array}{c}5.36 \\
(0.12)\end{array}$ & $5.12-5.60$ & 0.00 & 6.69 & 10.00 \\
\hline Processed meat* & $\begin{array}{c}9.62 \\
(0.13)\end{array}$ & $9.60-9.65$ & 10.00 & 10.00 & 10.00 & $\begin{array}{c}9.48 \\
(0.03)\end{array}$ & $9.41-9.55$ & 10.00 & 10.00 & 10.00 \\
\hline $\begin{array}{l}\text { Sugary beverages } \\
\text { and desserts }\end{array}$ & $\begin{array}{c}8.57 \\
(0.02)\end{array}$ & $8.52-8.61$ & 10.00 & 10.00 & 10.00 & $\begin{array}{c}8.52 \\
(0.07)\end{array}$ & $8.37-8.66$ & 8.95 & 10.00 & 10.00 \\
\hline Energy density* & $\begin{array}{c}4.88 \\
(0.03)\end{array}$ & $4.82-4.94$ & 0.00 & 4.97 & 9.15 & $\begin{array}{c}4.34 \\
(0.11)\end{array}$ & $4.12-4.57$ & 0.00 & 2.73 & 10.00 \\
\hline Final score* & $\begin{array}{l}58.11 \\
(0.13)\end{array}$ & $57.85-58.37$ & 47.25 & 60.00 & 70.68 & $\begin{array}{l}54.40 \\
(0.46)\end{array}$ & $53.50-55.31$ & 40.19 & 53.13 & 67.25 \\
\hline
\end{tabular}

*significant differences in bivariate linear regress model $(\mathrm{p}<0.001)$

Table 3 shows the associations between MMQI score and all variables analysed. Brazil had a main meal quality better than UK, independent of gender, age, income, nutritional status and energy intake. For the main meal consumed in Brazil, the MMQI scores were significantly positively associated with gender and age, and negatively associated with family income, nutritional status and energy intake, using either bivariate and adjusted models. Even though, for UK, age and family income were positively associated with the MMQI score in bivariate models, while just age remained associated with the final score (positively) in the adjusted model. 
Table 3. Main meal quality and associated factors. Brazil, 2008/09, and UK, 2008/09-2011/12.

\begin{tabular}{|c|c|c|c|c|c|c|c|c|c|c|}
\hline & \multicolumn{5}{|c|}{ Bivariate Models } & \multicolumn{5}{|c|}{ Adjusted Model* } \\
\hline & $\beta$ & \multicolumn{2}{|c|}{$95 \% \mathrm{CI}$} & $\mathrm{p}$ & $\begin{array}{c}\mathrm{p} \\
\text { trend }\end{array}$ & $\beta$ & \multicolumn{2}{|c|}{$95 \% \mathrm{CI}$} & $\mathrm{p}$ & $\begin{array}{c}\mathrm{p} \\
\text { trend }\end{array}$ \\
\hline \multicolumn{11}{|l|}{ Comparing Brazil and UK } \\
\hline UK (reference Brazil) & -3.71 & -4.63 & -2.79 & $<0.001$ & & -4.42 & -5.36 & -8.85 & $<0.001$ & \\
\hline \multicolumn{11}{|l|}{ Brazil } \\
\hline Gender (reference female) & 2.55 & 2.03 & 3.08 & $<0.001$ & & 3.22 & 2.67 & 3.77 & $<0.001$ & \\
\hline Age (years) & 0.09 & 0.06 & 0.11 & $<0.001$ & & 0.09 & 0.07 & 0.12 & $<0.001$ & \\
\hline Family income (pounds) & -0.01 & -0.01 & -0.01 & $<0.001$ & & -0.01 & -0.01 & 0.01 & $<0.001$ & \\
\hline \multicolumn{5}{|c|}{ Nutritional status (reference normal weight) } & 0.29 & & & & & 0.05 \\
\hline Overweight & 0.07 & -0.51 & 0.65 & 0.82 & & -0.49 & -1.07 & 0.10 & 0.11 & \\
\hline Obesity & -0.56 & -1.33 & 0.21 & 0.16 & & -0.90 & -1.67 & $0.12^{-}$ & 0.02 & \\
\hline Energy consumed (kcal) & -0.01 & -0.01 & -0.01 & $<0.001$ & & -0.01 & -0.01 & $0.01^{-}$ & $<0.001$ & \\
\hline \multicolumn{11}{|l|}{ UK } \\
\hline Gender (reference female) & 0.08 & -1.74 & 1.91 & 0.93 & & 0.06 & 0.96 & $\begin{array}{r}- \\
1.86\end{array}$ & 1.97 & \\
\hline Age (years) & 0.15 & 0.07 & 0.23 & $<0.001$ & & 0.16 & 0.08 & 0.24 & $<0.001$ & \\
\hline Family income (pounds) & 0.01 & 0.01 & 0.01 & 0.05 & & 0.00 & 0.14 & 0.00 & 0.138 & \\
\hline \multicolumn{5}{|c|}{ Nutritional status (reference normal weight) } & 0.72 & & & & & 0.29 \\
\hline Overweight & -0.80 & -2.90 & 1.31 & 0.46 & & -1.52 & 0.17 & 3.67 & 0.63 & \\
\hline Obesity & -0.77 & -3.14 & 1.60 & 0.52 & & -1.66 & 0.18 & 4.08 & 0.76 & \\
\hline Energy consumed (kcal) & 0.01 & -0.01 & 0.01 & 0.84 & & 0.01 & -0.01 & 0.03 & 0.928 & \\
\hline
\end{tabular}

*Adjusted by all variables with bivariate model 
Figure 1. Decision tree classification of main meal composition in Brazil and UK. Brazil, 2008/09, and UK, 2008/09-2011/12.

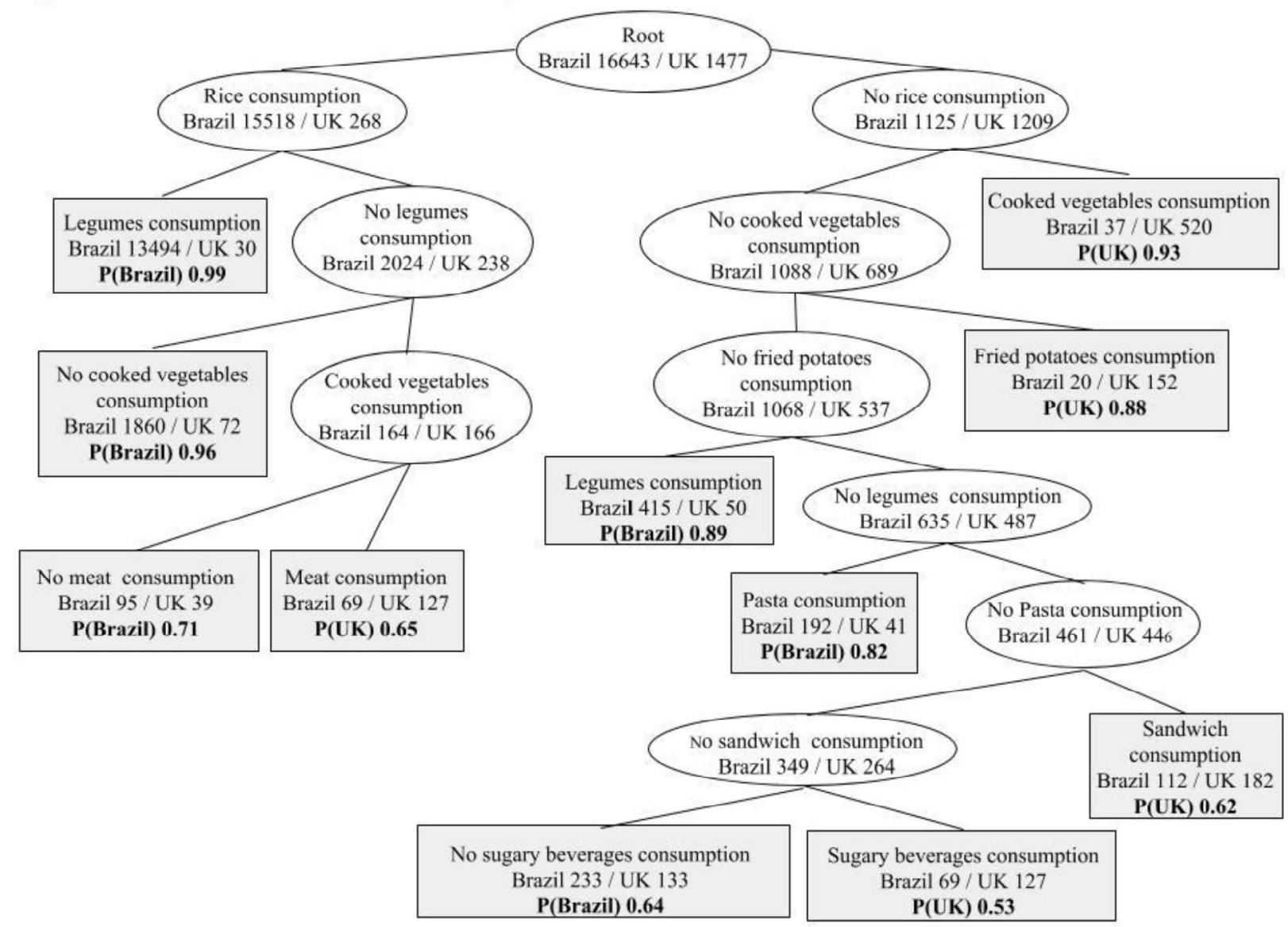

Differences in main meal composition in Brazil and UK could be observed in figure 1. Decision attributes, the tree nodes, are represented by ellipses and classification attributes, the leaves of the tree, are represented by rectangles. The order of nodes in the tree was determined by the ability to distinguish the two populations, starting with the most heterogeneous division; missing values were not observed in primary splits. Nodes that, per pruned leaf, produce a smaller increase in the error rate $(\alpha<0.05)$ and did not reduce the accuracy of the tree were pruned. The classifier recognition rate (accuracy) between training and validation data was $96 \%$. 
The node shows the number of individuals from each country that were classified by the attribute, and at the leafs is possible to observe the probability of each country be classified $(\mathrm{P}($ Brazil $)+\mathrm{P}(\mathrm{UK})=1)$.

Food group combinations classified as characteristic of Brazilian main meals content were: rice and legumes $(p=0.99)$; rice $(p=0.96)$; rice and cooked vegetables $(p=0.71)$; legumes $(p=0.89)$; and pasta $(p=0.82)$; while the food groups classified as characteristics of UK main meal were: rice, cooked vegetables and non-processed meats $(p=0.65)$; cooked vegetables $(p=0.93)$; fried potatoes $(p=0.88)$; sandwich $p=$ (0.62); and sugary beverages $(\mathrm{p}=0.53)$.

\section{Discussion}

This study examined similarities and differences between main meals consumed in countries in different stages of development and nutritional transition and found that Brazil and UK have meals with different profiles (Meinselman, 2008). In Brazil, the meal by predefined time slot with the higher energy and nutrients contents over the day was the lunch, while in UK this was dinner. The 1946 British birth cohort observed the trend to reduction the proportion of energy and macronutrients consumed at lunch in the last years, which was compensated by a higher intake in the evening (Almoosawi et al, 2012).

The Brazilian main meal had a better nutritional quality than UK main meal, with more contributions of fiber and carbohydrate, and less total fat, saturated fat and energy density. The British Nutrition Foundation has shown that popular meals consumed in UK, homemade or not, often exceed recommendations for saturated fat 
(Benelam \& Stannler, 2015). However, the UKs main meal included more fruits and vegetables. In Sao Paulo (biggest city in Brazil), the daily intake of fruit and vegetables was below the recommendation ( $400 \mathrm{~g} /$ day), to over $90 \%$ of the population not adhering to the dietary recommendations (Bigio et al, 2011).

Comparing the main meal composition between the two countries we observed that culinary ingredients, like rice and beans, were classified as a Brazilian main meal, while fast food items, as fried potatoes, sandwiches and sugary beverages, were classified as UK main meal. Despite of the increasing participation of ready-to-eat food products in daily intake, it is observed that most Brazilians, in contrast of British, still prepare their own meals (Mourabac et al, 2013).

Santos et al (2015) described five lunch patterns consumed in Sao Paulo: (1) "Traditional", characterized by rice and beans, by inverse correlations with pasta, explain $8.5 \%$ of the variance; (2) "Salad", characterized by natural juices and vegetables, explain $7.5 \%$ of the variance; (3) "Sweetened Juice", characterized by natural juices and sugar, explain $6.5 \%$ of the variance; (4) "Western", characterized by soft drinks, alcoholic beverages, processed meats, pasta and sugar, explain $6.0 \%$ of the variance; and (5) "Meats", characterized by eggs, poultry meat and fish, by inverse correlations with beef, explain $5.5 \%$ of the variance. The "traditional" pattern described by Santos et al, that explain the greatest proportion of the variance, is similar to the Brazilian main meal classification found in our study.

During 2008, 2.6\% and 10.7\% of total energy consumed in Brazil and UK, respectively, came from ready-to-consume meals (Mourabac etal, 2013). In the same 
year, the food groups that contributed with at least $5 \%$ of total energy consumed in Brazil were: grains (16\%); oils (11\%); table sugar (11\%); meats and poultry $(9 \%)$; and beans $(5 \%)$ (IBGE,2010) while in UK were: ready-to-consume meals $(11 \%)$; breads (10\%); candies, chocolates and ice creams (10\%); milk and plain yogurt $(7 \%)$; and meats and poultry (5\%) (Whitton et al, 2011). The contribution of fruits was similar in both countries, $2.3 \%$ in Brazil and $2.5 \%$ in UK, however the vegetables contribution in the UK (1.3\%) was approximately twice than in Brazil $(0.7 \%)$ (Mourabac etal, 2013).

For both countries, as described in literature and observed in this study, older adults have better dietary habits (Gorgulho et al, 2013). However, in Brazil, similar to observed in 2013 Brazilian Health Survey (Jaime et al, 2015), women appear to have the least favorable main meal quality; characterized by a low consumption of rice and beans, with a higher consumption of sugary foods.

While in Brazil and UK higher income is associated with higher consumption of fruits and vegetables (Maguire \& Monsivais, 2015), in Brazil higher income is also associated with higher frequency acquisition of processed meats, soft drinks and ready-to-eat meals (Levy et al, 2009). In developing countries individuals with higher incomes not necessarily have healthier diets (Egger \& Swinburn, 2010). Globalization and food industry development increase the availability of higher energy density foods, and it is known that the income increase facilitates the access to new foods, which can lead to over-consumption of food and drink sources of sugar, sodium and fat (Lock et al, 2010). 
There is no consensus in the literature regarding the best way to define a meal, either by self-report, time or by contribution of energy or nutrients. Murakami et al (2015), examining how different definitions used to classify meals can affect associations between dietary intake and adiposity measures, observed that, depending of the meal definition used, meal frequency can be, or not, associated with BMI and waist circumference. In this study was applied the time slot definition, considering the higher energy content in the period, and was observed significant correlation between meal quality and nutritional status just in Brazil.

The study was limited that measures of physical activity were not available, and, in addition, databases used came from observational studies, which were not designed for causality analyses. Furthermore, the prevalence of overweight in UK is approximately $70 \%$.

Strenghts of the study include that the MMQI was developed based on international recommendations and previously tested, presenting acceptable values of internal validity and reliability for both populations, which allowed adequate evaluation and comparison of the populations.

\section{Conclusion}

Studying meal patterns can help to understand how dietary intake could be improved, educating populations in a clear and simple way. Despite of the increase consumption of ready-to-eat food products, it was observed that Brazilians still have the habit of consuming traditional foods, like as rice and beans. However, although 
Brazil has a main meal with better nutritional quality than UK, main meals of both countries needs nutritional improvement.

\section{Reference}

1. Almoosawi, S., Winter, J., Prynne, C. J., Hardy, R., \& Stephen, A. M. (2012). Daily profiles of energy and nutrient intakes: are eating profiles changing over time\&quest. European journal of clinical nutrition, 66(6), 678-686.

2. Benelam, B., \& S. Stanner (2015). "Development of a methodology to assess the nutrient profile of popular UK meals." Nutrition Bulletin 40(4): 315-325.

3. Bigio, RS; Verly-Jr, E.; Castro, MA de; César, CLG; Fisberg, RM; \& Marchioni, DML (2011). Determinantes do consumo de frutas e hortaliças em adolescentes por regressão quantílica. Rev Saúde Pública. 45: 448-456.

4. IBGE - Brazilian Institute of Statistics and Geography (2010). Pesquisa de orçamentos familiares 2008_2009: Avaliação nutricional da disponibilidade de alimentos no Brasil [Household food budget survey 2008_2009: Nutritional assessment of food availability in Brazil].

5. IBGE - Brazilian Institute of Statistics and Geography (2014). Pesquisa Nacional de Saúde 2013: Percepção do Estado de Saúde, estilos de vida e doenças crônicas [National Health Survey 2013: Perceived health status, lifestyles and chronic diseases in Brazil].

6. Claro, R. M., Carmo, H. C. E. D., Machado, F. M. S., \& Monteiro, C. A. (2007). Income, food prices, and participation of fruit and vegetables in the diet. Revista de Saúde Pública, 41(4), 557-564. 
7. de Oliveira Santos, R., Fisberg, R. M., Marchioni, D. M., \& Baltar, V. T. (2015). Dietary patterns for meals of Brazilian adults. British Journal of Nutrition, 114(05), 822-828.

8. Egger G \& Swinburn B (2010). Planet obesity: how we're eating ourselves and the planet to death. Sydney: Allen and Unwin.

9. Garcia RWD (2003). Reflexos da globalização na cultura alimentar: considerações sobre mudanças na alimentação urbana. Rev Nutr. 16(4): 48392.

10. Gorgulho BM, Fisberg RM \& Marchioni DML. Nutritional quality of major meals consumed away from home in Brazil and its association with the overall diet quality. Prev Med. 57:98-101.

11. Gorgulho BP, Gerda K. Sarti, FM, et al (2016a). Measuring quality of meals in different cultural and socioeconomic context: development and validation of a index. In press.

12. Gorgulho BP, Gerda K. Sarti, FM, et al (2016b). Evaluation of the Main Meal Quality Index for use in UK. In Press.

13. Guenther PM, Reedy J, Krebs-Smith SM \& Reeve BB (2008). Evaluation of the Healthy Eating Index-2005. Journal of the American Dietetic Association. 108(11):1854-1864.

14. Hamer M \& Mishra GD (2010). Dietary patterns and cardiovascular risk markers in the UK low income diet and nutrition survey. Nutr, Metb and Card Diseases. 20:491-497. 
15. Hearty AP \& Gibney MJ (2008). Analysis of meal patterns with the use of supervised data mining techniques - artificial neural networks and decision trees. Am J Clin Nutr. 88: 1632-42.

16. IOM - Institute of Medicine (2006). Food marketing to children and youth: Threat or opportunity? Washington.

17. Jaime PC, Stopa SR, Oliveira TP, et al (2015). Prevalência e distribuição sociodemográfica de marcadores de alimentação saudável, Pesquisa Nacional de Saúde, Brasil 2013. Epidemiologia e Serviços de Saúde, 24(2), 267-276.

18. Levy, R. B., Claro, R. M., Mondini, L., Sichieri, R., \& Monteiro, C. A. (2012). Regional and socioeconomic distribution of household food availability in Brazil, in 2008-2009. Revista de Saúde Pública, 46(1), 06-15.

19. Lock, K., Smith, R. D., Dangour, A. D., Keogh-Brown, M., Pigatto, G., Hawkes, C., \& Chalabi, Z. (2010). Health, agricultural, and economic effects of adoption of healthy diet recommendations. The Lancet, 376(9753), 16991709.

20. Maguire, Eva R., \& Pablo Monsivais (2015). "Socio-economic dietary inequalities in UK adults: an updated picture of key food groups and nutrients from national surveillance data." British Journal of Nutrition 113.01: 181189.

21. Meiselman HL (2008). Dimensions of the meal Journal of foodservice. 19:1321.

22. Monfort-Pires, M., \& Ferreira, S. R. G. (2016). Modification in a single meal is sufficient to provoke benefits in inflammatory responses of individuals at 
low-to-moderate cardiometabolic risk. Clinical Nutrition. Doi:10.1016/2016.02.015.

23. Monteiro, C. A., Moura, E. C., Conde, W. L., \& Popkin, B. M. (2004). Socioeconomic status and obesity in adult populations of developing countries: a review. Bulletin of the World Health Organization, 82(12), 940946.

24. Monteiro CA, Levy RB, Claro RM, de Castro RR \& Cannon G (2010). Increasing consumption of ultra-processed foods and likely impact on human health: evidence from Brazil. Pub Health Nutr. 14(1):5-13.

25. Moubarac JC, Claro RM, Baraldi LG, Levy RB, Martins APB, Cannon G \& Monteiro CA (2013). International differences in cost and consumption of ready-to-consume food and drink products: United Kingdom and Brazil, 2008-2009. Global Public Health. DOI:10.1080/17441692.2013.796401.

26. Murakami, Kentaro, \& M. Barbara E. Livingstone (2015). Associations between meal and snack frequency and diet quality and adiposity measures in British adults: findings from the National Diet and Nutrition Survey. Public health nutrition 19(9):1624-1634.

27. Popkin BM, Adair LS \& Ng SW (2011). Global nutrition transition and the pandemic of obesity in developing countries. Nutrition Reviews. 70(1):3-21.

28. Popkin, Barry M., Linda S. Adair, \& Shu Wen Ng (2012). Global nutrition transition and the pandemic of obesity in developing countries. Nutrition reviews $70(1): 3-21$. 
29. UK, Public Health England. National Diet and Nutrition Survey Rolling Programme. User Guide for UK Core Sample Data. Food Standards Agency. UK Data Archive SN 6533; 2013.

30. UK, Public Health England. National Diet and Nutrition Survey: results from Years 1 to 4 (combined) of the rolling programme for 2008 and 2009 to 2011 and 2012. UK Data Archive; 2014.

31. Sichieri, R., Pereira, R. A., Martins, A., Vasconcellos, ABPA., \& Trichopoulou, A. (2008). Rationale, design, and analysis of combined Brazilian household budget survey and food intake individual data. BMC public health, $8(1), 89-93$

32. Swinburn BA, Sacks G, Hall KD, McPerson K, Finegood DT, Moodie ML, \& Gortmaker SL (2011). The global obesity pandemic: shaped by global drivers and local environments. Lancet. 378:804-814.

33. Thompson, F. E., Kirkpatrick, S. I., Subar, A. F., Reedy, J., Schap, T. E., Wilson, M. M., \& Krebs-Smith, S. M. (2015). The National Cancer Institute's Dietary Assessment Primer: A Resource for Diet Research. Journal of the Academy of Nutrition and Dietetics, 115(12), 1986-1995.

34. Wang YC, McPerson K, Marsh T, Gortmaker SL \& Brown M (2011). Health and economic burden of the projected obesity trends in the USA and the UK. Lancet. 378:815-825.

35. Whitton C, Nicholson SK, Roberts C, Prynne CJ, Pot G, Olson A, Fitt E, Cole D, Teucher B, Bates B, Henderson H, Pigott S, Deverill C, Swan G \& Stephen AM (2011). National Diet and Nutrition Survey: UK food consumption and nutrient intakes from the first year of the rolling programme 
and comparisons with previous surveys. British Journal of Nutrition; 106(12): 1899-1914.

36. WHO - World Health Organization (2003). Diet, nutrition and the prevention of chronic diseases. Report of a joint WHO/FAO expert consultation. WHO Technical Report Series no. 916.

37. WCRF/AICR - World Cancer Research Fund/American Institute for Cancer Research (2007). Food, nutrition, physical activity, and the prevention of cancer: A global perspective. Washington, DC.

\subsubsection{MANUSCRITO 4}

Meal quality and sociodemographic conditions in the Brazilian population

Bartira Gorgulho; Roberta Santos; Juliana Teixeira; Valéria Baltar; Dirce M L Marchioni

Abstract

Objective. This study aimed to assess the lunch quality consumed by adults in Brazil and its relationship with sociodemographic factors. Design. A cross-sectional study representative of Brazilian populations. Subjects. Individual food consumption data (food intake record) of 16096 adults from the National Dietary Survey/Brazilian Household Expenditures Survey. Setting. The lunch quality was evaluated applying a previously developed index, the Main Meal Quality Index (MMQI), composed by 10 items of equal weights that results in a score range of $0-100$ points. The association between lunch quality and sociodemographic factors was measured by linear regression models. Results. The average energy consumption at lunch was 704 $\mathrm{kcal}(\mathrm{SD}=300)$, and the mean of the meal quality score was 57 points $(\mathrm{SE}=0.30)$. 
North region had the worst MMQI adjusted score (56 points, $\mathrm{SE}=0.07$ ), while Midwest had the best MMQI adjusted score (59 points, $\mathrm{SE}=0.05$ ). The MMQI final score was negatively associated with be male, have between 20-39 years, have eight years or more of education, have a per capita income of at least three minimum wage, and with the consumption of meals prepared away from home. Conclusions. Despite differences among sociodemographic factors, all regions had a moderate consumption of foods rich in sugars and fats, and insufficient consumption of fruits and vegetables.

Keywords: Lunch. Eating habits. Meal Quality. Sociodemographic factors.

\section{Introduction}

The relationship between food consumption and health is unquestionable. Traditionally, most studies have focused on daily dietary intake and its effects. However, a recent systematic review highlighted the insufficiency of studies that assess combinations of food at meal level ${ }^{(1)}$. The choice of foods that are consumed in the same meal occurs in a very complex way, being modulated by several determinants, such as sociodemographic conditions, gender, age, nutritional status, place of consumption, food preparation, and cultural habits ${ }^{(2-4)}$. Observing the food combination in each meal allows a better understanding of the complexity of the $\operatorname{diet}^{(5,6)}$, emphasizing peculiarities that would not be found in global analyses ${ }^{(7)}$. The results depict the current food habits of a specific population, consisting in a possible easy-to-understand field not only to the patient, but also to the not dietitian health professional. Monfort-Pires and Ferreira showed that changes in the composition of a 
single meal are enough to change the postprandial and inflammatory response in individuals $^{(8)}$.

Moreover, the meal quality have being associated with its place of preparation and consumption. Bandoni et al found that, when compared to meals eaten at home, meals consumed in commercial restaurants presented a higher contribution of sugar and fat ${ }^{(9)}$. In fact, Gorgulho et al (2013), evaluating the nutritional quality of main meals consumed by residents of Sao Paulo, the biggest Brazilian city, found that main meals consumed by adolescents, adults and elderly were not nutritionally adequate, especially when they were consumed away from home ${ }^{(10)}$. A main meal contributes with the higher content of the energy necessity and with at least $30 \%$ of the daily nutrient intake.

Brazil is a country with continental dimensions and a great diversity ${ }^{(11)}$. There are important sociodemographic and economic disparities among the five macro-regions, being associated with different food habits, incidences of diseases and mortality patterns. The poorer the educational level, the higher the prevalence of chronic diseases ${ }^{(12)}$. In this way, the geographic regions print their food identity. For example, the North region consuming more manioc flour, açaí and fresh fish; in the Northeast more eggs and crackers; in the Midwest more rice, beans, beef and milk; in the Southeast and South more salt bread, pasta, potatoes, cheese, yogurt and soft drinks ${ }^{(13)}$.

Thus, considering differences in sociodemographic characteristics and food habits between North, Northeast, South, Southeast and Midwest of Brazil, this study 
aims to evaluate the quality of lunch consumed by Brazilian adults and its association with demographic and socioeconomic variables in each Brazilian region. Thereby have a synthesis measurement of the lunch, the Brazilian main meal, may be helpful to support the standardization of nutritional guidelines for Populations.

\section{Methods}

This study used individual food consumption data from the National Dietary Survey (INA), composed by the personal food consumption block (questionnaire P07) of the Brazilian Household Budget Survey (HBS) conducted in 2008 and 2009 by the Brazilian Institute of Geography and Statistics (IBGE) ${ }^{(13)}$.

A sampling of HBS 2008/09, representative of Brazil, was carried out by conglomerates in two stages, the census tracts, the primary sampling units selected by simple random sampling, and the permanent households, the secondary sampling units selected by simple random sampling without replacement within each census tract.

The size of the complete sample of HBS 2008/09 was 4,696 census tracts, with 59,548 selected households, yet only 13,569 households were randomly selected to be interviewed regarding personal food consumption. This particular study used only data from individual food consumption relative to adults (20-59 years) residing in urban areas, excluded pregnant women, a starting sample composed by 16,638 individuals of both gender. 
Food consumption in INA was measured through self-reporting in two intake records on nonconsecutive days. Participants were instructed on how to annotate household measures, in addition to fill out the times and locations of meals (at home or away from home), and a detailed description of all foods and beverages consumed; including the method of preparation, ingredients and brands.

Quality control in the dietary data collection was performed by trained interviewers, who reviewed the information contained in food records in order to detect faults in annotations and made the necessary corrections. Items commonly omitted, such as candies and sweets in general, as well as beverages such as coffee and soda, had their consumption investigated by the interviewer.

For this study, lunch was defined as the food event that occurred between 11:00am and 3:00pm. When there was more than one food consumption episode reported within this time interval, the one with the highest energy contribution was considered, and the smaller values were disregarded. In order to consider the place of meal consumption in the analysis, only the data of the first food record were considered in this study. In this way, the final sample consisted of 16,096 adults who had at least one food consumption episode during this time slot.

To evaluate the quality of lunch, the Main Meal Quality Index (MMQI) was applied ${ }^{(14)}$. The MMQI consists of 10 items, of equal weight, which together result in a score between zero to 100 points: fruits; vegetables (except potatoes); carbohydrates; total fat; saturated fat; animal protein / total protein; fibers; processed meats; desserts and sugary drinks; and energy density (Table 1). The higher the score 
indicator, the better the quality of the meal ${ }^{(14)}$. The MMQI was based on international standards references and guidelines, and its internal validity and reliability were evaluated previously in two distinguished population: Sao Paulo ${ }^{(14)}$ and United Kingdom ${ }^{(15)}$. However, considering differences in cultural habits between Brazilian regions, the MMQI was once again tested for use in the INA, showing good reliability and internal validity, in similarity of Sao Paulo sample (supplementary material).

Table 1. MMQI components and score criteria.

\begin{tabular}{cccc}
\hline & & \multicolumn{2}{c}{ Score range } \\
Component & Recomendation ${ }^{\text {a }}$ & 0 point & 10 point \\
\hline Fruit & $400 \mathrm{~g}$ of fruits and vegetables per day & $\leq 0 \mathrm{~g}$ & $\geq 80 \mathrm{~g}$ \\
Vegetables (excluded potato) & $400 \mathrm{~g}$ of fruits and vegetables per day & $\leq 80 \mathrm{~g}$ & $\geq 160 \mathrm{~g}$ \\
Animal protein/total protein & 1 portion/day of vegetable protein & $100 \%$ & $\leq 80 \%$ \\
Fiber & $25 \mathrm{~g}$ per day & $\leq 7 \mathrm{~g}$ & $\geq 10 \mathrm{~g}$ \\
Carbohydrate & $55-75 \%$ of total energy & $\leq 40 \%$ & $\geq 55 \%$ \\
Total fat & $15-30 \%$ of total energy & $\geq 40 \%$ & $\leq 30 \%$ \\
Satured fat & $<10 \%$ of total energy & $\geq 13 \%$ & $\leq 10 \%$ \\
Processed meat & Avoid & $\geq 1 \mathrm{portion}$ & $0 \mathrm{portion}$ \\
Sugary beverages and & Avoid & $\geq 1 \mathrm{portion}$ & 0 portion \\
desserts & $\leq 1.25 \mathrm{kca} / \mathrm{g}$ & $\geq 1.65 \mathrm{kcal} / \mathrm{g}$ & $\leq 1.25 \mathrm{kcal} / \mathrm{g}$ \\
\hline Energy density & & &
\end{tabular}

a World Health Organization, 2003; World Cancer Research Fund, 2007

The MMQI is composed by 10 components of equal weights, which together result in a score between zero to 100 points. The higher the score indicator, the better the quality of the meal.

The demographic variables analyzed were gender (male and female) and age group (20-39 years and 40-59 years). Socioeconomic variables analyzed were education (up to 2 years, 3-8 years and more than 8 years of schooling completed) and income (up to 1 minimum wage per capita, 2 or more minimum wages per 
capita). In addition, it was considered the place of meal preparation (at home or away from home) and the energy value of the meal (in kcal) as adjustment variables.

Statistical analysis was performed using Stata, Version 13. The quality of lunch was described by measures of central tendency and dispersion of the final scores and of each item. The subsequent adjustment of association estimates employed linear regression models by Brazilian regions (North, Northeast, South, Southeast and Midwest). The selection of explanatory variables for multiple models was based on plausibility and statistical adjustment. A 5\% significance level was adopted.

\section{Results}

Regarding the population studied, 52\% were female, 60\% aged between 19 and 39 years, $55 \%$ studied eight completed years or more, $35 \%$ had per capita income of up to 1 minimum wage and $25 \%$ reported having lunch away from home in the first record. In general, the quality of the Brazilians lunch was higher to men, older, with low education (3 years or less and 3-8 years) in comparison with high education (8 years or more), those with lower per capita income ( 1 or less minimum wage and $1-2$ minimum wage) in relation to 3 or more minimum wage, that had home as the place of meal preparation, and lunch with energy content between 640 to $880 \mathrm{kcal}$ (Table 2). 
Table 2. Characteristics of population studied and the meal quality. Brazil, 2008-2009.

\begin{tabular}{|c|c|c|c|c|c|c|c|}
\hline \multirow[b]{2}{*}{ Variables } & \multicolumn{2}{|c|}{ Individuals } & \multicolumn{5}{|c|}{ Meal quality } \\
\hline & $\mathrm{n}$ & $\% *$ & Median & Mean & SE & IC 95 & \\
\hline \multicolumn{8}{|l|}{ Demographic } \\
\hline \multicolumn{8}{|l|}{ Gender } \\
\hline Male & 7098 & 47.8 & 61.03 & 58.41 & 0.41 & 58.5 & 59.3 \\
\hline female & 8998 & 52.2 & 58.79 & 56.73 & 0.35 & 56.37 & 57.08 \\
\hline \multicolumn{8}{|l|}{ Age } \\
\hline $19-39$ years & 99905 & 60.48 & 59.81 & 57.23 & 0.35 & 56.89 & 57.56 \\
\hline $40-59$ years & 6101 & 39.52 & 60.22 & 58.45 & 0.43 & 58.01 & 58.88 \\
\hline \multicolumn{8}{|l|}{ Socioeconomic } \\
\hline \multicolumn{8}{|l|}{ Education } \\
\hline 3 or less years & 1812 & 8.6 & 60.84 & 58.85 & 0.38 & 58.09 & 59.6 \\
\hline $3-8$ years & 5940 & 36.69 & 60.57 & 58.53 & 0.22 & 58.1 & 58.96 \\
\hline 8 or more years & 8344 & 54.7 & 58.85 & 56.84 & 0.19 & 56.46 & 57.21 \\
\hline \multicolumn{8}{|l|}{ Per capita Income } \\
\hline 1 or less minimum wage & 6994 & 34.86 & 60.07 & 58.2 & 0.2 & 57.81 & 58.59 \\
\hline $1-2$ minimum wage & 4489 & 29.2 & 60 & 57.8 & 0.25 & 57.31 & 58.3 \\
\hline 3 or more minimum wage & 4613 & 35.94 & 58.76 & 56.79 & 0.26 & 56.27 & 57.31 \\
\hline
\end{tabular}

\section{Dietary intake}

Place of meal preparation

$\begin{array}{lccccccl}\text { At home } & 12645 & 75.03 & 60 & 58.21 & 0.15 & 57.91 & 58.51 \\ \begin{array}{l}\text { Away from home } \\ \text { Energy (kcal) }\end{array} & 3451 & 24.97 & 57.72 & 55.77 & 0.29 & 55.19 & 56.34 \\ <640 \mathrm{kcal} & & & & & & & \\ 640 \text { a } 880 \mathrm{kcal} & 3697 & 24.31 & 57.37 & 55.26 & 0.26 & 54.74 & 55.78 \\ >880 \mathrm{kcal} & 10699 & 65.81 & 60.52 & 58.67 & 0.17 & 58.35 & 59 \\ & 1700 & 9.88 & 59.97 & 56.75 & 0.44 & 55.89 & 57.62\end{array}$

\section{Regions}

\begin{tabular}{llllllll} 
North & 2303 & 14.31 & 58.31 & 56.45 & 0.66 & 55.16 & 57.75 \\
Northeast & 5832 & 36.23 & 60.00 & 57.92 & 0.44 & 57.06 & 58.79 \\
Midwest & 2290 & 14.23 & 60.93 & 58.54 & 0.69 & 57.18 & 59.90 \\
South & 2033 & 12.63 & 60.00 & 56.78 & 0.67 & 55.46 & 58.09 \\
Southeast & 3638 & 22.60 & 60.33 & 57.03 & 0.54 & 55.95 & 58.10 \\
\hline
\end{tabular}

* Proportion considering the sample design 
Table 3. Brazilian meal quality and MMQI components score. Brazil, 2008-2009.

\begin{tabular}{lccccccc}
\hline & Mean & SE & \multicolumn{1}{c}{ IC 95\% } & P25 & P50 & \multicolumn{1}{c}{ P75 } \\
\hline Fruits & 0.69 & 0.02 & 0.61 & 0.77 & 0.00 & 0.00 & 0.00 \\
Vegetables & 0.79 & 0.02 & 0.72 & 0.87 & 0.00 & 0.00 & 0.00 \\
Carbohydrates & 5.49 & 0.03 & 5.36 & 5.32 & 0.00 & 5.93 & 10.00 \\
Total fat & 7.69 & 0.03 & 7.58 & 7.80 & 6.21 & 10.00 & 10.00 \\
Satured fat & 7.90 & 0.03 & 7.79 & 8.02 & 8.04 & 10.00 & 10.00 \\
Animal protein / total protein & 6.29 & 0.04 & 6.14 & 6.44 & 0.00 & 10.00 & 10.00 \\
Fiber & 4.78 & 0.04 & 4.63 & 4.92 & 0.00 & 4.17 & 10.00 \\
Processed meat & 9.59 & 0.01 & 9.53 & 9.66 & 10.00 & 10.00 & 10.00 \\
Desserts and sugary drinks & 8.68 & 0.02 & 8.58 & 8.78 & 10.00 & 10.00 & 10.00 \\
Energy density & 5.36 & 0.03 & 5.23 & 5.48 & 0.00 & 5.70 & 10.00 \\
Meal quality & 57.28 & 0.30 & 56.68 & 57.87 & 46.64 & 60.00 & 70.00 \\
\hline
\end{tabular}

The average of energy consumption at lunch was $704 \mathrm{kcal}(\mathrm{SD}=300)$, and the mean score of the quality of the meal was 57 points $(\mathrm{SE}=0.30)$, with a median of 60 points (Table 3). Although no difference was observed in the final score among regions, some components had significant difference (Figure 1). Considering the components of the score, the lowest values were observed for the items "fruits" and "vegetables", with median below 1 point. The highest scores were observed for "desserts and sugary drinks" and "processed meats", averaging around nine points each. North region had the best score for the component "fruit" and the worst score for "energy density", while Northeast had the best score for saturated fat. The Midwest was the region with the highest score for "vegetables" and the South had the lowest fiber intake. The Southeast region had intermediate score values for all components (Figure 1). 
Figure 1. Average score of the MMQI components by Brazilian regions. Brazil, 2008-2009.

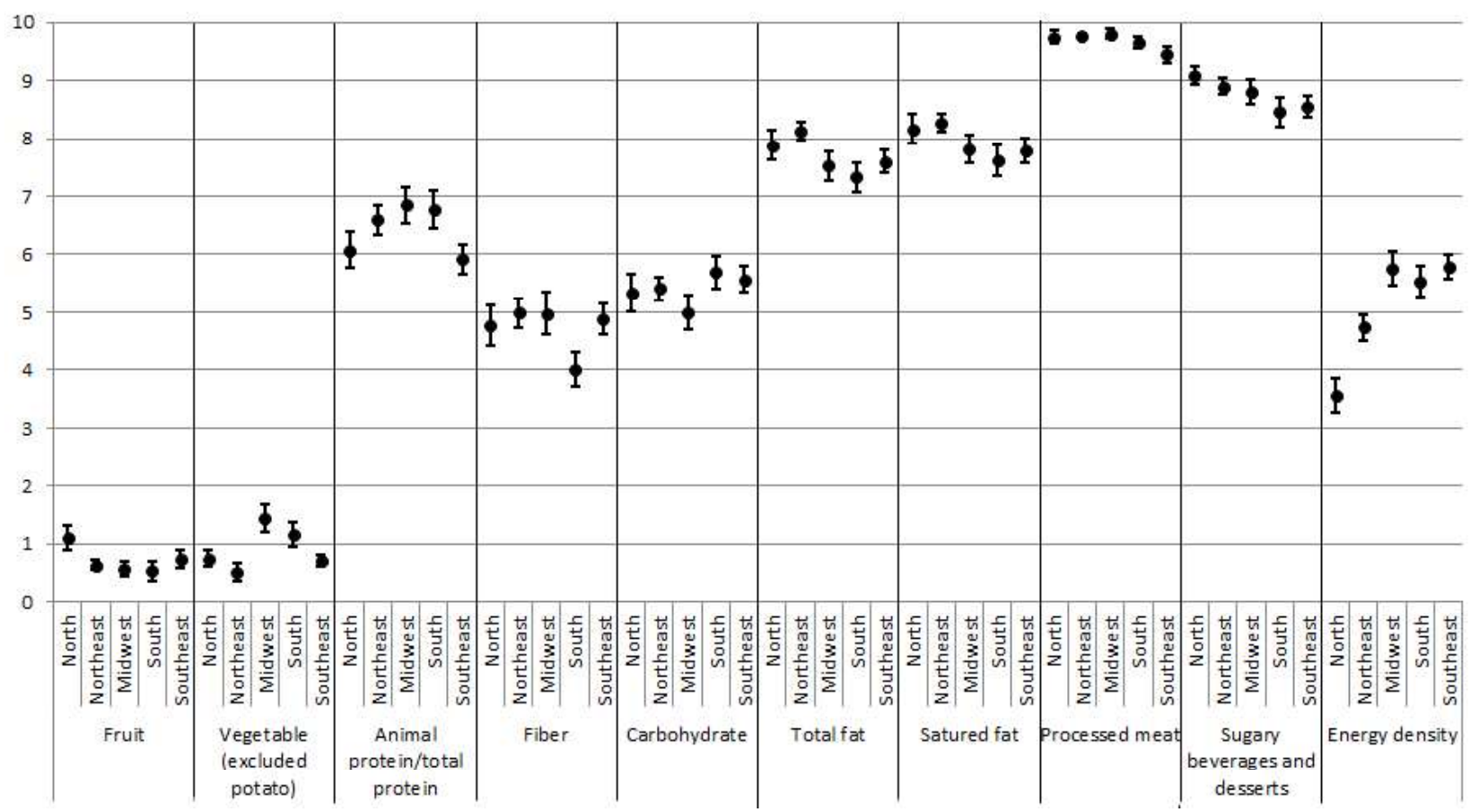

All variables analyzed with the quality of lunch, by regions, both in bivariate models as well as in adjusted models, were described in table 4. North and Northeast lunch quality were associated with gender and education, and Midwest lunch quality was associated with age, while South lunch quality was associated with gender, age and income and Southeast lunch quality was associated with gender, age, education and income. Education and income levels showed low correlation in all regions, the higher value found was 0.18 in Northeast. 
Table 4. Fatores associados a qualidade do almoço dos brasileiros. Brasil, 2008-2009.

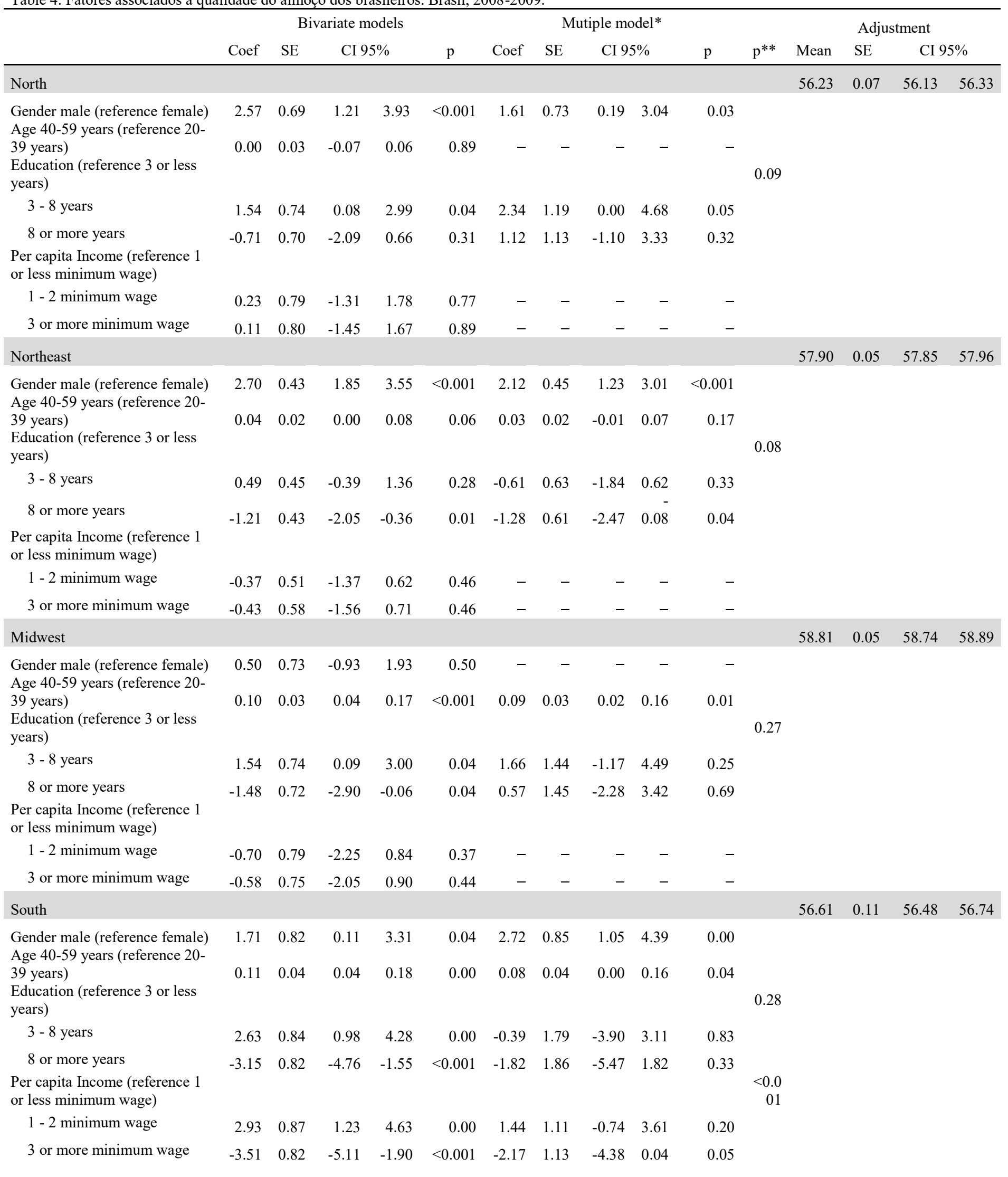




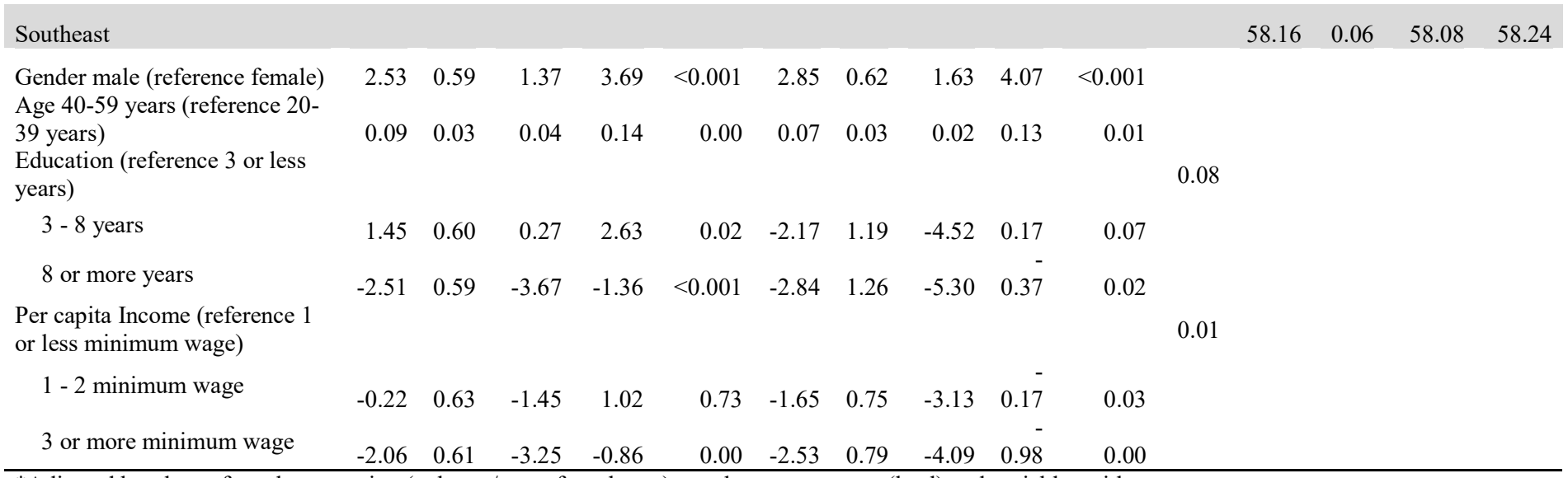

*Adjusted by place of meal preparation (at home/away from home), meal energy content (kcal) and variables with $\mathrm{p}$ value $<0.20$ in bivariate models.

**Wald test

Higher per capita income was associated with a worst lunch quality in South ( 3 or more minimum wage) and in the Southeast (1-2 minimum wage and 3 or more minimum wage), comparing to 1 or less minimum wage. Brazilians with 40-59 years had a higher quality lunch in the Midwest, South and Southeast. In relation to 3 or less years of education, in the North people with 3-8 years of education had a higher MMQI score. In contrast, in Northeastern and Southeast, individuals with 8 or more years of education had a smaller quality of lunch. Men had a better quality lunch in North, Northeast, South and Southeast.

After adjustment by the variables analyzed in the multiple motel, differences in the MMQI mean score could be observed between the regions (Table 4). North had a worst lunch quality, 56 points, while the Midwest had a better lunch quality, around 59 points.

\section{Discussion}


In this study, the mean quality of lunch consumed by Brazilians, measured by the MMQI index, scored 57 points of 100, indicating a poor nutritional quality. It was observed that lunch was characterized by low consumption of fruits and vegetables, corroborating other studies ${ }^{(16,17)}$. At least $50 \%$ of the studied population, in all regions, did not consume any portion of fruit or vegetable at lunch. Only in the North, and Midwest and South regions, the mean scores were higher than one point for the components "fruit" and "vegetable", respectively. Representative data suggest a national average daily intake of $54 \mathrm{Kcal}$ to be derived from fruits, which is less than a portion $(70 \mathrm{kcal}){ }^{(18)}$. According to Malta et al., Midwest and Southeast are the Brazilian regions with higher daily consumption of fruits and vegetables, followed, in a decreasing order, by North, South and Northeast ${ }^{(19)}$. However, the same study appoint Midwest and Southeast also as the regions with the biggest consumption of soft drinks, followed, in a decreasing order, by South, North and Northeast ${ }^{(19)}$.

As expected, there are differences in the lunch consumed by adults among Brazilian regions, with distinctions in its relationships with demographic and socioeconomic factors. In North and Northeast a better lunch quality was associated with be male, and in Midwest a better lunch quality was associated with have 40 years or more; while in South and Southeast a better lunch quality was associated with both, be male and have 40 years or more. Older adults consume more fruits, vegetables, fish, and less fat meats, soft drinks, and sugary foods (16,20); and, comparing with women, males usually eat beans more regularly ${ }^{(16,20)}$. Besides this, in Brazil, although women had consumed more fruits and vegetables, they also consumed less carbohydrate and fiber, and more sugary foods ${ }^{(16,20)}$. 
Higher levels of income and education were associated with worst lunch quality in South and Southeast, and in Northeast and North. In agreement with that, the National Health Survey results showed that Brazilians with higher education level have a higher consumption of sugary foods and added salt, with a lower consumption of beans ${ }^{(16,21)}$. Furthermore, Popkin et al (2012) observed an increase in obesity rates for individuals, with higher income, living in the urban area of developing countries ${ }^{(22)}$. Economic growth and technological developments eventually result in more caloric, palatable, inexpensive and for rapid consumption foods, leading the population to an excessive food intake ${ }^{(13-25)}$.

Although Brazilians are still preparing their own meals, ${ }^{(26)}$ it is observed a decrease acquisition of traditional Brazilian foods and an increase consumption of fast foods. ${ }^{(13,27,28)}$ Between 2003 and 2008, the acquisitions of rice and beans were reduced in $40 \%$ and $26 \%$, respectively; while the acquisition of ready-to-eat preparations and cola drinks were increased in $37 \%$ and $39 \%$, respectively. ${ }^{(13)}$ In this way, aimed to prevent population weight gain and to educate individuals for a healthier diet, in 2014, the Ministry of Health published the new Food Guide for the Brazilian Population; it is the first food guide with guidelines aimed at meals, for both the individual and collective ${ }^{(27)}$. The new guide recommends moderation in the use of food products sold ready for consumption, and encourages the consumption of fresher foods, such as fruits and vegetables.

In our study, most adults did not consume processed meats, desserts and sugary drinks during the lunch. However, Santos et al (2015), studying the lunch of adults living in Sao Paulo, described that, among the five patterns identified, three of 
them (sweetened juices, Western and Meat) were characterized by foods high in sugar, fat, sodium and low in fiber content ${ }^{(7)}$. As described in literature, was observed that lunches away from home had lower quality than lunches prepared at home ${ }^{(9,10)}$. Bezerra et al, comparing daily food consumption at home and away from home, showed that about $40-60 \%$ of the energy from alcohol, soft drinks, snacks, sandwiches and pizzas were consumed away from home ${ }^{(18)}$.

Our study has limitations, and one of these is the use of a single food record. Although the INA has collected two food records, worked with only the first record allowed us to adjust the model for the meal preparation place (at home or away from home), which has been described in literature as a risk factor for obesity ${ }^{(29)}$. In addition, another limitation was to not distinguish the place of consumption of meals eaten away from home in the workplace, school or business. Carus et al. showed that in southern Brazil, about $60 \%$ of meals eaten away from home occur in the workplace $^{(30)}$; and compared to the meals eaten at home, institutional meals presents a lower density energy and a higher fiber content ${ }^{(9)}$.

\section{Conclusion}

One of the principles of the Brazilian National Food and Nutrition Policy is about food and nutritional safety with sovereignty, which is based on the everyone's right to quality food, being based on eating practices that promote health and respect cultural diversity and that are environmentally, culturally, economically and socially sustainable. To achieve this national goal it is of paramount public health importance 
to know the food habits and the sociodemographic differences among Brazilian regions.

In summary, despite the moderate consumption of sugars and fats, the consumption of foods rich in fiber and vitamins, such as fruits and vegetables, were low; with observed differences among the lunch consumed in the regions, with distinctions in its nutritional quality and in its relationships with demographic and socioeconomic factors. North and Northeast lunch quality were associated with gender and education, while south and Southeast lunch quality was associated with gender, age, education and income. Thus, public policies that not only encourage but also provide access and more conditions of acquisition of fruits and vegetables and promotes healthy food systems, including nutrition education and the empowerment of individuals, have clearly shown to be a necessity.

\section{References}

1. Leech RM, Worsley A, Timperio A et al (2015). Understanding meal patterns: definitions, methodology and impact on nutrient intake and diet quality. Nutr Res rev, 28(1), 1-21.

2. Wang WC, Worsley A, Hodgson V (2013). Classification of main meal patterns-a latent class approach. Brit j nutr, 109(12), 2285-96.

3. Ana IA, Schoolmeester D, Dekker M, et al (2007). To cook or not to cook: a means-end study of motives for choice of meal solutions. Food Quality and Preference, 18(1), 77-88. 
4. Fjellström K (2008). Mealtime and meal patterns from a cultural perspective. Food \& Nutr Res, 48(4), 161-4.

5. Hoffmann I (2003). Transcending reductionism in nutrition research. Am j clin nutr, 78(3), 514S-6S.

6. Meiselman HL (2008). Dimensions of the meal. J Foodservice, 19(1), 13-21.

7. Santos RO, Fisberg RM. Marchioni, et al (2015). Dietary patterns for meals of Brazilian adults. Brit J Nutr, 114(5), 822-828.

8. Monfort-Pires M, Ferreira SRG (2016). Modification in a single meal is suficiente to provoke benefits in inflammatory responses of individuals at low-to-moderate cardiometabolic risk. Clin Nutr; doi:101016/jclnu201602015.

9. Bandoni DH, Canella DS, Levy RB, et al (2013). Eating out or in from home: analyzing the quality of meal according eating locations. Rev nutr, 26(6), 625-32.

10. Gorgulho BM, Fisberg RM, Marchioni DML (2013). Nutritional quality of major meals consumed away from home in Brazil and its association with the overall diet quality. Prev Med, 57(2), 98-101.

11. Barros MBA, Francisco PMSB, Zanchetta LM, César CLG (2011). Tendências das desigualdades sociais e demográficas na prevalência de doenças crônicas no Brasil, PNAD: 2003-2008. Ciência \& Saúde Coletiva, 16(9):3755-68.

12. Brazil. Ministry of Health of Brazil. Secretariat of Health Care. Department of Primary Health Care (2013). National Food and Nutrition Policy/ Ministry 
of Health of Brazil, Secretariat of Health Care, Department of Primary Health Care. - Brasilia : Ministry of Health of Brazil.

13. IBGE. Pesquisa de Orçamentos Familiares 2008-2009: análise do consumo alimentar pessoal no Brasil. Rio de Janeiro: IBGE. 2011.

14. Gorgulho BP, Gerda K. Sarti, FM, et al (2016). Measuring quality of meals in different cultural and socioeconomic context: development and validation of a index. In press.

15. Gorgulho BP, Gerda K., Marchioni DML (2016). Evaluation of the Main Meal Quality Index for use in UK. Brit J Nutr, 115(11), 2017-2024.

16. Jaime PC, Stopa SR, Oliveira TP, et al (2015). Prevalência e distribuição sociodemográfica de marcadores de alimentação saudável, Pesquisa Nacional de Saúde, Brasil 2013. Epidemiologia e Serviços de Saúde, 24(2), 267-276.

17. Bigio RS, Verly-Jr E, Castro MA, et al (2011). Determinantes do consumo de frutas e hortaliças em adolescentes por regressão quantílica. Rev Saúde Pública, 45(3), 448-56.

18. Bezerra IN, Souza AM, Pereira RA, et al (2013). Contribution of foods consumed away from home to energy intake in Brazilian urban areas: the 2008-9 Nationwide Dietary Survey. Br J Nutr, 109(7), 1276-83.

19. Malta DC, Andrade SSCA, Stopa SR, et al (2015). Estilos de vida da população brasileira: Pesquisa Nacional de Saúde, Brasil 2013. Epidemiologia e Serviços de Saúde, 24(2), 217-226.

20. Claro RM, Santos MAS, Oliveira TP, et al (2015). Consumo de alimentos não saudáveis relacionados a doenças crônicas não transmissíveis no Brasil: 
Pesquisa Nacional de Saúde, Brasil 2013. Epidemiologia e Serviços de Saúde, 24(2), 257-265.

21. Oliveira MM, Malta DC, Santos MAS, et al (2015). Consumo elevado de sal autorreferido em adultos: Pesquisa Nacional de Saúde, Brasil 2013. Epidemiologia e Serviços de Saúde, 24(2), 249-256.

22. Popkin BM, Adair LS, Ng SW (2012). Global nutrition transition and the pandemic of obesity in developing countries. Nutr rev, 70(1), 3-21.

23. Cutler D, Glaeser E, Shapiro J (2003). Why have Americans become more obese? National Bureau of Economic Research.

24. Finkelstein EA, Ruhm CJ, Kosa KM (2005). Economic causes and consequences of obesity. Annu Rev Public Health, 26, 239-57.

25. Philipson TJ, Posner RA (1999). The long-run growth in obesity as a function of technological change. National bureau of economic research.

26. Moubarac J-C, Claro RM, Baraldi LG, et al (2013). International differences in cost and consumption of ready-to-consume food and drink products: United Kingdom and Brazil, 2008-2009. Global public health, 8(7), 845-56.

27. CGAN (2014). Guia alimentar para a população brasileira. In: Nutrição CGdPdAe, editor. 2 ed. Brasília: Ministério da Saúde.

28. Souza AM, Pereira RA, Yokoo EM, et al (2003). Most consumed foods in Brazil: National Dietary Survey 2008-2009. Rev Saude Publica, 47 Suppl 1, 190s-9s.

29. Bezerra IN, Sichieri R (2009). Eating out of home and obesity: a Brazilian nationwide survey. Public health nutrition, 12(11), 2037-43. 
30. Juliana Pires C, Giovanny V A F, Aluísio J D B (2014). Place and type of meals consumed by adults in medium sized cities. Revista de Saúde Pública, 41(8), 68-74.

\section{CONSIDERAÇÕES FINAIS}

Esta tese teve como objetivo norteador a investigação da qualidade nutricional da principal refeição consumida no Brasil, e sua comparação com a qualidade nutricional da principal refeição consumida no Reino Unido. Ao comparar a principal refeição de dois países em diferentes estágios da transição epidemiológica e nutricional, bem como com diferentes realidades econômicas e tecnológicas, esperava-se identificar hábitos alimentares propícios ao desenvolvimento da obesidade e doenças crônicas não transmissíveis, que pudessem ser modificados.

A partir do relatado no manuscrito 1 , e da proposição do manuscrito 2 , foi possível desenvolver e validar uma ferramenta capaz de avaliar a qualidade nutricional da principal refeição consumida por diferentes populações, permitindo a realização do estudo. Apesar das diferenças culturais, a maioria dos países, assim como as organizações mundiais de saúde, demonstram as mesmas preocupações em relação à alimentação; reduzir o consumo de gorduras, açúcares e sal, e aumentar o consumo de frutas, verduras e legumes.

No manuscrito 3, ao descrever e comparar a composição e qualidade nutricional da principal refeição consumida no Brasil e Reio Unido, observou-se que, embora o Brasil ainda tenha um consumo da principal refeição com qualidade 
nutricional superior ao Reino Unido, os hábitos alimentares de ambos países precisam de melhoras. $\mathrm{O}$ consumo de frutas, verduras e legumes relatado pelas duas populações foi inferior ao recomendado.

Em relação a composição das principais refeições, itens típicos de fast foods, como batata frita, sanduiches e refrigerantes, foram característicos do Reino Unido. Contudo, apesar da refeição brasileira ter se caracterizado pela presença de alimentos tradicionais da nossa cultura, como o arroz e feijão, estudos vem demonstrando a redução da participação destes itens na alimentação das famílias brasileiras. Ademais sabe-se que a aquisição de produtos alimentícios vendidos prontos para o consumo vem crescendo nos últimos anos, inclusive no Brasil. Em países em desenvolvimento, como o Brasil, o aumento na renda familiar permite o acesso a todo tipo de alimento, que antes não eram possíveis de serem adquiridos, incluindo produtos alimentícios industrializados, de elevada densidade energética.

Ainda no manuscrito 3, notou-se associação inversa entre a qualidade da principal refeição consumida no Brasil e o excesso de peso, reforçando a necessidade de adequação dos hábitos alimentares, na tentativa de prevenir o ganho de peso e reduzir o risco para doenças crônicas não transmissíveis. Embora a prevalência de excesso de peso e obesidade já esteja elevada no Brasil (superior aos 50\%), em países como o Reino Unido e os Estados Unidos, com consumo elevado de produtos alimentícios vendidos prontos para o consumo, essa prevalência já ultrapassa os $70 \%$. 
Analisando os dados obtidos no manuscrito 3, julgou-se prudente verificar se os comportamentos observados para o Brasil, como um todo, representavam as grandes regiões brasileiras, norte, nordeste, centro-oeste, sudeste e sul. Dessa forma, no manuscrito 4, observou-se diferentes fatores sociodemográficos determinantes para a qualidade da principal refeição consumida nas grandes regiões. Enquanto as regiões norte, nordeste e sudeste associaram-se a escolaridade, as regiões centrooeste e sul associaram-se a renda. Diferente do esperado, renda e escolaridade não estiveram fortemente correlacionadas.

Apesar das diferenças observadas nos componentes do indicador, as cinco grandes regiões brasileiras apresentaram pontuais finais semelhantes de qualidade da refeição, e todas apresentaram baixo consumo de frutas, verduras e legumes. Destaca-se que, diferente do observado em estudos de padrão alimentar, nas regiões nordeste, sudeste e sul, as mulheres apresentarem pior qualidade da refeição. Esse achado corrobora com os resultados da Pesquisa Nacional de Saúde e caracteriza-se pelo baixo consumo de carboidratos e feijão, e maior consumo de doces, apesar do maior consumo de frutas e verduras.

Por fim, com esta tese reconhece-se a necessidade da melhora da qualidade da principal refeição consumida no Brasil, através: do resgate do consumo de alimentos tradicionais da nossa cultura, como arroz e feijão; da promoção da alimentação saudável, facilitando e permitindo o acesso da população à aquisição de frutas, verduras e legumes; do empoderamento da população, com ações de educação nutricional; e da redução do consumo de itens de alta densidade energética, ricos em gorduras, açúcar e sal. 


\section{REFERÊNCIAS}

Abreu ES, Garbelotti ML, Torres EAFS. Dietary fiber consumption and composition foods in "by-the-kilo" restaurants. Nutr Food Science. 2005; 35(6): 386-392.

Ahluwalia, N., Dwyer, J., Terry, A., Moshfegh, A., Johnson, C. Update on NHANES Dietary Data: Focus on Collection, Release, Analytical Considerations, and Uses to Inform Public Policy. Advances in Nutrition: An International Review Journal, 2016; 7(1), 121-134.

Bandoni DH, Jaime PC. A qualidade das refeições de empresas cadastradas no Programa de Alimentação do Trabalhador na cidade de São Paulo. Rev. Nutr., 2008; 21(2):177-184.

Berge JM, Wickel K, Doherty W. The individual and combined influence of the quality and quantity of family meals on adult body mass index. Families, Systems and Health. 2012;30(4):344-351.

Berry, MJA.; Linoff, G. Data Mining Techniques: For Marketing, Sales, and Customer Support. New York: Wiley Computer Publishing, 1997.

Berry, MJA.; Linoff, G. Mastering Data Mining. John Wiley \& Sons, inc., New York, 2000.

Bes-Rastrollo M, Basterra-Gortari FJ, Sa'nchez-Villegas A, Marti A, Martinez JA, Martinez-Gonzales MA. A prospective study of eating away-from-home meals and weight gain in a Mediterranean population: the SUN (Seguimiento Universidad de Navarra) cohort. Public Health Nutr 2010;13(9):1356-1363.

Bezerra NI, Sichieri R. Eating out of home and obesity: a Brazilian nationwide survey. Public Health Nutrition 2009; 12(11):2037-43. 
Bezerra IN, Souza AM, Pereira RA, Sichieri R. Contribution of foods consumed away from home to energy intake in Brazilian urban áreas: the 2008-9 Nationwide Dietary Survey. Br J Nutr 2012. Doi: 10.1017/S0007114512003169.

Bigio, RS; Verly-Jr, E.; Castro, MA de; César, CLG; Fisberg, RM; Marchioni, DML. Determinantes do consumo de frutas e hortaliças em adolescentes por regressão quantílica. Rev Saúde Pública. 2011; 45: 448-456.

Bhutani S, Varady KA. Nibbling versus feasting: which meal pattern is better for heart disease prevention? Nutr Rev 2009;67:591-8.

Brasil. Ministério da Saúde. Guia alimentar para a população brasileira: promovendo a alimentação saudável. Brasília, DF; 2006.

Brasil. Ministério da Saúde. Secretaria de Atenção à Saúde. Departamento de Atenção Básica. Política Nacional de Alimentação e Nutrição. $2^{\mathrm{a}}$ ed. rev. Brasília: Ministério da Saúde; 2008.

Bueno MB, Marchioni DML, Cesar CLG, Fisberg RM. Added sugars: consumption and associated factors among adults and elderly. São Paulo, Brazil. Rev Bras Epidemiol. 2012; 15(2), 256-264.

Caivano S, Domene SMA. Diet quality índex for healthy food choices. Ver Nytr. 2013; 26(6):693-699.

Cervato AM, Vieira VL. Índices dietéticos na avaliação da qualidade global da dieta. Rev Nutr 2003; 16: 347-355.

Cesar CLG, Carandina L, Alves MCGP et al. Saúde e condições de vida em São Paulo - Inquérito multicêntrico de saúde no Estado de São Paulo. Faculdade de Saúde Pública, USP. 2005.

Colucci ACA, Cesar CLG, Marchioni DML, Fisberg RM. Relação entre o consumo de açúcares de adição e a adequação da dieta de adolescentes do município de São Paulo. Rev Nutr. 2011;24(2):219-231. 
Costa AIA, Schoolmeester D, Dekker M, Jongen WMF. To cook or not to cook: A means-end study of motives for choice of meal solutions. Food Quality and Preference. 2007;18:77-88.

Coutinho JG, Cardoso AJC, Toral N, Silva ACF, Ubarana JA, Aquino KKNC, Nilson EAF, Fagundes A, Vasconcellos AB. A organização da Vigilância Alimentar e Nutricional no Sistema Único de Saúde: histórico e desafios atuais. Rev Bras Epidemiol. 2009; 12(4): 688-99.

Cutler DM, Glaeser EL, Shapiro JM. Why have Americans become more obese? $J$ Econ Perspect 2003; 17: 93-118.

Department of Health. National Diet and Nutrition Survey: Headline results from Years 1 and 2 (combined) of the Rolling programme (2008/09-2009/10). Disponível em:http://dh.gov.uk/prod_consum_dh/groups/dh_digitalassets/documents/digitalasset /dh_128542.pdf(Acesso 10 Junho 2013)

Edelstein SL, Barrett-Connor EL, Wingard DL, Cohn BA. Increased meal frequency associated with decreased cholesterol concentrations; Rancho Bernardo, CA, 19841987. Am J Clin Nutr 1992;55:664-9.

Egger G, Swinburn B. Planet obesity: how we're eating ourselves and the planet to death. Sydney: Allen and Unwin, 2010.

Fabry P, Hejl Z, Fodor J, Braun T, Zvolankova K. The frequency of meals: its relation to overweight, hypercholesterolaemia, and decreased glucosetolerance. Lancet 1964;2:614-5.

Finkelstein EA, Ruhm CJ, Kosa KM. Economic causes and consequences of obesity. Annu Rev Public Health 2005; 26: 239-57.

Fisberg RM, Slater B, Barros RR, Lima FD, César CLG, Carandina L et al. Índice de Qualidade da Dieta: avaliação da adaptação e aplicabilidade. Rev Nutr. 2004; 17(3):301-308. 
Fjellstrom C. Mealtime and meal patterns from a cultural perspective. Scandinavian Journal of Nutrition. 2004;48(4):161-164.

Food Standards Agency. Healthy diet. 8 tips for eating well. 2010. Acesso em agosto 2013. http://www.eatwell.gov.uk/healthydiet/eighttipssection/8tips/

Freitas, A. A. Uma Introdução a Data Mining.Informática Brasileira em Análise. Cesar - Centro de Estudos e Sistemas Avançados do Recife. Ano II, n. 32, mai./jun. 2000

Gama, J. Árvores de Decisão, 2002. Disponível em: http://liacc.up.pt/ jgama/Mestrado/ECD1/Arvores.html. Acesso em: ago. 2013.

Garcia RWD. Reflexos da globalização na cultura alimentar: considerações sobre mudanças na alimentação urbana. Rev Nutr. 2003; 16(4): 483-92.

Gibson, RS. Reproducibility in dietary assessment. In:Principles of nutritional assessment. 2. ed. New York: Oxford Univ. Press, 2005. p. 129-148.

Gorgulho BM, Previdelli AN, Marchioni DML. Qualidade das refeições servidas em uma Unidade de Alimentação e Nutrição de uma indústria da região metropolitana de São Paulo. Rev Nutricão. 2010; 24(3):463-72.

Gorgulho BM, Fisberg RM, Marchioni DML. Nutritional quality of major meals consumed away from home in Brazil and its association with the overall diet quality. Prev Med. 2013; YPMED 3608.

Gorgulho BM, Previdelli AN, Marchioni DML. Qualidade das refeições servidas em uma Unidade de Alimentação e Nutrição de uma indústria da região metropolitana de São Paulo. Rev Nutricão. 2011; 24(3):463-72.

Gravina-Taddei Cf, Batlouni M, Sarteschi C, et al. Hyperhomocysteinemia as a risk factor for coronary atherosclerotic diseases in the elderly. Arq Bras Cardiol. 2005; 85 (3): 166-73. 
Harttig U, Haubrock J, Knüppel S, Boeing H. The MSM program: web-based statistics package for estimating usual dietary intake using the Multiple Source Method on behalf of the EFCOVAL. Consortium European Journal of Clinical Nutrition. 2011; 65, S87-S91.

Haines PS, Siega-Riz M, Popkin BM. The diet quality index revised: a meansurement instrument for populations. J Am Diet Assoc. 1999; 99(6):697- 704.

Hamer M, Mishra GD. Dietary patterns and cardiovascular risk markers in the UK low income diet and nutrition survey. Nutr, Metb and Card Diseases. 2010;20:491497.

Hearty AP, Gibney MJ. Analysis of meal patterns with the use of supervised data mining techniques - artificial neural networks and decision trees. Am J Clin Nutr. 2008; 88: 1632-42.

Hedderley DI, Meiselman HL. Modelling meal acceptability in a free choice environment. Food Qual Pref 1995;6:15-26.

Hoffmann I. Transcending reductionism in nutrition research.AmJ Clin Nutr 2003;78(suppl):514S-6S.

Instituto Brasileiro de Geografia e Estatística - IBGE. Pesquisa de Orçamentos Familiares: Análise do consumo alimentar pessoal no Brasil. Rio de Janeiro; 2011. [acesso em 18 de outubro 2011]. Disponível em <URL: http://www.ibge.gov.br/home/presidencia/noticias/noticia_visualiza.php?id_noticia= 1648\&id_pagina $=1>$.

Jakubowicz D, Froy O, Wainstein J, Boaz M. Meal timing and composition influence ghrelin levels, appetite scores and weight loss maintenance in overweight and obese adults. Steroids 2012;77:323-31.

Kant AK. Indexes of overall diet quality: a review. J. Am. Diet Assoc. 1996; 96: 785-791. 
Kant AK, Graubard BI. Eating out in America, 1987- 2000: trends and nutritional correlates. Prev Med 2004; 38:243-9. 19.

Kant AK, Graubard BI, Mattes RD. Association of food form with self-reported 24-h energy intake and meal patterns in US adults: NHANES 2003-2008. Am Journal of Clinical Nutrition. 2012;96:1369-78.

Kearney JM, Hulshof KFAM, Gibney MJ. Eating patterns temporal distribution, converging and diverging foods, meals eaten inside and outside of the home implications for developing FBDG. Public Health Nutr 2001; 4:693-8.

Kennedy ET, Ohls J, Carlson S, Fleming K. The Healthy Eating Index: design and applications. J Am Diet Assoc 1995;95:1103-8.

Kohavi R, Quinlan R. Decision tree Discovery. In W. Klosgen and J. Zytkow, editors, Handbook of Data Mining and Knowledge Discovery, pages 267-276. Oxford University Press, 2002.

Kulovitz MG, Kravitz LR, Mermier C, Gibson AL, Conn CA, Kolkmeyer D, Kerksick CM. Potential role of meal frequency as a strategy for weight loss and health in overweight or obese adults. Nutrition. 2013; http://dx.doi.org/10.1016/j.nut.2013.08.009 (in press).

Lamboia, F.; Pereira, L. M. Data Mining. Cascavel: Monografia Unioeste. 2005, p. 5 a 20.

Larson NI, Nelson MC, Neumark-Sztainer D, Story M, Hannan PJ> Making time for meals: meal structure and associations with dietary intake in young adults. American Dietetic Association. 2009;109:72-79.

Lassen AD, Biltoft-Jensen A, Hansen GL, Hels O, Tetens I. Development and validation of a new simple Healthy Meal Index for canteen meals. Public Health Nutrition. 2010; 13(10): 1559-1565. 
Leech RM, Worsley A, Timperio A et al. Understanding meal patterns: definitions, methodology and impact on nutrient intake and diet quality. Nutr Res rev 2015, 28(1), 1-21.

Lin B, Frazão E, Guthrie J. Away-from-home foods increasingly important to quality of American diet. Washington DC: Food and Rural Economics Division, Economic Research Service; 1999. (U.S. Department of Agriculture Information Bulletin, 749).

Ma Y, Bertone ER, Stanek EJ 3rd, Reed GW, Hebert JR, Cohen NL, et al. Association between eating patterns and obesity in a free-living US adult population. Am J Epidemiol 2003;15:85-92.

Mansur, ADP, Favarato, D. Mortalidade por doenças cardiovasculares no Brasil e na região metropolitana de São Paulo: atualização 2011; Mortality due to cardiovascular diseases in Brazil and in the metropolitan region of São Paulo: a 2011 update. Arq. bras. Cardiol. 2012; 99(2), 755-761.

Marchioni DML, Claro RM, Levy RB, Monteiro CA. Patters of food aquisition in Brazilian Households and associated factors: a population-based survey. Pub Health Nutr. 2011;14(9):1586-1592.

Marchioni, DML; Mendes, A; Gorgulho, BM; Stella, RH; Fisberg, RM. _Densidade energética da dieta e fatores associados: como está a população de São Paulo?. Arquivos Brasileiros de Endocrinologia e Metabologia. 2013; 56: 638-645.

Meiselman HL. Dimensions of the meal.Journal of foodservice. 2008;19:13-21.

Monteiro CA, Mondini L, Costa RBL. Mudanças na composição e adequação nutricional da dieta familiar nas áreas metropolitanas do Brasil (1988;1996). Rev Saúde Pública. 2000; 34(3):251-8.

Monteiro CA, Levy RB, Claro RM, de Castro RR, Cannon G. Increasing consumption of ultra-processed foods and likely impact on human health: evidence from Brazil. Pub Health Nutr. 2010; 14(1):5-13. 
Moshfegh AJ, Rhodes DG, Baer DJ, Murayi T, Clemens JC, Rumpler WV, Paul DR, Sebastian RS, Kuczynski KJ, Ingwersen LA, Staples RC, Cleveland LE. The US Department of Agriculture Automated Multiple-Pass Method reduces bias in the collection of energy intakes. Am J Clin Nutr. 2008;88(2):324-32.

Moubarac JC, Claro RM, Baraldi LG, Levy RB, Martins APB, Cannon G, Monteiro CA. International differences in cost and consumption of ready-to-consume food and drink products: United Kingdom and Brazil, 2008-2009. Global Public Health. 2013; DOI:10.1080/17441692.2013.796401.

Nutrition Coordinating Center: Division of Epidemiology Nutrition Data System (NDS), 1998. Nutrition Data System for Research (NDS-R), ed. Minnesota: University of Minnesota.

Ocké MC. Evaluation of methodologies for assessing the overall diet: dietary quality scores and dietary patterns analysis. Proceeding of the nutrition society. 2013; doi:10.1017/S0029665113000013.

Offer S. Assessing the relationship between family mealtime communication and adolescent emotional well-being using the experience sampling method. Journal of Adolescence. 2013;36:577-585.

Oltersdorf U, Schlettwein-gsell D, Winkler G. Assessing eating patterns-an emerging research topic in nutritional sciences: introduction to the symposium. Appetite 1999;32:1-7.

Orfanos P, Naska A, Trichopoulus D, et al. Eating out of home and its correlates in 10 European countries. The European Prospective Investigation into Cancer and Nutrition study. Public Health Nutrition 2010; 10(12):1515-25.

Patterson E, Haines PS, Popkin BM. Diet Quality Index: capturing a multidimensional behavior. J Am Diet Assoc 1994; 94:57-64. 
Patterson E, Quetel AK, Lilja K, Simma M, Olsson L, Elinder LS. Design, testing and validation of an innovative web-based instrument to evaluate school meal quality. Public Health Nutrition. 2012;16(6):1028-1036.

Philipson TJ, Posner RA. The long-run growth in obesity as a function of technological change. Perspect Biol Med 2003; 46 (suppl 3): S87-107.

Popkin BM, Adair LS, Ng SW. Global nutrition transition and the pandemic of obesity in developing countries. Nutrition Reviews. 2011;70(1):3-21.

Previdelli AN, Caesar S, Pires MM, Vivolo SRF, Firberg RM, Marchioni DML. Índice de Qualidade da Dieta Revisado (IQD-R): desenvolvimento para aplicação na população brasileira. Cadernos de Saúde Pública. 2011; 45(4): 794-798.

Public Health Agency. Nutrition. 2010. Acesso em agosto 2013. http://www.enjoyhealthyeating.info/primary-links/nutrition

Rennie KL, Jebb SA. Prevalence of obesity in Great Britain. Obesity Reviews. $2005 ; 6: 11-12$.

Rozin P. The meaning of food in our lives: A cross-cultural perspective on eating and well-being. J Nutr Educ Behav. 2005;37:107-112.

Schwarz NA, Rigby BR, La Bounty P, Shelmadine B, Bowden RG. A review of weight control strategies and their effects on the regulation of hormonal balance. $\mathrm{J}$ Nutr Metab 2011;2011:237932.

Scottish Government. Dietary Targets. 2006. Acesso em agosto 2013. http://www.scotland.gov.uk/Topics/Health/health/19133/17756

Skafita V. The family meal panacea: exploring how different aspects of family meal occurrence, mal habits and meal enjoyment relate to Young children's diet. Sociology of Health and Illness. 2013; doi:10.1111/1467-9566.12007. 
Sommer W, Sturmer B, Shmuilovich O, Martin-Loeches M, Schacht A. How about lunch? Consequences of the meal context on cognition and emotion. Plos One. 2013;8(7):e70314.

StataCorp, 2013. Stata Statistical Software: Release 13. College Station, TX: StataCorp LP.

Souza AM, Pereira RA, Yokoo EM, Levy RB, Sichieri R. Alimentos mais consumidos no Brasil: Inquérito Nacional de Alimentação 2008-2009. Ver Saúde Pública. 2013;47(S1):190S-9S.

Tan, PN., Steinbach, M., Kumar, V. Introduction to Data Mining, (First Edition). Addison-Wesley Longman Publishing Co., Inc., Boston, MA, USA; 2005.

Terry T, Atkinson B, e Ripley B. Recursive partitioning and regression trees; 2015. Disponível em: https://cran.r-project.org/web/packages/rpart/rpart.pdf.

Wang WC, Worsley A, Hodgson V. Classification of main meal patterns - a latent class approach. British Journal of Nutrition. 2013;109:2285-2296.

Whitton C, Nicholson SK, Roberts C, Prynne CJ, Pot GK et al. National Diet and Nutrition Survey: UK food consumption and nutrient intake from de first year of the rolling programme and comparisons with previous surveys. British Jounal of Nutrition. 2011;106:1899-1914.

World Cancer Research Fund, American Institute for Cancer Research. Expert report, food, nutrition, physical activity and the prevention of cancer: a global perspective. http://www.dietandcancerreport.org/. Accessed November 26, 2007.

World Health Organization - WHO. Diet, nutrition and the prevention of chronic diseases. WHO technical report series. 2003; 916, 1-60.

World Health Organization - WHO. Global strategy on diet, physical activity and health. Fifty-seventh world health assembly [monograph on the Internet] [WHA57.17]. 2004; Available from http: //who.int/dietphysicalactivity/strategy. 
World Health Organization - WHO. Prevention of cardiovascular disease : guidelines for assessment and management of total cardiovascular risk. Geneva: WHO, 2007.

World Health Organization - WHO. Geneva, 2013 [Acesso em 22 de março de 2013]. Disponível em http://www.who.int/topics/cardiovascular_diseases/en/.

Woteki CE. Integrated NHANES: Uses in National Policy. J Nutr. 2003; 133:582S$584 \mathrm{~S}$.

Ziegler P, Briefel R, Ponza M, Novak T, Hendricks K. Nutrient intakes and food patterns of toddlers' lunches and snacks: influences of location. J Am Dietetic Assoc 2006; 106(1S): 124-34.

Szwarcwald, C. L., Malta, D. C., Pereira, C. A., Vieira, M. L. F. P., Conde, W. L., Souza Junior, P. R. B. D., ... e Lopes, C. D. S. National Health Survey in Brazil: design and methodology of application. Ciência \& Saúde Coletiva, 2014 19(2), 333342.

\section{ANEXOS}




\title{
ANEXO I - PROTOCOLO PARA REVISÃO SISTEMÁTICA
}

\section{Systematic Review Protocol: Instruments of measurement eating quality}

\section{Background}

\begin{abstract}
Although data about meal's composition are scarce in literature, the idea of analyzing the chosen of foods eaten together is not exactly new (Hedderley and Meiselman, 1995; Oltersdorf et al, 1999). It is important to get the maximum of information when analyzing the dietary, trying to consider the current scientific evidence for a dietary pattern that can collaborate in the prevention of chronic diseases, including aspects of its composition, both in nutrient intake and food consumption (Haines et al. 1999 Kant 1996).
\end{abstract}

2. Research Question

Are there indicators to evaluate the meal quality?

3. Review Team

a) Bartira Mendes Gorgulho: PhD Student

b) Dirce Maria Lobo Marchioni: Professor 


\section{Search Strategy}

Search for all studies relating the keywords predefined (Table 1).

Table 1. Key words that will be used in the systematic review. Brazil and UK, 2013.

\begin{tabular}{|c|c|}
\hline Português & Inglês \\
\hline Refeição & Meal \\
Almoço & Lunch \\
Jantar & Dinner \\
Qualidade da refeição & Meal quality \\
Padrão alimentar & Dietary pattern \\
Qualidade da dieta & Dietary quality \\
Índice de alimentação & Eating index \\
saudável & \\
Cardápio de restaurante & Restaurant menu \\
Componentes do cardápio & Menu components \\
Escore para refeições & Meals Score \\
Prato de refeição & Meal plate \\
Serviço de alimentação & Food service \\
\hline
\end{tabular}

5. Selection on Articles

Articles that match the inclusion criteria will be include in the database.

\subsection{Inclusion Criteria}

\subsubsection{Step 1}

The articles that will be included in the systematic review: 
a) Present results for any of the keywords in the title;

b) Are original articles published in indexed journals;

c) Are published in English or Portuguese language;

d) Are published after 1965;

e) Are realized with humans.

\subsubsection{Step 2}

The articles that will be included in the systematic review:

a) Present results for any of the keywords in the abstract;

\subsection{Exclusion Criteria}

Articles that did not present results on development, evaluation or application of methodological instrument aimed to assess the meal quality.

6. Databases

The databases to be searched are: Science Direct, Pubmed, Lilacs, Scielo, Scopus, Cochrane, Embase and Google Scholar.

\section{Hand Searching}

The reference list and bibliographies of the selected articles will be hand searched.

\section{Data Collection}

a) Duplicates Articles will be identified and eliminated using as key terms the first author name, publication year, journal name, volume, starting page number of the article.

b) The complete relevant articles and potentially relevant references that cannot be excluded upon reading the title and abstract will be reviewed. 
c) The assessments of inclusion of articles will be done in duplicate by two independent reviewers.

9. Information of be Extracted

For this review it will be added the variables: authors, years, place, sample, population, instrument of measurement, score, components, guidelines, validation of the instrument, results, relationship with an outcome (if existing).

10. Dissemination of the Findings

The items of the systematic review and its results will be reported in according to the PRISMA statement and checklist (Appendix I).

11. References

1. Haines PS, Siega-Riz M, Popkin BM. The diet quality index revised: a measurement instrument for populations. J Am Diet Assoc. 1999; 99(6):697704.

2. Hedderley DI, Meiselman HL. Modeling meal acceptability in a free choice environment. Food Qual Pref 1995;6:15-26.

3. Kant AK. Indexes of overall diet quality: a review. J. Am. Diet Assoc. 1996; 96: 785-791.

4. Moher D, Liberati A, Tetzlaff J, Altman DG, The PRISMA Group (2009) Preferred Reporting Items for Systematic Reviews and Meta-

5. Analyses: The PRISMA Statement. PLoS Med 6(7): e1000097. doi:10.1371/journal.pmed.1000097

6. Oltersdorf U, Schlettwein-gsell D, Winkler G. Assessing eating patterns-an emerging research topic in nutritional sciences: introduction to the symposium. Appetite 1999;32:1-7. 
7. The PLoS Medicine Editors (2011) Best Practice in Systematic Reviews: The Importance of Protocols and Registration. PLoS Med 8(2): e1001009. doi:10.1371/journal.pmed.1001009

\section{Appendix I}

\begin{tabular}{|c|c|c|c|}
\hline Section/topic & $\#$ & Checklist item & $\begin{array}{l}\text { Reported } \\
\text { on page \# }\end{array}$ \\
\hline \multicolumn{4}{|l|}{ TITLE } \\
\hline Title & 1 & Identify the report as a systematic review, meta-analysis, or both. & \\
\hline \multicolumn{4}{|l|}{ ABSTRACT } \\
\hline Structured summary & 2 & $\begin{array}{l}\text { Provide a structured summary including, as applicable: background; objectives; data sources; study eligibility criteria, } \\
\text { participants, and interventions; study appraisal and synthesis methods; results; limitations; conclusions and } \\
\text { implications of key findings; systematic review registration number. }\end{array}$ & \\
\hline \multicolumn{4}{|l|}{ INTRODUCTION } \\
\hline Rationale & 3 & Describe the rationale for the review in the context of what is already known. & \\
\hline Objectives & 4 & $\begin{array}{l}\text { Provide an explicit statement of questions being addressed with reference to participants, interventions, comparisons, } \\
\text { outcomes, and study design (PICOS). }\end{array}$ & \\
\hline \multicolumn{4}{|l|}{ METHODS } \\
\hline Protocol and registration & 5 & $\begin{array}{l}\text { Indicate if a review protocol exists, if and where it can be accessed (e.g., Web address), and, if available, provide } \\
\text { registration information including registration number. }\end{array}$ & \\
\hline Eligibility criteria & 6 & $\begin{array}{l}\text { Specify study characteristics (e.g., PICOS, length of follow-up) and report characteristics (e.g., years considered, } \\
\text { language, publication status) used as criteria for eligibility, giving rationale. }\end{array}$ & \\
\hline Information sources & 7 & $\begin{array}{l}\text { Describe all information sources (e.g., databases with dates of coverage, contact with study authors to identify } \\
\text { additional studies) in the search and date last searched. }\end{array}$ & \\
\hline Search & 8 & $\begin{array}{l}\text { Present full electronic search strategy for at least one database, including any limits used, such that it could be } \\
\text { repeated. }\end{array}$ & \\
\hline Study selection & 9 & $\begin{array}{l}\text { State the process for selecting studies (i.e., screening, eligibility, included in systematic review, and, if applicable, } \\
\text { included in the meta-analysis). }\end{array}$ & \\
\hline Data collection process & 10 & $\begin{array}{l}\text { Describe method of data extraction from reports (e.g., piloted forms, independently, in duplicate) and any processes } \\
\text { for obtaining and confirming data from investigators. }\end{array}$ & \\
\hline Data items & 11 & List and define all variables for which data were sought (e.g., PICOS, funding sources) and any assumptions and & \\
\hline Section/topic & $\#$ & Checklist item & $\begin{array}{l}\text { Reported } \\
\text { on page \# }\end{array}$ \\
\hline 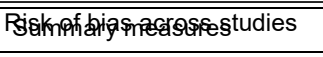 & 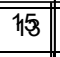 & 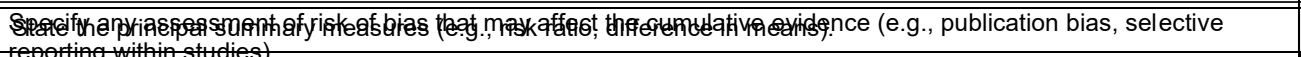 & \\
\hline $\begin{array}{l}\text { Synthesis of results } \\
\text { Additional analyses }\end{array}$ & \begin{tabular}{l||l}
14 \\
16
\end{tabular} & 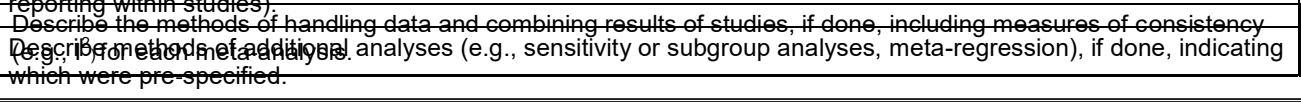 & \\
\hline \multicolumn{4}{|l|}{ RESULTS } \\
\hline Study selection & 17 & $\begin{array}{l}\text { Give numbers of studies screened, assessed for eligibility, and included in the review, with reasons for exclusions at } \\
\text { each stage, ideally with a flow diagram. }\end{array}$ & \\
\hline Study characteristics & 18 & $\begin{array}{l}\text { For each study, present characteristics for which data were extracted (e.g., study size, PICOS, follow-up period) and } \\
\text { provide the citations. }\end{array}$ & \\
\hline Risk of bias within studies & 19 & Present data on risk of bias of each study and, if available, any outcome level assessment (see item 12). & \\
\hline Results of individual studies & 20 & $\begin{array}{l}\text { For all outcomes considered (benefits or harms), present, for each study: (a) simple summary data for each } \\
\text { intervention group (b) effect estimates and confidence intervals, ideally with a forest plot. }\end{array}$ & \\
\hline Synthesis of results & 21 & Present results of each meta-analysis done, including confidence intervals and measures of consistency. & \\
\hline Risk of bias across studies & 22 & Present results of any assessment of risk of bias across studies (see Item 15). & \\
\hline Additional analysis & 23 & Give results of additional analyses, if done (e.g., sensitivity or subgroup analyses, meta-regression [see Item 16]). & \\
\hline \multicolumn{4}{|l|}{ DISCUSSION } \\
\hline Summary of evidence & 24 & $\begin{array}{l}\text { Summarize the main findings including the strength of evidence for each main outcome; consider their relevance to } \\
\text { key groups (e.g., healthcare providers, users, and policy makers). }\end{array}$ & \\
\hline Limitations & 25 & $\begin{array}{l}\text { Discuss limitations at study and outcome level (e.g., risk of bias), and at review-level (e.g., incomplete retrieval of } \\
\text { identified research, reporting bias). }\end{array}$ & \\
\hline Conclusions & 26 & Provide a general interpretation of the results in the context of other evidence, and implications for future research. & \\
\hline \multicolumn{4}{|l|}{ FUNDING } \\
\hline Funding & 27 & $\begin{array}{l}\text { Describe sources of funding for the systematic review and other support (e.g., supply of data); role of funders for the } \\
\text { systematic review. }\end{array}$ & \\
\hline
\end{tabular}




\title{
ANEXO II - VALIDAÇÃO MMQI NO UK (NDNS)
}

\section{Evaluation of the Main Meal Quality Index for use in UK}

Main Meal Quality Index validation in UK

Bartira Mendes Gorgulho ${ }^{1, *}$, Gerda Karolien $\operatorname{Pot}^{2,3,{ }^{*}}$, Dirce Maria Marchioni ${ }^{1, *}$

\begin{abstract}
Objectives. The aim of this study is to evaluate the validity and reliability of the Main Meal Quality Index applied on the United Kingdom population. Methods.The indicator was developed to assess meals quality in different populations, and is composed by 10 components: fruit, vegetable (excluded potatoes), ratio animal protein/total protein, fiber, carbohydrate, total fat, saturated fat, processed meat, sugary beverages and desserts, and energy density, resulting in a score range of 0 100 points. The performance of the indicator was measured using strategies for assessing content validity, construct validity, discriminant validity and reliability; including Principal Components Analysis, linear regression models and Cronbach's Alpha. Results. The indicator presented good reliability. Conclusion.The Main Meal Quality Index has been shown to be valid for used as an instrument to evaluate, monitor and compare the quality of meals consumed by adults in United Kingdom.
\end{abstract}

Key words: meal quality, meal pattern, dietary quality, meal index, meal score.

\section{Introduction}


Despite cultural and social differences, countries and international organizations developed nutritional references and guidelines, applicable to global populations, designed to maintain health status and to prevent increases in the prevalence of dietary-related non-communicable chronic diseases (ref 1-2). Such recommendations are consistently based on high consumption of whole grains, fruits and vegetables, and are associated with reduction of total and saturated fats and added sugar (ref 1-2). In this sense, a series of systematic reviews on the relationship between dietary patterns and health outcomes concluded that consensus on a single indicator, applicable across different populations and health outcomes, is needed (ref 3). Thus, an indicator for assess quality of meals, named Main Meal Quality Index (MMQI), was developed and previously tested in a Brazilian population, where presented valid psychometric characteristics (ref 5).

The MMQI is composed by 10 components: fruit, vegetable (excluded potatoes), animal protein/total protein ratio, fiber, carbohydrate, total fat, saturated fat, processed meat, sugary beverages and desserts, and energy density. Each component can score between zero and 10 points and the final score range is $0-100$ points (ref 5). The components criteria and score were based on the World's Health Organization (ref 1) and World's Cancer Research Fund guidelines (ref 2), adapting the overall nutritional dietary recommendations to the main meal (ref 5). Considering the nutrient content, a main meal should provide at least $30 \%$ of the daily nutritional recommendations (ref 6).

Meals are eating occasions, essential in several aspects of human life: they not only provide nutrients and energy at a biological level, but they also embed 
cultural and socioeconomic dimensions at societal level. Although diverse studies have shown evidence that food consumption patterns referring to main meals are associated with lifestyle factors, food choice, nutrient intake and metabolism (ref 6), there is a lack of consistency and standardization among studies examining meals and meals patterns, its determinants and consequences.

However, although the use of the same indicator enable to compare countries in different epidemiological and income stages, it is required to evaluate the validity and reliability for each country (ref 4). The aim of this study is evaluate the validity and reliability of the Main Meal Quality Index (MMQI) application on the United Kingdom population.

\section{Materials and methods}

\section{Data analysis}

Cross-sectional study with a probabilistic sample in the United Kingdom, made up of 2726 individuals aged between 12 years or more, of both gender, who provided complete interviews (excluded pregnant), taking part in the National Diet and Nutrition Survey. Details of the sample and the data collection from this study have been previously published (ref 7). Data on characteristics of the population were obtained using a questionnaire, and food intake using a 4-day food diary. Meals were named in according to the time slot, and the main meal of the day was defined as the meal that most contributed with energy during the day, in this case, the dinner $(18-21 h)$. 
The performance of the MMQI was measured using strategies for assessing content validity, construct validity and reliability, as proposed by Guenther et al (ref 4).

Construct

The correlation of the MMQI score with selected nutrients (intake at the main meal and overall day) and plasma biomarkers (total cholesterol (mg/dl), triglycerides $(\mathrm{mg} / \mathrm{dl})$ and fasting glucose $(\mathrm{mg} / \mathrm{dl})$ using univariate linear regression models, adjusted by gender and age were investigated. Principal Component Analysis (PCA) was carried out, based on the correlation between the 10 components, to verify whether the structure of the MMQI has another dimension. All of the items were considered in the analysis and the matrix was obtained using varimax rotation. The criteria suggested by Kaiser (ref 8), considering only eigenvalues above one, were used to choose the number of factors to be kept in the model. The auxiliary method used was the Scree test: the dispersion of the number of factors was analyzed until the individual variance curve for each factor became horizontal or dropped sharply (ref 9).

Reliability

The Cronbach's Alpha was used to determine the internal consistency and average correlation of the components (ref 10). The higher the alpha, the greater the reliability of the scale; in this case, the sum of the scores of the items considered. Value $\geq 0.7$ shows acceptable reliability, although in the literature inter item correlations $>0.6$ are accepted (ref 11$)$.

Discrimination between groups 
To assess the ability to distinguish between groups with known differences in the dietary quality, the MMQI and its components were compared in terms of average scores between smokers and nonsmoker's adults (Wald's test).

The analyses were performed using the statistical software Stata (Stata Corp., 13 version, College Station) and the significance level was 5\%. The project was approved by the Research Ethics Committee of the School of Public Health, University of São Paulo.

\section{Results}

Table 1. Main Meal Quality Index components, standards for scoring and average values. UK (2008/09-2011/12).

\begin{tabular}{|c|c|c|c|c|c|c|c|c|c|}
\hline Component & $\begin{array}{c}\text { Standard for } \\
\text { maximum score }(10 \\
\text { points })\end{array}$ & $\begin{array}{c}\text { Standard for } \\
\text { minimum score }(0 \\
\text { points })\end{array}$ & Mean & SEM $^{\mathrm{a}}$ & $\begin{array}{r}95 \% \\
\text { Inte } \\
\end{array}$ & $\begin{array}{l}\text { Conf. } \\
\text { rval }\end{array}$ & $\mathrm{P} 25$ & $\mathrm{P} 50$ & $\mathrm{P} 75$ \\
\hline Fruit & $\geq 80 \mathrm{~g}$ & $\leq 0 \mathrm{~g}$ & 1.54 & 0.07 & 1.40 & 1.69 & 0.00 & 0.00 & 1.56 \\
\hline $\begin{array}{l}\text { Vegetable (excluded } \\
\text { potato) }\end{array}$ & $\geq 160 \mathrm{~g}$ & $\leq 80 \mathrm{~g}$ & 2.61 & 2.61 & 2.40 & 2.83 & 0.00 & 0.00 & 3.90 \\
\hline $\begin{array}{l}\text { Animal protein/total } \\
\text { protein }\end{array}$ & $\leq 80 \%$ & $100.00 \%$ & 9.44 & 0.04 & 9.35 & 9.52 & 10.00 & 10.00 & 10.00 \\
\hline Fiber & $\geq 10 \mathrm{~g}$ & $\leq 7 \mathrm{~g}$ & 3.88 & 0.13 & 3.62 & 4.13 & 0.00 & 0.00 & 10.00 \\
\hline Carbohydrate & $\begin{array}{l}\geq 55 \% \text { of total } \\
\text { energy }\end{array}$ & $\begin{array}{c}\leq 40 \% \text { of total } \\
\text { energy }\end{array}$ & 3.85 & 0.11 & 3.63 & 4.06 & 0.00 & 3.36 & 8.60 \\
\hline Total fat & $\begin{array}{c}\leq 30 \% \text { of total } \\
\text { energy }\end{array}$ & $\begin{array}{c}\geq 40 \% \text { of total } \\
\text { energy }\end{array}$ & 4.81 & 0.11 & 4.59 & 5.04 & 0.00 & 4.60 & 10.00 \\
\hline Satured fat & $\begin{array}{c}\leq 10 \% \text { of total } \\
\text { energy }\end{array}$ & $\begin{array}{c}\geq 13 \% \text { of total } \\
\text { energy }\end{array}$ & 4.62 & 0.12 & 4.38 & 4.86 & 0.00 & 3.41 & 10.00 \\
\hline Processed meat & 0 portion & $\geq 1$ portion & 9.52 & 0.03 & 9.47 & 9.57 & 9.47 & 10.00 & 10.00 \\
\hline $\begin{array}{l}\text { Sugary beverages and } \\
\text { desserts }\end{array}$ & 0 portion & $\geq 1$ portion & 8.19 & 0.79 & 8.03 & 8.35 & 6.93 & 9.77 & 10.00 \\
\hline Energy density & $\leq 1.25 \mathrm{kcal} / \mathrm{g}$ & $\geq 1.65 \mathrm{kcal} / \mathrm{g}$ & 4.12 & 0.11 & 3.90 & 4.35 & 0.00 & 1.58 & 9.35 \\
\hline Final score & - & - & 52.59 & 0.43 & 51.74 & 53.44 & 39.49 & 50.45 & 62.79 \\
\hline
\end{tabular}

$\mathrm{SEM}^{\mathrm{a}}$ : standart error of the mean

The Main Meal Quality Index (MMQI) score presented normal distribution (Table 1). The final score was positively associated $(\mathrm{p}<0.05)$ with the nutrients carbohydrate, protein, vitamins A, C, B6, and folate, iron, magnesium, zinc, calcium 
and potassium, and negatively associated $(\mathrm{p}<0.05)$ with energy, fat, saturated fat, cholesterol and sodium in both situations, in associations with the nutrients intake at the main meal and over the day (Table 2). Total cholesterol was also negatively associated with the MMQI ( $\beta-0.89 ; \mathrm{p}=0.04)$, adjusted by gender and age (results not shown).

Table 2. Association between MMQI and nutrients intake. UK (2008/09-2011/12).

\begin{tabular}{|c|c|c|c|c|c|c|c|}
\hline \multicolumn{4}{|c|}{ Main meal nutrients intake } & \multicolumn{4}{|c|}{ Daily nutrients intake } \\
\hline Nutrients & $\beta^{*}$ & $95 \% \mathrm{CI}$ & $\mathrm{p}$ & Nutrients & $\beta^{*}$ & $95 \% \mathrm{CI}$ & $\mathrm{p}$ \\
\hline Energy (Kcal) & 0.01 & 0.020 .01 & 0.001 & Energy (Kcal) & 0.01 & 0.020 .01 & 0.001 \\
\hline Total fat (g) & 1.67 & 1.771 .57 & $<0.001$ & Total fat (g) & 0.21 & 0.250 .18 & $<0.001$ \\
\hline Carbohydrate (g) & 0.39 & $0.35 \quad 0.44$ & $<0.001$ & Carbohydrate (g) & 0.01 & $\begin{array}{l}0.01- \\
0.03\end{array}$ & 0.001 \\
\hline Protein $(g)$ & 0.25 & 0.180 .33 & $<0.001$ & Protein (g) & 0.02 & $\begin{array}{l}-0.02- \\
0.5\end{array}$ & 0.330 \\
\hline Cholesterol (mg) & 0.04 & $005 \quad 0.03$ & $<0.001$ & Cholesterol (mg) & $\overline{-}-\overline{1}$ & 0.020 .01 & 0.001 \\
\hline Satured fat (g) & 2.67 & $2.87 \quad 2.47$ & $<0.001$ & Satured fat (g) & 0.59 & $\begin{array}{lll}0.67 & 0.52\end{array}$ & $<0.001$ \\
\hline Vitamin A (RE) & 0.01 & $\begin{array}{ll}0.01 & 0.02\end{array}$ & $<0.001$ & Vitamin A (RE) & 0.01 & 0.010 .02 & $<0.001$ \\
\hline Vitamin E (mg) & 0.44 & $0.07 \quad 0.96$ & 0.093 & Vitamin E (mg) & 0.05 & 0.010 .09 & 0.011 \\
\hline Vitamin C (mg) & 0.23 & $0.20 \quad 0.26$ & $<0.001$ & Vitamin C (mg) & 0.2 & 0.010 .03 & $<0.001$ \\
\hline Thiamin (mg) & 11.98 & $8.73 \quad 15.24$ & $<0.001$ & Thiamin (mg) & 0.09 & $\begin{array}{l}8.73 \\
15.24\end{array}$ & 0.218 \\
\hline Riboflavin (mg) & 1.28 & 5.312 .75 & 0.533 & Riboflavin (mg) & 0.12 & $0.05 \quad 0.30$ & 0.166 \\
\hline Vitamin B6 (mcg) & 15.66 & $\begin{array}{l}13.29 \\
18.04\end{array}$ & $<0.001$ & Vitamin B6 (mcg) & 0.17 & $0.01 \quad 0.33$ & 0.050 \\
\hline $\begin{array}{l}\text { Vitamin B12 } \\
(\mathrm{mcg})\end{array}$ & 0.46 & $0.84 \quad 0.07$ & 0.022 & $\begin{array}{l}\text { Vitamin B12 } \\
(\mathrm{mcg})\end{array}$ & 0.04 & $0.03 \quad 0.11$ & 0.283 \\
\hline Total folate $(\mathrm{mcg})$ & 0.14 & 0.120 .16 & $<0.001$ & Total folate $(\mathrm{mcg})$ & 0.01 & 0.010 .02 & $<0.001$ \\
\hline Iron (mg) & 3.29 & 2.703 .88 & $<0.001$ & Iron (mg) & 0.1 & $\begin{array}{ll}0.01 & 0.18\end{array}$ & 0.030 \\
\hline Magnesium (mg) & 0.32 & 0.290 .35 & $<0.001$ & Magnesium (mg) & 0.03 & $0.03 \quad 0.04$ & $<0.001$ \\
\hline Zinc (mg) & 1.36 & 0.871 .85 & $<0.001$ & Zinc (mg) & 0.22 & $\begin{array}{c}0.05- \\
0.38\end{array}$ & 0.009 \\
\hline Calcium (mg) & 0.01 & 0.020 .01 & $<0.001$ & Calcium (mg) & $\overline{-}-\overline{0}$ & $0.01 \quad 0.01$ & 0.182 \\
\hline Potassium (mg) & 0.02 & 0.020 .03 & $<0.001$ & Potassium (mg) & 0.01 & $\begin{array}{ll}0.01 & 0.01\end{array}$ & $<0.001$ \\
\hline Sodium (mg) & 0.01 & $\begin{array}{lll}0.01 & 0.01 \\
\end{array}$ & 0.048 & Sodium (mg) & 0.01 & $\begin{array}{lll}0.01 & 0.01\end{array}$ & 0.050 \\
\hline
\end{tabular}


The scree plot of the PCA showed the presence of four factors with eigenvalues $>1$, representing $65 \%$ of total variance in the index (results not shown). The value of Cronbach's alpha was 0.61 and the correlations between the components' scores and the final score were weak (results not shown).

Furthermore, differences $(\mathrm{p}<0.01)$ between smokers (51 points) and nonsmokers (54 points) were observed (results not shown).

\section{Discussion}

The MMQI was developed aiming to propose one indicator able to assess quality of meals consumed in different populations, independently of cultural and social context, making possible the comparison of countries around the world. Considering this objective, the MMQI was originally based on international standards references and guidelines, and have its performance evaluated in distinguished population, previously in Brazil (ref 5) and now in UK, showing good reliability and validity in both samples. When compared, the results of the MMQI evaluation in Brazilian and British sample were similar (ref 5).

The higher the MMQI final score, the better the meal quality consumed. Therefore, as expected, the MMQI was positively associated with nutrients considered healthy and it was negatively associated with nutrients considered unhealthy.

The PCA provides evidence that no one single linear combination of the MMQI components accounts for almost all co-variation proportion in dietary patterns observed in this sample and the Cronbach's alpha indicated the presence of an acceptable internal consistency. The indicator could distinguish groups with 
known differences in dietary quality, in this sample smokers had a worse quality diet, consistent with previous literature (ref 4).

The MMQI presented good reliability and has been shown to be valid for used as an instrument to evaluate, monitor and compare the quality of meals consumed by adults in UK.

\section{References}

1. World Health Organization. Diet, nutrition and the prevention of chronic diseases. WHO technical report series. 2003(916):1-60.

2. Glade MJ. Food, nutrition, physical activity, and the prevention of cancer: a global perspective. American Institute for Cancer Research/World Cancer Research Fund, American Institute for Cancer Research. 1997:523-526.

3. U.S. Departament of Agriculture. A Series of Systematic Reviews on the Relantioship Between Dietary Patterns and Health Outcomes. Center for Nutrition Policy and Promotion.USDA; 2015.

4. Guenther PM, Reedy J, Krebs-Smith SM, Reeve BB. Evaluation of the Healthy Eating Index-2005. Journal of the American Dietetic Association. 2008;108(11):1854-1864.

5. Gorgulho B, Pot GK, Sarti FM, Fisberg RM, Marchioni DM. Measuring quality of meals: development and validation of a meal quality index. Bitr $J$ Nutr, in press. 
6. Leech RM, Worsley A, Timperio A, McNaughton SA. Understanding meal patterns: definitions, methodology and impact on nutrient intake and diet quality. Nutrition Research Reviews. 2015, 28:1-21.

7. Public Health England, Food Standards Agency. National Diet and Nutrition Survey: results from Years 1 to 4 (combined) of the rolling programme for 2008 and 2009 to 2011 and 2012. UK Data Archive; 2014. Available at: https://www.gov.uk/government/statistics/national-diet-and-nutrition-surveyresults-from-years-1-to-4-combined-of-the-rolling-programme-for-2008-and2009-to-2011-and-2012.

8. Kaiser HF. The varimax criterion for analytic rotation in factor analysis. Psychometrika. 1958;23(3):187-200.

9. Cattell RB. The scree test for the number of factors. Multivariate behavioral research. 1966;1(2):245-276.

10. Cronbach LJ. Coefficient alpha and the internal structure of tests. psychometrika. 1951;16(3):297-334.

11. Santos JRA. Cronbach's alpha: A tool for assessing the reliability of scales. Journal of extension. 1999;37(2):1-5. 


\title{
ANEXO III - VALIDAÇÃO MMQI BRASIL (INA/POF 2008/09)
}

\author{
Cronbach's alpha 0.64
}

Table 2. Association between MMQI score of the main meal and nutrients. Brazil, 2008/09.

\begin{tabular}{lcccc}
\hline & \multicolumn{4}{c}{ Brazil } \\
& $\beta^{*}$ & $95 \%$ CI & $\mathrm{p}$ \\
\hline Total fat (g) & 0.01 & 0.02 & 0.01 & $<0.001$ \\
Carbohydrate (g) & 0.01 & 0.01 & 0.02 & $<0.001$ \\
Protein (g) & 0.01 & 0.02 & 0.01 & 0.020 \\
Cholesterol (mg) & 0.01 & 0.02 & 0.01 & $<0.001$ \\
Satured fat (g) & 0.02 & 0.03 & 0.02 & $<0.001$ \\
Vitamin A (RE) & 0.01 & 0.01 & 0.02 & 0.013 \\
Vitamin E (mg) & 0.01 & 0.01 & 0.02 & $<0.001$ \\
Vitamin C (mg) & 0.01 & 0.02 & 0.01 & 0.055 \\
Thiamin (mg) & 0.11 & 0.014 & 0.08 & $<0.001$ \\
Riboflavin (mg) & 0.04 & 0.05 & 0.02 & $<0.001$ \\
Vitamin B6 (mcg) & 0.08 & 0.11 & 0.06 & $<0.001$ \\
Vitamin B12 (mcg) & 0.01 & 0.02 & 0.01 & 0.004 \\
Total folate (mcg) & 0.01 & 0.01 & 0.01 & $<0.001$ \\
Iron (mg) & 0.02 & 0.01 & 0.02 & $<0.001$ \\
Magnesium (mg) & 0.01 & 0.01 & 0.01 & 0.001 \\
Zinc (mg) & 0.01 & 0.01 & 0.01 & $<0.001$ \\
Calcium (mg) & 0.01 & 0.01 & 0.01 & 0.246 \\
Potassium (mg) & 0.01 & 0.01 & 0.02 & $<0.001$ \\
Sodium (mg) & 0.01 & 0.02 & 0.01 & $<0.001$ \\
\hline
\end{tabular}

* Adjusted by gender and age (years) 
ANEXO IV - COMITE DE ÉTICA EM PESQUISA 


\section{FACULDADE DE SAÚDE PÚBLICA DA UNIVERSIDADE DE SÃO PAULO}

\section{PARECER CONSUBSTANCIADO DO CEP}

\section{DADOS DO PROJETO DE PESQUISA}

Título da Pesquisa: QUALIDADE DA REFEIÇÃO: BRASIL E REINO UNIDO

Pesquisador: Bartira mendes Gorgulho

Área Temática:

Versão: 1

CAAE: 22838213.4 .0000 .5421

Instituição Proponente: Faculdade de Saúde Pública da Universidade de São Paulo - FSP/USP

Patrocinador Principal: Financiamento Próprio

\section{DADOS DO PARECER}

Número do Parecer: 498.683

Data da Relatoria: $18 / 10 / 2013$

\section{Apresentação do Projeto:}

Trata-se de um estudo transversal, de base populacional, por meio de inquérito domiciliar. O presente projeto terá duas etapas: 1) revisão sistemática da literatura sobre índices de qualidade de refeição e subsequente proposição de um indicador para uso na presente pesquisa; 2) Avaliação de padrões de refeição do Brasil e Reino Unido, a partir de dados das pesquisas intituladas ¿Pesquisa de Orçamentos Familiares 2008/09 conduzida no Brasil e National Diet and Nutrition Survey, conduzida no Reino Unido. A revisão sistemática da literatura será realizada em bases de dados eletrônicas, em periódicos indexados, de acordo com unitermos predefinidos. A seguir, com base nesses resultados e também nas recomendações brasileira, britânica e internacional para alimentação saudável, será proposto indicador para qualidade da refeição. Os indivíduos foram questionados no domicilio por entrevistadores treinados. Foi aplicado o questionário sobre condições sociodemográficas e inquérito alimentar. O consumo alimentar foi medido por meio do auto-preenchimento de registros alimentares, sendo duas medidas em dias não consecutivos para entrevistados pela POF 2008/09 e quatro medidas (dois dias de semana e dois de final de semana) para entrevistados pelo NDNS. Orientou-se a anotação sob a forma de medidas caseiras, o preenchimento dos horários e locais das refeições (dentro ou fora do lar), e a descrição detalhada de todos os alimentos e bebidas consumidos; incluindo o modo de preparo, os ingredientes e as marcas comerciais. Serão utilizadas duas diferentes abordagens para a

Endereço: Av. Doutor Arnaldo, 715

Bairro: Cerqueira Cesar CEP: $01.246-904$

UF: SP Município: SAO PAULO

Telefone: (11)3061-7779 Fax: (11)3061-7779 E-mail: coep@fsp.usp.br 


\section{FACULDADE DE SAÚDE PÚBLICA DA UNIVERSIDADE DE SÃO PAULO}

Continuação do Parecer: 498.683

identificação e avaliação da qualidade do almoço: (1) abordagem híbrida, com a identificação dos padrões das refeições por meio de técnicas de redução de dados, e (2) abordagem dirigida pela hipótese, através da aplicação do novo índice de qualidade da refeição. Este trabalho busca testar a hipótese que o Brasil apresenta melhor qualidade nutricional de refeições, devido ao hábito ainda prevalente de preparo de refeições e menor consumo de alimentos processados e refeições prontas, comparados ao Reino Unido.

\section{Objetivo da Pesquisa:}

Objetivo Primário

. Caracterizar e comparar a qualidade nutricional da refeição almoço de adultos residentes no Brasil e Reino Unido.

\section{Objetivo Secundário}

. Revisar os índices de qualidade nutricional da dieta e refeição já existentes;

. Propor um índice de qualidade da refeição para uso em estudos epidemiológicos;

. Identificar o padrão de almoço consumido por adultos residentes no Brasil;

. Identificar o padrão de almoço consumido por adultos residentes no Reino Unido;

. Avaliar a qualidade do almoço consumido por adultos residentes no Brasil;

- Avaliar a qualidade do almoço consumido por adultos residentes no Reino Unido;

. Comparar a qualidade do almoço consumido por adultos residentes no Brasil com o a qualidade do almoço consumido por adultos residentes no Reino Unido;

\section{Avaliação dos Riscos e Benefícios:}

Trata-se de estudo de revisão sistemática seguido por análise de dados secundários não incorrendo assim sem qualquer risco pois não haverá coleta de dados direta.

Benefícios: A alimentação é considerada pela Organização Mundial da Saúde um dos principais fatores de risco modificáveis para DCNT, ressaltando a importância do entendimento dos hábitos alimentares e seus determinantes no atual cenário epidemiológico. Entretanto, são poucos os estudos que se propõem a avaliar, em nível populacional, as características das refeições, bem como seu impacto na qualidade global da dieta. Assim, considerando suas diferenças diante da transição nutricional e desenvolvimento econômico, ao investigar e comparar as características nutricionais das refeições no Brasil e Reino Unido, proposta deste trabalho, espera-se contribuir preenchendo uma lacuna do conhecimento, de forma a oferecer subsídios para o planejamento e implementação de ações de promoção da alimentação saudável.

Endereço: Av. Doutor Arnaldo, 715

Bairro: Cerqueira Cesar CEP: $01.246-904$

UF: SP Município: SAO PAULO

Telefone: (11)3061-7779 Fax: (11)3061-7779 E-mail: coep@fsp.usp.br 


\section{FACULDADE DE SAÚDE PÚBLICA DA UNIVERSIDADE DE SÃO PAULO}

Continuação do Parecer: 498.683

\section{Comentários e Considerações sobre a Pesquisa:}

Trata-se de estudo de revisão sistemática acompanhado de análise de inquéritos populacionais transversais que incluíram questões sobre padrão alimentar de indivíduos residentes no Brasil e no Reino Unido. Por ser a alimentação considerada pela Organização Mundial da Saúde um dos principais fatores de risco modificáveis para DCNT torna-se importante conhecer, em nível populacional, as características das refeições e seu impacto na qualidade global da dieta. Os resultados desse estudo poderão contribuir com uma lacuna do conhecimento, de forma a oferecer subsídios para o planejamento e implementação de ações de promoção da alimentação saudável. Com ele será possível verificar a qualidade da refeição no Brasil e Reino Unido e identificar o padrão alimentar de refeições no Brasil e Reino Unido.

\section{Considerações sobre os Termos de apresentação obrigatória:}

Há solicitação de dispensa do TCLE por tratar-se de estudo de revisão seguido de análise de dados secundários.

\section{Recomendações:}

\section{Conclusões ou Pendências e Lista de Inadequações:}

O projeto está bem descrito, segue os princípios metodológicos desse tipo de pesquisa e não fere princípios éticos.

\section{Situação do Parecer:}

Aprovado

\section{Necessita Apreciação da CONEP:}

Não

\section{Considerações Finais a critério do CEP:}

SAO PAULO, 17 de Dezembro de 2013

\section{Assinador por:}

Sandra Roberta Gouvea Ferreira Vivolo

(Coordenador) 


\section{ANEXO V - CURRÍCULO LATTES}

\section{Bartira Mendes Gorgulho}

Curriculum Vitae

Dados pessoais

$\begin{array}{ll}\text { Nome } & \text { Bartira Mendes Gorgulho } \\ \text { Filiação } & \text { Dimas Roberto Gorgulho e Silvia Cassia Areias Mendes Gorgulho } \\ \text { Nascimento } & 03 / 01 / 1986 \text { - São Paulo/SP - Brasil }\end{array}$

Formação acadêmica/titulação

2013

Doutorado em Nutrição em Saúde Pública.

Faculdade de Saúde Pública, FSP, Brasil

Título: DIFERENÇAS E SIMILARIDADES NA QUALIDADE DA REFEIÇÃO DO BRASIL E REINO UNIDO: QUE LIÇÕES PODEMOS APRENDER?

Orientador: Dirce Maria Lobo Marchioni

Bolsista do(a): Fundação de Amparo à Pesquisa do Estado de São Paulo

2011 - 2012 Mestrado em Nutrição em Saúde Pública.

Faculdade de Saúde Pública, FSP, Brasil

Título: ALIMENTAÇÃO FORA DO LAR E SUA RELAÇÃO COM A QUALIDADE DA DIETADE MORADORES DO MUNICÍPIO DE SÃO

PAULO: ESTUDO ISA-Capital, Ano de obtenção: 2012

Orientador: Dirce Maria Lobo Marchioni

Bolsista do(a): Fundação de Amparo à Pesquisa do Estado de São Paulo

$2006-2010$

Graduação em Nutrição.

Faculdade de Saúde Pública, FSP, Sao Paulo, Brasil

Título: Qualidade das refeições servidas em uma Unidade de Alimentação e

Nutrição de uma indústria da região metropolitana de São Paulo

Bolsista do(a): Fundação de Amparo à Pesquisa do Estado de São Paulo

\section{Formação complementar}


$2016-2016$

$2015-2015$

$2014-2014$

$2013-2013$

$2011-2011$

$2010-2010$

2009 - 2009

$2007-2007$

$2007-2007$
Curso de curta duração em Introdução à análise de dados lingitudinais. (Carga horária: $20 \mathrm{~h})$.

Faculdade de Saúde Pública, FSP, Brasil

Extensão universitária em Introdução a Big Data em saúde. (Carga horária: 20h).

Faculdade de Saúde Pública, FSP, Brasil

Curso de curta duração em Análise Multinivel em Estudos Epidemiológicos.

(Carga horária: 20h).

Faculdade de Saúde Pública, FSP, Brasil

Curso de curta duração em EndNote Basic. (Carga horária: 4h).

Faculdade de Saúde Pública, FSP, Brasil

Curso de curta duração em Modelagem com Equações Estruturais. (Carga horária: $20 \mathrm{~h})$.

Faculdade de Saúde Pública, FSP, Brasil

Curso de curta duração em Training on food composition \& biodiversity indica.

(Carga horária: 40h).

Faculdade de Saúde Pública, FSP, Brasil

Curso de curta duração em Pacote estatístico STATA - versão 9. (Carga horária: 20h).

Faculdade de Saúde Pública, FSP, Brasil

Bolsista do(a): Pró-Reitoria de Cultura e Extensão Universitária

Curso de curta duração em Análise elementar de tabelas 2x2. (Carga horária: 20h).

Faculdade de Saúde Pública, FSP, Brasil

Bolsista do(a): Pró-Reitoria de Cultura e Extensão Universitária

Curso de curta duração em Triagem Nutricional. (Carga horária: 4h).

Equipe Multiprofissional de Terapia Nutricional - Hospital das Clínicas, EMTNHC, Brasil

Métodos de Avaliação do Estado Nutricional. . (Carga horária: 4h).

Associação Paulista de Nutrição, APAN, Brasil

Atuação profissional

1. Universidade de São Paulo - USP

Vínculo institucional 
$2006-2009$

Vínculo: Aluno , Enquadramento funcional: Iniciação Científica , Carga horária: 20, Regime: Parcial

Outras informações:

Bolsista FAPESP. Projetos: Qualidade das refeições servidas em uma Unidade de Alimentação e Nutrição de uma indústria da região metropolitana de São Paulo; Impacto de uma intervenção para redução da DE de preparações servidas em uma UAN na qualidade global da refeição

$2006-2009$ Vínculo: Aluno, Enquadramento funcional: Aluno, Regime: Parcial

2. Faculdade de Saúde Pública - FSP

\section{Vínculo institucional}

2015 - 2015

2015 - 2015

2015 - 2015

2015 - 2015

2014 - 2014

2014 - 2014
Vínculo: Professor Visitante, Enquadramento funcional: Avaliação qualidade de cardápios e refeições , Carga horária: 8, Regime: Parcial

Vínculo: Bolsista , Enquadramento funcional: Programa de Aperfeiçoamento do Ensino - PAE , Carga horária: 6, Regime: Parcial

Outras informações: Disciplina Gestão de Cardápios

Vínculo: Professor convidado , Enquadramento funcional: Aula Estudo dos padrões da dieta , Carga horária: 3, Regime: Parcial Vínculo: Professor convidado, Enquadramento funcional: Aula análise estudos epidemiológicos em dieta , Carga horária: 3, Regime: Parcial

Vínculo: Bolsista , Enquadramento funcional: Programa de Aperfeiçoamento do Ensino - PAE , Carga horária: 6, Regime: Parcial

Outras informações: Disciplina Administração de Unidades de Alimentação e Nutrição

Vínculo: Monitor, Enquadramento funcional: Inquéritos de Saúde - Curso Programa de Verão, Carga horária: 20, Regime: Parcial 
2014 - 2014

2013 - 2013

2012 - 2012

$2012-2012$
Vínculo: Professor convidado, Enquadramento funcional: Aula Gestão de Cardápios , Carga horária: 4, Regime: Parcial

Vínculo: Bolsista, Enquadramento funcional: Programa de Aperfeiçoamento do Ensino - PAE , Carga horária: 6, Regime: Parcial

Outras informações: Disciplina de estágio em Alimentação e Nutrição Institucional

Vínculo: Professor convidado, Enquadramento funcional: Aula Estudo dos Padrões da Dieta , Carga horária: 3, Regime: Parcial Vínculo: Bolsista , Enquadramento funcional: Programa de Aperfeiçoamento do Ensino, Carga horária: 6, Regime: Parcial

Outras informações: Disciplina de estágio em Alimentação e Nutrição Institucional

Vínculo: Bolsista , Enquadramento funcional: Programa de Aperfeiçoamento do Ensino - PAE , Carga horária: 6, Regime: Parcial

Outras informações: Disciplina Administração de Unidades de Alimentação e Nutrição

2010 - $2010 \quad$ Vínculo: monitor, Enquadramento funcional: monitor da dsciplina HNT 171 - Adm de UAN, Regime: Parcial

2009 - 2009

$2009-2009$

$2007-2010$

$2007-2007$ Vínculo: monitor, Enquadramento funcional: monitor disciplina HNT 203 - Ed Nutricional, Regime: Parcial Vínculo: monitor, Enquadramento funcional: monitor da dsciplina HNT 171 - Adm de UAN, Regime: Parcial Vínculo: Iniciação científica , Enquadramento funcional: Bolsista FAPESP , Carga horária: 40, Regime: Dedicação exclusiva Vínculo: estagiaria , Enquadramento funcional: CLINUT - Clínica de Atendimento Nutricional, Regime: Parcial

\section{Secretaria de Segurança Alimentar e Nutricional do município de Suzano - SESANA}


4. Associação Prato Cheio - APC

\section{Vínculo institucional}

2010 - 2010 Vínculo: estagiaria , Enquadramento funcional: estagiaria de nutrição , Carga horária: 30, Regime: Parcial

5. Instituto de Assistência Medica ao Servidor Público - IAMSPE

Vínculo institucional

2010 - 2010 Vínculo: estagiaria , Enquadramento funcional: estagiaria de nutrição , Carga horária: 30, Regime: Parcial

6. Empório Santa Clara Pão e Vinho LTDA - SNTA CLARA

\section{Vínculo institucional}

2006 - 2007 Vínculo: Estagiária , Enquadramento funcional: Estagiária em Nutrição, Carga horária: 30, Regime: Parcial

7. Centro de Referência a Prevenção Controle de Doenças Associadas a Nutrição CRNUTRI

Vínculo institucional 


\section{Projetos}

Projetos de pesquisaProjetos de pesquisa

2015 - Atual Estudo Longitudinal de Saúde do Adulto - ELSA: Avaliação do consumo e associações em desfechos de saúde. Situação: Em andamento Natureza: Projetos de pesquisa

Integrantes: Bartira Mendes Gorgulho; JOSIANE STELUTI; Aline Carvalho Martins; Dirce Maria Lobo Marchioni (Responsável); Roberta Oliveira Santos; Juliana Araújo Teixeira; Antonio Augusto Ferreira Carioca

\section{2 - Atual La Dieta}

Descrição: Este projeto trata da avaliação e desenvolvimento de metodologias de coleta e análise de dados dietéticos para obtenção de medidas acuradas do consumo de nutrientes e alimentos, visando o uso em estudos epidemiológicos. Será avaliado o desempenho de metodologia padronizada para coleta de dados em nível individual usando o método de curto prazo recordatório de 24 horas (R24h). Esta metodologia, traduzida na plataforma GloboDiet, anteriormente denominada EPIC-soft, desenvolvida pela Agencia Internacional para Pesquisa em Câncer inicialmente para o estudo de coorte EPIC e a versão brasileira está sendo preparada no estudo La Dieta-Brasil.

Situação: Em andamento Natureza: Projetos de pesquisa

Integrantes: Bartira Mendes Gorgulho; Eliseu Verly Jr; JOSIANE STELUTI; Dirce Maria Lobo Marchioni (Responsável); FISBERG, REGINA MARA; Rosangela Pereira; Rosely Sichieri; Nadia Slimani

Descrição: Projeto insere-se em um elenco de estudos que vêm sendo realizados no Estado de São Paulo por um grupo de pesquisadores das universidade públicas estaduais: USP, UNICAMP e UNESP e que inclui um inquérito de saúde realizado no Município de São Paulo em 2003, financiado pela Secretaria Municipal de Saúde de São Paulo. Os dados a serem coletados permitirão comparações com os resultados dos demais inquéritos bem como avaliar as mudanças ocorridas no Município de São Paulo nos últimos cinco anos. Todos os onquéritos incluíram informações solicitadas pelos 
gestores e de importância para as políticas públicas e para a gestão local de saúde. O inquérito a ser realizado conta com financiamento da Secretaria Municipal de Saúde de São Paulo. Estas pesquisas representam uma importante interface entre a epidemiologia e os serviços de saúde, e os bancos de dados existentes e vêm permitindo uma expressiva produção acadêmica na forma de monografias, dissertações, teses, trabalhos apresentados em eventos científicos e artigos em periódicos.

Situação: Concluído Natureza: Projetos de pesquisa

Integrantes: Bartira Mendes Gorgulho; Chester Luís Galvão Cesar (Responsável); Regina Mara Fisberg; Dirce Maria Lobo Marchioni; Sheila Rizzato; Camila Monteiro; Diva Aliete Santos; Cristiane Salles; Maria cecília Goi Porto Alves; Moisés Goldbaum; Marilisa Berti de Azevedo Barros

Financiador(es): Secretaria Municipal de Saúde de São Paulo-SMS/SP

$2006-2009$ Promoção da alimentação saudável no ambiente de trabalho: redução da densidade energética das refeições servidas em unidade de alimentação e nutrição

Descrição: Este projeto tem por objetivo desenvolver, aplicar e avaliar a metodologia de uma intervenção para a promoção da alimentação saudável, baseada na estratégia de redução da densidade energética de preparações servidas em restaurante institucional. O estudo será desenvolvido em Unidade de Alimentação e Nutrição, com aproximadamente 200 funcionários..

Situação: Concluído Natureza: Projetos de pesquisa

Alunos envolvidos: Graduação (2); Mestrado acadêmico (1);

Integrantes: Bartira Mendes Gorgulho; Marisa Lipi; Agatha Nogueira Previdelli; Dirce Maria Lobo Marchioni (Responsável)

Financiador(es): Conselho Nacional de Desenvolvimento Científico e Tecnológico-CNPq

\section{Revisor de periódico}

1. Cadernos de Saúde Pública (ENSP. Impresso)

2015 - Atual Regime: Parcial

2. Nutrire (São Paulo) 
Áreas de atuação

1. Alimentação coletiva

2. Padrão alimentar

3. Epidemiologia Nutricional

4. Saúde Coletiva

Idiomas

Alemão Compreende Pouco, Fala Pouco, Escreve Pouco, Lê Pouco

Inglês Compreende Bem, Fala Razoavelmente, Escreve Bem, Lê Bem

Prêmios e títulos

2015

Prêmio SBAN ILSI 2015, ILSI Brasil

Producão

Produção bibliográfica

Artigos completos publicados em periódicos

1. Gorgulho, B; POT, G. K.; SARTI, F. M.; MARCHIONI, D. M. L.

Indices for the assessment of nutritional quality of meals: a systematic review. British Journal of Nutrition. , v.115, p.2017 - 2024, 2016. 
2. B. Gorgulho; FISBERG, R.M.; MARCHIONI, D.M.L.

Away-from-home meals: Prevalence and characteristics in a metropolis. Revista de Nutrição (Impresso), , v.27, p.703 - 713, 2014.

3. GORGULHO, B. M.; FISBERG, R. M.; MARCHIONI, D. M. L.

Nutritional quality of major meals consumed away from home in Brazil and its association with the overall diet quality. Preventive Medicine (1972. Print). , v.57, p. 98 - 101, 2013.

4. MARCHIONI, DIRCE MARIA LOBO; MENDES, ALINE; GORGULHO, BARTIRA; STELLA, ROBERTA HORSCHUTZ; FISBERG, REGINA MARA

Densidade energética da dieta e fatores associados: como está a população de São Paulo?. Arquivos Brasileiros de Endocrinologia e Metabologia (Impresso). , v.56, p.638 - 645, 2012.

5. GORGULHO, B. M.; PREVIDELLI, A. N.; MARCHIONI, D.M.L.

Effects of an intervention in the workplace food environment. Nutrition \& Food Science. , v.42, p.156 $-163,2012$.

6. GORGULHO, B. M.; MARCHIONI, D.M.L.; CONCEIÇÃO, ADRIANA BAILAN; STELUTI, JOSIANE; MUSSI, MARINA; NAGAI, ROBERTA; Teixeira, LR; DA LUZ, ANDREA APARECIDA; FISCHER, FRIDA MARINA

Quality of diet of working college students. Work (Reading, MA), , v.41, p.5806 - 5809, 2012.

7. GORGULHO, B. M.; LIPI, M.; MARCHIONI, D.M.L.

Qualidade nutricional das refeições servidas em uma unidade de alimentação e nutrição de uma indústria da região metropolitana de São Paulo. Revista de Nutrição (Impresso). , v.24, p.463 - 472, 2011.

Artigos aceitos para publicação

1. GORGULHO, BARTIRA; POT, G. K.; SARTI, F. M.; FISBERG, R.M.; MARCHIONI, DIRCE MARIA LOBO

Measuring quality of main meals: development and validation of a meal quality index. British Journal of Nutrition. , 2016.

2. MARCHIONI, D. M. L.; B. Gorgulho; LIPI, M.; PREVIDELLI, A. N.

Energy density and diet quality among Brazilian workers. Nutrition \& Food Science., 2015.

3. MARCHIONI, D.M.L.; B. Gorgulho; VERLY JR, E.; FISBERG, R.M. 
Prevalência de omissão do café da manhã e seus fatores associados em adolescentes de São Paulo: estudo ISA-Capital. Revista da Sociedade Brasileira de Alimentação e Nutrição. , 2015.

\section{Capítulos de livros publicados}

1. FISBERG, R.M.; MARCHIONI, D.M.L.; B. Gorgulho; CASTRO, M. A.

Inquéritos Alimentares na População Brasileira In: Nutrição em Saúde Coletiva.1 ed. : Atheneu, 2014, v.1, p. 23-30.

2. GORGULHO, B. M.; VERLY JUNIOR, E.

Consistência dos dados dietéticos: Questionário de Frequência Alimentar - QFA In: Manual de avaliação do consumo alimentar em estudos populacionais: a experiência do inquérito de saúde em São Paulo (ISA). 1 ed.São Paulo : Editora da Faculdade de Saúde Pública, Universidade de São Paulo, 2012, v.1, p. 25-26.

Trabalhos publicados em anais de eventos (resumo)

1. SANTOS, R. O.; Gorgulho, B; MARCHIONI, D. M. L.; FISBERG, R.M.; Baltar, V. A ESCOLHA DA DEFINIÇÃO DE REFEIÇÃO PODE MUDAR O PERFIL DE NUTRIENTES DO ALMOÇO In: $13^{\circ}$ Congresso Nacional da Sociedade Brasileira de Alimentação e Nutrição, 2015, São Paulo. 13 $^{\circ}$ Congresso Nacional da Sociedade Brasileira de Alimentação e Nutrição. São Paulo: Nutrire, 2015. v.S.

2. Gorgulho, B; POT, G. K.; SARTI, F. M.; MARCHIONI, D. M. L. A SYSTEMATIC REVIEW ON INDICATORS OF MEAL QUALITY In: XVII Congresso Latinoamericano de Nutricion, 2015, Punta Cana, Rep Dominicana. XVII Congresso Latinoamericano de Nutricion. Archivos Latinoamericanos de Nutricion, 2015.

3. SANTOS, R. O.; Gorgulho, B; FISBERG, R.M.; MARCHIONI, D. M. L.; Baltar, V. COMPARISON BETWEEN TWO BREAKFAST DEFINITIONS: SELF-REPORT AND PERIOD OF THE DAY. ARE THEY PRODUCE THE SAME RESULT? In: XVII Congresso Latinoamericano de Nutricion, 2015, Punta Cana, Rep Dominicana. XVII Congresso Latinoamericano de Nutricion. Archivos Latinoamericanos de Nuricion, 2015.

4. Gorgulho, B; POT, G. K.; SARTI, F. M.; FISBERG, R.M.; MARCHIONI, D. M. L. Measuring quality of meals: development of an index to be used in multicultural context In: $12 \mathrm{~h}$ European Nutrition Conference, 2015, Berlin. 12h European Nutrition Conference. Annals of Nutrition and 
Metabolism, 2015. v.47S1.

5. Gorgulho, B; SANTOS, R. O.; Baltar, V; MARCHIONI, D. M. L. QUALIDADE DO ALMOÇO DOS BRASILEIROS: UMA ABORDAGEM MULTINÍVEL In: $13^{\circ}$ Congresso Nacional da Sociedade Brasileira de Alimentação e Nutrição, 2015, São Paulo. 13 $^{\circ}$ Congresso Nacional da Sociedade Brasileira de Alimentação e Nutrição. São Paulo: Nutrire, 2015. v.S.

6. Gorgulho, B; SANTOS, R. O.; Baltar, V; FISBERG, REGINA MARA; MARCHIONI, D.M.L. THE CHOICE OF DINNER DEFINITION CAN CHANGE THE NUTRIENT PROFILE In: 12th European Nutrition Conference, 2015, Berlin. 12th European Nutrition Conference. Annals of Nutrition and Metabolism, 2015. v.67S1.

7. Gorgulho, B; FISBERG, R.M.; MARCHIONI, D.M.L. Lunch consumed away from home in the city of São Paulo, Southeast Brazil In: $20^{\circ}$ World Congress of Epidemiology, 2014, Anchorage. $\mathbf{2 0}^{\circ}$ World Congress of Epidemiology. IEA, 2014.

8. Silva, F. F.; B. Gorgulho; MARCHIONI, D. M. L. Qualidade da dieta: da adolescência a vida adulta In: 22 simpósio Internacional de Iniciação e Tecnologia da USP, 2014, São Paulo. 22 simpósio Internacional de Iniciação e Tecnologia da USP. , 2014.

9. GORGULHO, B. M.; Silva, F. F.; FISBERG, R. M.; MARCHIONI, D. M. L. Alimentação fora do lar e sua relação com a qualidade da dieta de moradores do município de São Paulo: estudo ISAcapital In: $12^{\circ}$ Congresso Nacional da Sociedade Brasileira de Alimentação e Nutrição, 2013, Foz do Iguaçu. $1^{\circ}$ Congresso Nacional da Sociedade Brasileira de Alimentação e Nutrição. SBAN, 2013.

10. Silva, F. F.; GORGULHO, B. M.; FISBERG, R.M.; MARCHIONI, D. M. L. Qualidade da refeição de adolescentes residentes no município de São Paulo: Estudo ISA-Capital. In: $3^{\circ}$ Simpósio Aprender com Cultura e Extensão, 2013, Ribeirão Preto. $3^{\circ}$ Simpósio Aprender com Cultura e Extensão. , 2013.

11. Silva, F. F.; GORGULHO, B. M.; FISBERG, R.M.; MARCHIONI, D. M. L. Qualidade da refeição de jovens residentes no município de São Paulo: Estudo ISA-Capital In: $12^{\circ}$ Congresso Nacional da Sociedade Brasileira de Alimentação e Nutrição, 2013, Foz do Iguaçu. 12 $^{\circ}$ Congresso Nacional da Sociedade Brasileira de Alimentação e Nutrição. SBAN, 2013.

12. Mendes, A; Martins, AC; de Castro MA; GORGULHO, B. M.; FISBERG, R.M.; MARCHIONI, D.M.L. ENERGY DENSITY AND CARDIOVASCULAR RISK FACTORS IN THE POPULATION OF SÃO PAULO In: INTERNATIONAL CONFERENCE ON DIT AND ACTIVITY METHODS, 2012, ROMA. ABSTRACT BOOK. ROMA: FAO, 2012. p.120 - 121

13. GORGULHO, B. M.; Avelino, G; Valentine, P; FISBERG, R.M.; MARCHIONI, D.M.L. OUTOF-HOME EATING PREVALENCE IN THE CITY OF SÃO PAULO, SOUTHEAST BRAZIL In: INTERNATIONAL CONFERENCE ON DIT AND ACTIVITY METHODS, 2012, ROMA. 
ABSTRACT BOOK. ROMA: FAO, 2012. p.46 - 46

14. PREVIDELli, A. N.; ANDRADE, S. C.; GORGULHO, B. M.; VERLY JR, E.; MARCHIONI, D.M.L. Population's distribution scores of brazilian healthy eating index - revised components estimated by usual dietary intake among adolescents of São paulo, Brazil In: XVI Congresso Latinoamericano de Nutrição, 2012, Havana. SLAN. , 2012.

15. GORGULHO, B. M.; CASTRO, M. A.; FISBERG, R. M.; MARCHIONI, D. M. L. Quality of the meals consumed out of home in the city of São Paulo, southeast Brazil In: XVI Congresso Latinoamericano de Nutrição, 2012, Havana. SLAN. Havana: , 2012.

16. VERLY JR, E.; GORGULHO, B. M.; Avelino, G; Mendes, A; FISBERG, R.M.; MARCHIONI, D.M.L. THE USE OF AN INDICATOR VARIABLE RATHER THAN AN FFQ CAN BE USED TO ESTIMATE USUAL INTAKE OF FOOD EPISODICALLY CONSUMED In: INTERNATIONAL CONFERENCE ON DIT AND ACTIVITY METHODS, 2012, ROMA. ABSTRACT BOOK. , 2012. p. $232-232$

17. Avelino, G; de Castro MA; GORGULHO, B. M.; Baltar, V; MARCHIONI, D.M.L.; FISBERG, R.M. UNDERREPORTING OF ENERGY INTAKE IN ADULTS AND ELDERLY RESIDING IN THE CITY OS SÃO PAULO, BRAZIL In: INTERNATIONAL CONFERENCE ON DIT AND ACTIVITY METHODS, 2012, ROMA.ABSTRACT BOOK. ROMA: FAO, 2012. p.137 - 138

18. Martins, AC; SELEM, S. C.; CARLOS, JAQUELINE VENANCIO; B. Gorgulho; FISBERG, R.M.; MARCHIONI, DIRCE MARIA LOBO. Consumo excessivo de carnes vermelhas e processadas em São PAulo In: $11^{\circ}$ Congresso da Sociedade Brasileira de Alimentação e Nutrição, 2011, Fortaleza. $1^{\circ}$ Congresso da Sociedade Brasileira de Alimentação e Nutrição. São Paulo: Nutrire, 2011.

19. CARLOS, JAQUELINE VENANCIO; PREVIDELli, A. N.; GORGULHO, B. M.; MARCHIONI, D.M.L. Diet quality of male adult participants HIM study-Brazil (Natural History of HPV infection in men) multicentric study In: World Congress of Epidemiology, 2011, Edinburgh. Journal of Epidemiology \& Community health. , 2011. v.65. p.a130 - a130

20. CARVAlHO, Aline MARTINS; VERLy JR, E.; PREVIDELli, A. N.; GORGULHO, B. M.; MARCHIONI, D.M.L.; FISBERG, R.M. Processed meat consumed by brazilian adolescents: an analysis according to traffic light labelling In: World Congress of Epidemiology, 2011, Edinburgh. Journal of Epidemiology \& Community health. , 2011. v.65. p.a429 - a429

21. B. Gorgulho; MARCHIONI, D.M.L.; STELUTI, JOSIANE; CONCEIÇÃO, ADRIANA BAILAN; MUSSI, MARINA; NAGAI, ROBERTA; DA LUZ, ANDREA APARECIDA; FISCHER, FRIDA MARINA. Qualidade da dieta de jovens trabalhadores no município de São Paulo In: $11^{\circ}$

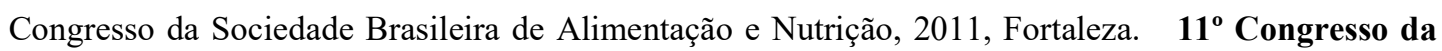
Sociedade Brasileira de Alimentação e Nutrição. Sao Paulo: Nutrire, 2011.

22. BRUNACIO, KAROLINE HONORATO; VERLY JR, E.; PIOVEZAN, LIVIA GONÇALVES; 
BIGIO, ROBERTA SCHEIN; GORGULHO, B. M.; cesar, C.L.G.; FISBERG, R.M.; MARCHIONI, D.M.L. USO DE SUPLEMENTOS DIETÉTICOS ENTRE RESIDENTES DO MUNICÍPIO DE SÃO PAULO In: $11^{\circ}$ CONGRESSO NACIONAL DA SOCIEDADE BRASILEIRA DE ALIMENTAÇÃO E NUTRIÇÃO, 2011, FORTALEZA - CE. $\quad$ 11 $^{\circ}$ CONGRESSO NACIONAL DA SOCIEDADE BRASILEIRA DE ALIMENTAÇÃO E NUTRIÇÃO., 2011.

23. SElem, S. C.; de Castro MA; CARlos, JAQUeline VEnANCIO; GORGULhO, B. M.; MARCHIONI, D.M.L.; FISBERG, R.M. Validity of self-reported hypertension among brazilian adults In: World Congress of Epidemiology, 2011, Edinburgh. Journal of Epidemiology \& community health., 2011. v.65. p.A130 - A130

24. PREVIDELLI, A. N.; VERLY JR, E.; CARLOS, JAQUELINE VENANCIO; GORGULHO, B. M.; MARCHIONI, D.M.L. VARIAÇÃO TEMPORAL DA QUALIDADE DA DIETA DE UMA COORTE DE ADOLESCENTES RESIDENTES NO MUNICÍPIO DE SÃO PAULO In: $11^{\circ}$ CONGRESSO NACIONAL DA SOCIEDADE BRASILEIRA DE ALIMENTAÇÃO E NUTRIÇÃO, 2011, FORTALEZA- CE. $\mathbf{1 1}^{\circ}$ CONGRESSO NACIONAL DA SOCIEDADE BRASILEIRA DE ALIMENTAÇÃO E NUTRIÇÃO., 2011.

25. GORGULHO, B. M.; PREVIDELLI, A. N.; MARCHIONI, D.M.L. Impacto de uma intervenção nutricional em ambiente de trabalho na qualidade da refeição In: II World Congress of Public Health Nutrition and I Latin American Congress of Community Nutrition, 2010, Porto. Public Health Nutrition (Wallingford). , 2010. v.13.

26. GORGULHO, B. M.; LIPI, M.; MARCHIONI, D.M.L. Características das refeições servidas em uma Unidade de Alimentação e Nutrição de uma indústria da região metropolitana de São Paulo In: $17^{\circ}$ Simpósio Internacional de Iniciação Científica da USP, 2009, Ribeirão Preto. $17^{\circ}$ Simpósio Internacional de Iniciação Científica da USP. , 2009.

27. GORGULHO, B. M.; LIPI, M.; MARCHIONI, D.M.L. Principais caracteristicas das refeições servidas em uma unidade de alimentação e nutrição de uma industria da região metropolitana de São Paulo In: $10^{\circ}$ Congresso Nacional da Sociedade Brasileira de Alimentação e Nutrição, 2009, São Paulo. Nutrire., 2009.

28. GORGULHO, B. M.; LIPI, M.; MARCHIONI, D.M.L. Qualidade das refeições servidas em uma Unidade de Alimentação e Nutrição de uma industria da região metropolitana de São Paulo In: $140^{\circ}$ Congresso Nacional da Sociedade Brasileira de Alimentação e Nutrição, 2009, São Paulo. Nutrire. , 2009.

29. VERLY JR, E.; GORGULHO, B. M.; cesar, C.L.G.; FISBERG, R.M.; MARCHIONI, D.M.L. Atividade Física e Hábitos de Vida de Adolescentes residentes no Município de São Paulo In: XVIII Congresso Mundial de Epidemiologia e VII Congresso Brasileiro de Epidemiologia, 2008, Porto Alegre. XVIII Congresso Mundial de Epidemiologia e VII Congresso Brasileiro de Epidemiologia. , 2008. 
30. GORGULHO, B. M.; VERLY JR, E.; cesar, C.L.G.; FISBERG, R.M.; MARCHIONI, D.M.L. Estado Nutricional e Insatisfação Corporal entre Adolescentes Residentes no Município de São Paulo. In: XVIII Congresso Mundial de Epidemiologia e VII Congresso Brasileiro de Epidemiologia, 2008, Porto Alegre. XVIII Congresso Mundial de Epidemiologia e VII Congresso Brasileiro de Epidemiologia. , 2008.

31. GORGULHO, B. M.; MARCHIONI, D.M.L. Qualidade das refeições servidas em uma unidade de alimentação e nutrição de uma indústria da região metropolitana de São Paulo In: $16^{\circ}$ Simpósio Internacional de Iniciação Científica da USP, 2008, Ribeirão Preto. 16 $^{\circ}$ Simpósio Internacional de Iniciação Científica da USP. , 2008.

Apresentação de trabalho e palestra

1. Gorgulho, B; MARCHIONI, D.M.L. Definição e visão geral dos métodos para identificação de padrões alimentares, 2015. (Conferência ou palestra,Apresentação de Trabalho) 2. Gorgulho, B; Mendes, A. Índice de qualidade da dieta revisado e índice de qualidade da refeição, 2015. (Conferência ou palestra,Apresentação de Trabalho)

3. GORGULHO, B. M.; Silva, F. F.; FISBERG, R.M.; MARCHIONI, D. M. L. Alimentação fora do lar e sua relação com a qualidade da dieta de moradores do município de São Paulo: Estudo ISA-Capital., 2013. (Congresso,Apresentação de Trabalho)

4. GORGULHO, B. M.; Avelino, G; Valentine, P; FISBERG, R.M.; MARCHIONI, D.M.L. OUTOF-HOME EATING PREVAlENCE IN THE CITY OF SÃo PAUlo, SOUTHEAST BRAZIL, 2012. (Conferência ou palestra,Apresentação de Trabalho)

5. GORGULHO, B. M.; MARCHIONI, D.M.L.; STELUTI, JOSIANE; CONCEIÇÃO, ADRIANA BAILAN; MUSSI, MARINA; NAGAI, ROBERTA; MATSUMURA, ROBERTO JUN; DA LUZ, ANDREA APARECIDA; FISCHER, FRIDA MARINA. QUALIDADE DA DIETA DE JOVENS TRABALHADORES NO MUNICÍPIO DE SÃO PAULO, 2011. (Congresso,Apresentação de Trabalho)

6. GORGULHO, B. M. Conjugando saberes e competências do nutricionista, 2009. (Simpósio,Apresentação de Trabalho)

7. GORGULHO, B. M.; VERLY JR, E.; cesar, C.L.G.; FISBERG, R.M.; MARCHIONI, D.M.L. Estado Nutricional e Insatisfação Corporal entre Adolscentes residentes no Município de São paulo, 2008. (Outra,Apresentação de Trabalho) 
1. MARCHIONI, D. M. L.; PHILIPPI, S. T.; FOCK, R. A.; ROGERO, M. M.; CASSANI, R. S. L.; CARIOCA, A. A. F.; Gorgulho, B; LEME, A. C.; STELUTI, JOSIANE; TEIXEIRA, J. A. $\mathbf{1 3}^{\circ}$ Congresso da Sociedade Brasileira de Alimentação e Nutrição, 2015. (Congresso, Organização de evento)

2. GORGULHO, B. M. Executiva Nacional dos Estudantes de Nutrição. XXVI Encontro Nacional dos Estudantes de Nutrição, 2009. (Outro, Organização de evento)

Outras informações relevantes

1 Classificada em segundo lugar no concurso público de provas e títulos para provimento de cargos da carreira do magistério superior na Universidade Federal do Mato Grosso, edital número 10/PROAD/SGP/2015, área do conhecimento nutrição, sub área do conhecimento Gestão em Unidade de Alimentação e Nutrição; Alimentação Coletiva. 